\title{
Beyond Two Cold War Blocs: \\ Canadian Involvement in the Peruvian Socialist \\ Nexus, 1960-1975
}

\author{
by
}

Gillian Gibson

A thesis submitted to the Faculty of Graduate and Postdoctoral Affairs in partial fulfillment of the requirements for the degree of

Master of Arts

in

History

\section{Carleton University \\ Ottawa, Ontario}

(C) 2012

Gillian Gibson 
Library and Archives

Canada

Published Heritage

Branch

395 Wellington Street

Ottawa ON K1A ON4

Canada
Bibliothèque et

Archives Canada

Direction du

Patrimoine de l'édition

395 , rue Wellington

Ottawa ON K1A ON4

Canada
Your file Votre référence

ISBN: 978-0-494-93560-6

Our file Notre référence

ISBN: $978-0-494-93560-6$
NOTICE:

The author has granted a nonexclusive license allowing Library and Archives Canada to reproduce, publish, archive, preserve, conserve, communicate to the public by telecommunication or on the Internet, loan, distrbute and sell theses worldwide, for commercial or noncommercial purposes, in microform, paper, electronic and/or any other formats.

The author retains copyright ownership and moral rights in this thesis. Neither the thesis nor substantial extracts from it may be printed or otherwise reproduced without the author's permission.
AVIS:

L'auteur a accordé une licence non exclusive permettant à la Bibliothèque et Archives Canada de reproduire, publier, archiver, sauvegarder, conserver, transmettre au public par télécommunication ou par l'Internet, prêter, distribuer et vendre des thèses partout dans le monde, à des fins commerciales ou autres, sur support microforme, papier, électronique et/ou autres formats.

L'auteur conserve la propriété du droit d'auteur et des droits moraux qui protege cette thèse. $\mathrm{Ni}$ la thèse ni des extraits substantiels de celle-ci ne doivent être imprimés ou autrement reproduits sans son autorisation.
In compliance with the Canadian Privacy Act some supporting forms may have been removed from this thesis.

While these forms may be included in the document page count, their removal does not represent any loss of content from the thesis.
Conformément à la loi canadienne sur la protection de la vie privée, quelques formulaires secondaires ont été enlevés de cette thèse.

Bien que ces formulaires aient inclus dans la pagination, il n'y aura aucun contenu manquant. 
The Department of History recommends to the Faculty of Graduate and Postdoctoral Affairs acceptance of the thesis

\title{
Beyond Two Cold War Blocs:
}

Canadian Involvement in the Peruvian Socialist Nexus, 1960-1975

\author{
submitted by \\ Gillian Gibson, B.A. Hons.
}

in partial fulfilment of the requirements

for the degree of Master of Arts

Sonya Lipsett-Rivera, Thesis Supervisor

James D. Miller, Chair

Department of History

Carleton University

26 September 2012 


\begin{abstract}
This thesis explores the participation of NGOs, specifically Oxfam, and various NSAs in the Peruvian socialist nexus throughout the 1960s until 1975. This moves beyond traditional Cold War studies as it approaches inter-state relations from a nongovernmental perspective. This leads to many questions regarding attitudes during this period and suggests that there was space for leftist activities in Western aligned countries during the Cold War at the international level.
\end{abstract}


Acknowledgements

The completion of this thesis would not have been possible without the assistance of various individuals and institutions. I would first like to thank my supervisor, Sonya Lipsett-Rivera, for her support, advice, encouragement, and patience. I am also grateful to my committee members. Norman Hillmer, Peter Gose, and David Dean have provided invaluable insight, support and constructive criticism. All errors are mine alone.

I am indebted to the History Department and the Faculty of Graduate and Postdoctoral Affairs at Carleton University for the financial assistance that they have extended to me. Without the granted funds for travel, research, and writing this would not have been possible. I am especially grateful to Joan White for all of the technical assistance that she has provided. Thank you to the numerous staff at Library and Archives Canada who have aided in and facilitated my research.

Numerous people encouraged me to pursue my Masters. For this I am thankful to Christine Rivas, Aleksandra Bennett, and Pauline Rankin. Without their words of wisdom and guidance this would not have been possible. Similarly, thank you to Hugo Blanco for motivating me to complete this thesis and his kind words.

I wish to offer my deepest thanks to Monica Gonzalez for her assistance with translation, editing, and never ending support and encouragement in many and various ways. I would also like to similarly thank Matías Muñoz for his advice, encouragement, and for always pushing me to go further, and Ian Wereley for leading the way and letting me know what to expect. You have all been wonderful friends and an invaluable source of support.

I am eternally thankful to my family for their unconditional love and support. My mother, Patricia Gibson, father, William Gibson, and siblings, Jody Sack, Nicole, and Colin Gibson have all contributed to the successful completion of this study in their own unique way. You have always believed in me and I thank you for all that you have done.

Finally, I am especially grateful to Nick Shore for his patience and enduring belief in me. His constant words of encouragement and support have kept me calm when I have feared the worst possible outcome. For his numerous sacrifices and infinite love I am eternally grateful. 
Beyond Two Cold War Blocs:

Canadian Involvement in the Peruvian Socialist Nexus, 1960-1975

Table of Contents

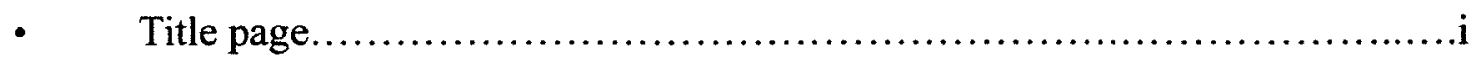

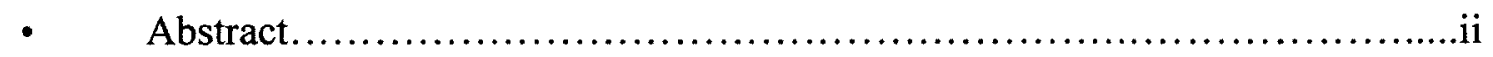

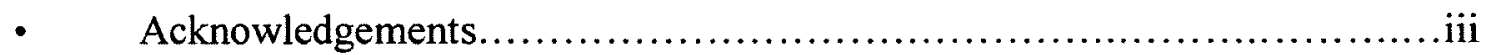

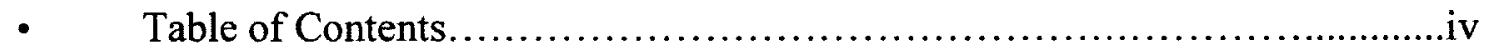

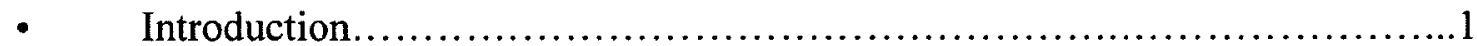

- Socialist Movements and the Cold War in Peru 1960-1975.................15

- Hugo Blanco and the events of 1961 in La Convención Valley, Peru........42

- Changes to the Canadian Political Landscape: The Pearson and Trudeau Years.................................................................

- Canadian NGOs and NSAs in the Peruvian Nexus.............................79

- Conclusion............................................................ 100

- $\quad$ List of Tables

- Table 1: Highlands, Peru: Estimated Values by Number and Surface of Agricultural Units by Economic Category for the Highlands,

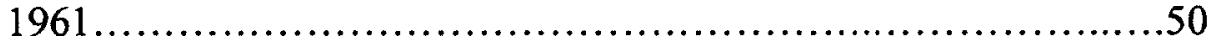

- Table 2: Aid to Latin America by Country and Category

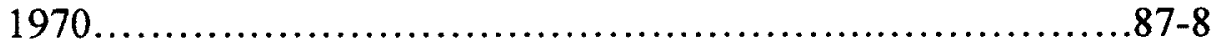

- List of Maps

- Map 1: Cuzco Region in Peru.....................................44

- Map 2: Geographic regions in Peru................................45

- List of Abbreviations............................................... 106

- Appendices

- Appendix I: Final Election Results Released by the National Election

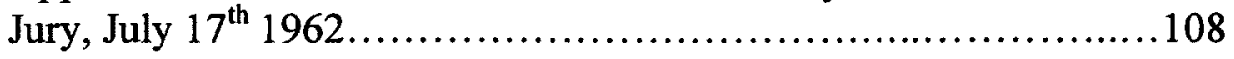

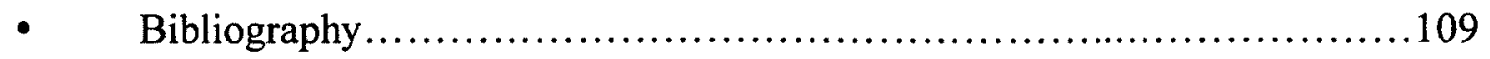




\section{Introduction}

There is an extensive body of literature that examines Cold War relations and ideologies. These studies typically divide the world into two spheres of influence: two hostile blocs that sought to impose their respective worldviews as the global ideological norm. The polarization of global relations throughout the decades of the Cold War leaves the impression that these two ideologies were mutually exclusive with respect to inter-state and economic relations. This thesis challenges this understanding of Cold War bipolarization by considering the role and activities of Canadian nongovernmental organizations (NGOs), non-state actors (NSAs), and unions in Peru. I explore the extent that they participated in socialist initiatives in Peru. In doing so, I argue that the contribution of Canadian NGOs, NSAs, and unions in Peru demonstrates how international involvement throughout the Cold War was far more complex than the traditional body of Cold War literature implies. While Canada is a Western country and was often aligned with the interests of the United States, during the Cold War, Canadian organizations actively participated within Peru's socialist nexus and conducted international projects that were similar to socialist state reforms being implemented at the time.

Various studies have considered the role of Canada in the Cold War but few have considered Canadian involvement in Peru with particular attention to NGOs and other nongovernmental associations such as unions. As will be demonstrated, developmental policies and ventures, by the 1960 s, were increasingly sought as a means to subvert the perceived communist threat. While this may have been true of governmental development organizations, I argue that outside of official government 
attempts, development did not conform to the perceived responsibilities of a Western ally. Rather, some projects, developed by organizations such as Oxfam, corresponded to the socialist context. These types of projects suggest that there was space for socialist activities at the international level even from states that maintained an anticommunist position.

Rather than emphasizing the ideological divide between Western and Communist powers vying to expand their global influence, Reginald Whitaker and Steve Hewitt point to variations and spaces in which certain left-leaning activities were tolerated in spite of their apparent contradiction of Western ideals. ${ }^{1}$ In fact, they argue that, while the Canadian government often catered to American interests, Canada increasingly continued to exert its own interests. ${ }^{2}$ This divergence from the Americans is particularly demonstrated by the shift in Canada's mentality after the Cuban Missile Crisis in 1962, at which time it increasingly became more common for the country to seek alternatives in the attempt to circumvent the potential for nuclear war. ${ }^{3}$ In the 1960s, for instance, Canadians saw an influx of left-leaning activities, with the rise in student protests, union activities and separatist movements, particularly in Quebec, with the Quiet Revolution in $1970 .{ }^{4}$ These activities and events point to a much more complex global situation that goes beyond the narrative

\footnotetext{
' Reg Whitaker \& Steve Hewitt, Canada and the Cold War, (Toronto, ON: James Lorimer \& Company Ltd., 2003).

${ }^{2}$ Ibid., 139. This, of course, very much depended upon the political party and the Prime Minister in

${ }^{2}$ Ibid., 139. This, of course, very much depended upon the political party and the Prime Minister in power.

${ }^{3}$ Ibid., 148.

${ }^{4}$ Various scholars have considered these movements. See for example Whitaker and Hewitt or Bryan D. Palmer, Canada's 1960s: The Ironies of Identity in a rebellious era, (Toronto, ON: University of Toronto Press, 2009).
} 
of the two contending ideologies, and provides a departure point for Canada and the Cold War internationally.

A review of the White Paper, Foreign Policy for Canadians, demonstrates that, by 1970 , Canada was, at least rhetorically, attempting to move beyond the traditional Cold War trajectory and assert its own interests. ${ }^{5}$ Moreover, by the 1970 s there increasingly was a cooling of international relations between the US and the USSR, or what is referred to as Détente. As inter-state relations began to moderate, Canada was better positioned to assert its own national interest. While the White Paper cannot, on its own, elucidate the path that Canadian foreign policy took, it confirms that international development was an increasingly popular model being used to move beyond traditional Cold War institutions. ${ }^{6}$ This emphasis on development is further demonstrated by the publication of The Pearson Report in $1969^{7}$ and the creation of the Canadian International Development Agency (CIDA) in $1966 .{ }^{8}$ While an examination of Canada's foreign policy review would render a more significant understanding of the country's actions in the international arena during this period, this type of analysis is inhibited by the limited accessibility to government documents for this time. Instead, an analysis of the actions taken by NGOs representing Canadian interests, specifically the projects and activities conducted by

\footnotetext{
${ }^{5}$ Mitchell Sharp, Department of External Affairs, "Foreign Policy for Canadians" in Foreign Policy for Canadians, (Ottawa, ON: Queens Printer, 1970). Throughout this paper there is the constant assertion that Canada is distinct from the United States.

${ }^{6}$ Jeremi Suri, "Non-Governmental Organizations and Non-State Actors," in Palgrave Advances in International History, ed. Patrick Finney (New York: Palgrave MacMillan, 2005): 239.

${ }^{7}$ Lester B. Pearson, Edward Boyle, Roberto de Oliveira Campos, C. Douglas Dillon, Wilfred Guth, W. Arthur Lewis, Robert E. Marjolin, Saburo Okita, Partners in Development: Report of the Commission on International Development (New York, NY: Praeger Publishers, 1969).

${ }^{8}$ Prior to 1966 international development was directed by the External Aid Office. For a comprehensive history of CIDA and its origins see: David R. Morrison, Aid and Ebb Tide, A History of CIDA and Canadian Development Assistance (Waterloo, ON: Wilfrid Laurier University Press in association with The North-South Institute, 1998).
} 
Oxfam Canada and various Canadian labour unions in Peru, will be used to form the basis of my thesis. The role of Canadian organizations and the Canadian context will be discussed in Chapter Three.

I argue that, through the international deployment of NGOs, Canada became an active participant in left-leaning initiatives on the international stage. My thesis is therefore intended to highlight the complexity of Cold War relations and the role of Canadian organizations beyond the official government position. Considering that the study of international relations during this period has mostly centered on realist assumptions that focused on the role of states as the main actors in the international sphere, there is often little attention paid to the role of non-state actors, such as NGOs, which, as will be demonstrated, can contribute to a deeper understanding of the Cold War global dynamic. As Jeremi Suri points out, this gap in the literature is especially significant, considering that in the 1960 s, as the world became embroiled in Cold War politics, NGOs were increasingly considered to be substitutes for Cold War institutions. ${ }^{9}$ An analysis that considers an alternative approach highlighting the relevance of NGOs and NSAs as prominent actors in this period is therefore needed.

Because the Cold War spanned nearly half a century and was characterized by a highly complex series of events that go beyond the scope of this paper, I will be exclusively focusing on the 1960 s and the early 1970 s. This timeframe is important, as in 1962 Cold War tensions reached unprecedented levels over the Cuban Missile Crisis (and the failed Bay of Pigs invasion in 1961) and continued to escalate throughout the decade. In addition, during the 1960s, debate over the war in Vietnam

\footnotetext{
${ }^{9}$ Jeremi Suri, "Non-Governmental Organizations and Non-State Actors," in Palgrave Advances in International History, ed. Patrick Finney (New York: Palgrave MacMillan, 2005): 239.
} 
sharpened as America became involved in a long and bitter war; in 1961 the Berlin Wall was erected, which came to represent the symbolic and physical barrier of the Iron Curtain; and the arms race reached new heights as the Soviet Union and United States continued to produce thousands of nuclear weapons. These events culminated in what is typically referred to as the height of the Cold War. ${ }^{10}$ Moreover, the $1960 \mathrm{~s}$ were tumultuous years in Canada, during which Canadian identity was reconfigured. ${ }^{11}$ This change is demonstrated through the increasing number of peace protests that were launched over the American involvement in Vietnam, various labour strikes, the Quebec separatist movement and Quiet Revolution, among others. $^{12}$

Situating the paper within this period, from the 1960 s to the mid 1970 s, my primary focus will be on the analysis of Canadian-Peruvian relations as represented by nongovernmental involvement, as Peru was considered a "neutral" country, given that it was not officially aligned with either bloc and was part of the Non-Aligned Movement (NAM). ${ }^{13}$ An examination of some events in Peru in the 1960 s provides an alternative to the narrative of two "polar" positions that is commonly advanced in the literature on the Cold War. Moreover, Peru has not been studied in great detail within the Cold War context. This lack of attention may be because it was not a strategically significant arena for Cold War politics; however, events in Peru during the Cold War reveal a variety of socialist actors on both the national and international

\footnotetext{
${ }^{10}$ See: Whitaker \& Hewitt, Canada and the Cold War or Robert Bothwell, The Big Chill: Canada and the Cold War, (Toronto, ON: Irwin Publishing 1998), 62-6.

${ }^{11}$ Palmer, Canada's 1960s.

12 Ibid., 21-22.

${ }^{13}$ This will be discussed in greater detail in subsequent chapter. Briefly, Peru was part of the NonAligned Movement that "was originally formed as a bloc of countries that would remain neutral during the Cold War." Eye on the UN. "Political Alliances in the UN." Accessed May 14, 2012, from: http://www.eyeontheun.org/view.asp?p=55\&l=11
} 
level. Further, Peru essentially straddled both of the Cold War blocs. First, Peru, as mentioned, was part of NAM, yet it is commonly asserted by scholars that it was aligned with the United States because Peru is situated within the American sphere of influence ${ }^{14}$ However, a closer examination of events in Peru suggests that it was a country with strong and influential leftist tendencies. Generally, at this time, Peru can be seen as pursuing a leftist agenda in spite of maintaining a "pro-American" stance ${ }^{15}$ (for example, it was part of the Alliance for Progress). The influence of the left in Peru, as will be discussed, greatly depended on who was governing the country. Furthermore, throughout the 1960 s there was a series of land reforms that would eventually radically alter how land was and is distributed in Peru. Hugo Blanco initiated this transition in 1962 in La Convención Valley, part of the Cusco district located in Southern Peru. Blanco is a veteran leader in peasant and indigenous rights and continues to campaign for these populations. After being exiled to Mexico, Chile, and Sweden, he returned to Peru and competed in the national elections, in which he won a seat in the national parliament in $1978 .^{16}$

In 1958 Blanco had moved to La Convención Valley from Buenos Aires, where he attended Argentina's Universidad de la Plata. He quickly became active in peasant politics by establishing unions, which pushed for the confiscation of land held by large estate owners, also known as haciendas, to be redistributed to the peasantry.

\footnotetext{
${ }^{14}$ For example see Jason Pribilsky, "Development and the "Indian Problem' in the Cold War Andes: Indigenismo, Science, and Modernization in the Making of the Cornell-Peru Project at Vicos," The Journal of the Society for Historians of American Foreign Relations, 33.3, (2009): 405-426. "In the period immediately following World War II, U.S.-specific interests in Peru took a backseat to concerns raised over Argentina as well as more hemispheric-wide security issues. With relative political stability, Peru conversely enjoyed strong economic and diplomatic ties with the United States," 408. ${ }^{15}$ Ibid.

${ }^{16}$ Robert Jackson Alexander, "Peruvian Trotskyism," in International Trotskyism, 1929-1985: A Documented Analysis of the Movement, (Durham, NC: Duke University Press, 1991): 645.
} 
During the time it took for this form of land holding to occur on a large scale, Blanco was persecuted for his actions and sentenced to death by the Peruvian military tribunal (a sentence that was eventually reversed). Blanco's work demonstrates that cooperative or "socialist" movements during and since the Cold War do not necessarily need to be launched through violent means in order to be successful, and that there is a need to distinguish between how these movements are organized and how they are carried out. Understanding the characteristics of the movements is particularly important when defining socialism and communism. Blanco is far removed from the Sendero Luminoso (Shining Path), an organized guerrilla group that operates through the use of force in Peru, and has received the majority of scholarly attention concerning leftist movements within the country. As Paul Navarro points out, hardly any attention has been given to left leaning movements in Peru beyond the Sendero. ${ }^{18}$ This has created the illusion that there were no other left inspired revolutionary campaigns present in Peru throughout the 1960s until the 1980 s. ${ }^{19}$ As will be demonstrated, there is a rich and complex story of the left that goes beyond the Sendero. ${ }^{20}$ Moreover, when these movements are considered, it is clear that the left in Peru was neither a cohesive nor a linear movement. As governments in Peru attempted to subvert these parties and movements, the left became fragmented, something which will be elaborated on in Chapter One. As this

\footnotetext{
${ }^{18}$ Paul Navarro, "A Maoist Counterpoint: Peruvian Maoism Beyond Sendero Luminoso," Latin American Perspectives, 37.1 (2010): 154.

${ }^{19}$ Ibid.

${ }^{20}$ The Sendero movement is, moreover, beyond the scope of this paper as they did not become highly active until the mid-1970s and 1980s, and will therefore only be referred to in passing. There is much scholarship on the Sendero for some studies see: Gorriti Ellenbogen, Gustavo. The Shining Path: $a$ history of the millenarian war in Peru. Chapel Hill, N.C.: University of North Carolina Press, (1999); or, Sergio Koc-Medard. Fragmented sovereignty: why Sendero Luminoso consolidated in some regions of Peru but not in others. Thesis Dissertation, Ottawa, ON (2005).
} 
occurred and the left movement became divided, the inception of what I will term a "socialist nexus" occurred.

The socialist nexus, while a local phenomenon, was not confined to national borders but was connected to the international realm. However, to trace and understand the complexity of the nexus, it is important to begin at the national level. By understanding how it operated in a national context, it can then be identified with other nations, thereby indicating the international scope of the nexus. The socialist nexus refers to ideologies, political and intellectual actors, who, despite often being at odds, were connected throughout the development of the Left both ideologically and politically. It is characterized by a myriad of actors and ideologies that, while distinct, comprised the Left. Participants in the nexus range from individuals or non-state actors (NSAs), government actors and organizations, to organizations such as NGOs and unions, to name a few. Participation in the nexus is not necessarily contingent on a conscious choice or declared affiliation with the Left, but rather can be determined through the intended and unintended consequences of action. This will be elaborated further and exemplified through Oxfam Canada's and labour unions' participation in the Peruvian socialist nexus.

Canadian NGOs became part of this nexus in Peru by the 1970 s. To understand how these NGOs, specifically Oxfam Canada, were connected to the left in Peru, Michael Jennings' idea of surrogacy of the state will be considered. ${ }^{21}$ Jennings argues that NGOs, while often considered to operate totally outside of the

\footnotetext{
${ }^{21}$ Michael Jennings, "Surrogates of the State? Non-Governmental Organisations and Development in Tanzania in the 1960s and 1970." African Studies Seminar. (Centre for Development Studies, Swansea University, 2006): 3. Accessed January 25, 201 1, from: http://www.ascleiden.nl/Pdf/paperjennings.pdf.
} 
state apparatus, are in fact influenced by the "periphery."22 By 1970, Peru was governed by a leftist military junta, headed by General Juan Velasco Alvarado. He undertook numerous reform projects, including sweeping land reforms whereby haciendas were expropriated and distributed into cooperatives. Cooperative structures were not only being set up by Peruvian locals and government, but by Canadian organizations as well. ${ }^{23}$ While the cooperatives were set up by various actors such as the local government, through grassroots initiatives such as Blanco's, or NGOs such as Oxfam, they are, by their very nature, politically left of center as they seek to socialize the means of production. ${ }^{24}$ While there were various motives, structures, and outcomes of the cooperative attempts, they all share the common trait of being a socialist institution in that they all sought to change the nature of land ownership from private property to a system where access, rights and obligations were shared among the community that belonged to the cooperative.

Oxfam Canada conducted development projects in Peru, which mirrored the policies being implemented by Velasco Alvarado and utilized Peruvian state institutions such as the Rural Development Bank. The extent to which Oxfam was influenced by the periphery will be considered in some detail in Chapter Three, in an attempt to demonstrate that Oxfam's participation in socialist activities in Peru places the organization within the socialist nexus in the 1970s. This is not to overemphasise the agency and/or the importance of Oxfam, but is intended as a case study on the

\footnotetext{
${ }^{22}$ Ibid.

${ }^{23}$ Canada was not the only country active in setting up cooperatives at this time. The United Kingdom, specifically, Scotland set up the first international cooperative in the region, which is still active today: Equal Exchange. I have tried on numerous occasions to make contact with Equal Exchange, but they have not responded to any of my requests to view their archival material on this cooperative.

${ }^{24}$ Tom Brass, "How agrarian cooperatives fail: Lessons from 1970s Peru," Journal of Peasant Studies, 34.2 (2007): 240-287. doi 10.1080/03066150701516690.
} 
role of NGOs more generally. While there were various other NGOs present in Peru, access to their archival material has not been possible. Additional support for the hypothesis that Canadian actors engaged in the Peruvian socialist nexus derives from the participation of Canadian unions and institutions in their advocacy for the release of Hugo Blanco. The extension of international support for a fundamental socialist actor further connects Canada to the socialist landscape of Peru.

There is much debate about how to define socialism. Latin American socialists, such as Blanco, call for a dramatic change in the form of government and dismantling of the capitalist structure. ${ }^{25}$ For the purposes of this thesis socialism refers to the political and social ideology that positions itself in opposition to capitalist structures and policies. Whereas capitalism is concerned with individual rights and relies upon the ownership of private property, socialism is centrally concerned with communal rights or what is referred to as the commune. Socialism will be used in this thesis since the Peruvian actors who will be considered identified themselves as such. Since this thesis considers Blanco and his movement within the socialist context in Peru during the Cold War, his conception of socialism,

\footnotetext{
${ }^{25}$ Blanco declares this is almost all interviews and lectures. See bibliography under Blanco. More recently Blanco identifies himself as being an ecosocialist For example see his statement on defining ecosocialism. "Hugo Blanco on 'ecosocialism' and indigenous struggles." Climate and Capitalism. (2009) Accessed May 15, 2012 from: http://climateandcapitalism.com/2009/02/16/hugo-blanco-onecosocialism-and-indigenous-struggles/ Additionally, in an interview in 2011 Blanco asserts that he changed from being a Trotskyist to ecosocialist because: "A traditional Marxism that doesn't support ecological protection belongs to a different and less enlightened era. This is why, though we keep calling ourselves Marxists, Trotskyists, Leninists, I dislike the expectation of full identification, because these are not religions. We have no Bible like we have no God. Don' $t$ forget that every word Marx or Trotsky wrote was contextually specific. Trotskyism was a deliberate and specific stand against Stalinism. After the putrefaction of the Stalinist state, why the devil should I remain Trotskyist? We don' $t$ need Trotskyists now; we need action-based, anti-capitalists. In Europe, we call ourselves ecosocialists; here, we call ourselves what we have always called ourselves, and believe what indigenous peoples have always believed." Hugo Blanco, interview by Alan Ramón Ward. "An Interview with Hugo Blanco Glados," Interventions: International Journal of Postcolonial Studies, 13.4, (December 8, 2011): 662. Accessed June 11, 2012 from: http://www.ww4report.com/node/7756
} 
specifically Trotskyism, will be considered in some detail. ${ }^{28}$

Leon Trotsky developed Trotskyism in response to Stalinism and Leninism and was greatly influenced by his experience in revolutionary Russia and his exile in Mexico in $1937 .{ }^{31}$ While Trotsky advanced numerous concepts and theories pertaining to revolution, only two will be discussed here, as the rest go beyond the scope of this thesis. The first is the idea of permanent revolution, while the second is what Trotsky termed 'dual power.' Generally, Trotskyists view the path to socialism through continuous revolution. Trotsky proposed that revolution would not remain at the national level, but rather that it would expand into other countries. As he states in The Theory of Permanent Revolution: "A national revolution is not a self-contained whole; it is only a link in the international chain. ${ }^{32}$ The revolution, should it be isolated to one country, would not be able to withstand the pressure of capitalist states unless other countries followed in the socialist revolution. Additionally, he asserts that the democratic stage is transitory, and that only through the development of socialism could a society enter into: "a permanent state of revolutionary development." ${ }^{33}$ The idea of permanent revolution had particular resonance in Latin America. ${ }^{34}$

\footnotetext{
${ }^{28}$ The socialist movements since the 1960 s have evolved into what is now termed 'ecosocialism.' In Peru, and Latin America ecosocialism is inherently concerned with indigenous rights and Pachamama (Mother Earth). Ian Agnus defines ecosocialism as an attempt: "to unite the best of the green and the red while overcoming the weaknesses of each. It tries to combine Marxism's analysis of human society with ecology's analysis of our relationship to the rest of nature." Ian Agnus. "How to make an Ecosocialist Revolution." Climate Change, Social Change, conference in Melbourne Australia, Oct. 2011. Victorian Trades Hall. Accessed May 15, 2012 from: http://climateandcapitalism.com/2011/10/07/how-to-make-an-ecosocialist-revolution/

${ }^{31}$ Ronald H. Chilcote, "Trotsky and Development Theory in Latin America" Critical Sociology 35.6: 720, doi: 10.1177/0011392109343058.

${ }^{32}$ Leon Trotsky, "The Theory of Permanent Revolution," Isaac Deutscher (ed.) The Age of Permanent Revolution, (Dell: New York, NY, 1964): 65.

${ }^{33}$ Ibid., 63-4.

${ }^{34}$ Ibid.
} 
One of the principal actors in the proliferation of Trotskyism in Peru was Blanco. His movement in La Convención, while repressed, reveals that Peruvian Trotskyists were able to incorporate the needs of the masses into a strategy to mobilize them. This notion is in contrast to guerrilla attempts that were confrontational strategies, and which were modeled after those employed in the Cuban Revolution. ${ }^{35}$ The method employed by Blanco, as opposed to guerrilla warfare, is important as it distinguishes the movement in La Convención from other revolutionary attempts across Latin America.

The second Trotskyist idea that Blanco employed was dual power, which refers to the point at which new political actors challenge the traditional power structure. In addition, dual power is situated in the prerevolutionary stage and as such is transitory. Trotsky states:

The historic preparation of a revolution brings about, in the prerevolutionary period, a situation in which the class which is called to realize the new social system, although not yet master of the country, has actually concentrated in its hands a significant share of state power, while the official apparatus of the government is still in the hands of the old lords. ${ }^{36}$

This transitory stage is highly unstable as actors on each side struggle for power. As such, the existence of dual power cannot last as either the revolution will succeed or be repressed. In La Convención, the revolution was largely successful to the extent that: "the landlord was ordered to hand over his keys and disappear into another zone." ${ }^{37}$ The methodology that Blanco used in La Convención to establish dual power further demonstrates that he did not employ guerrilla tactics. Blanco's ability to rouse

\footnotetext{
${ }^{35}$ Chilcote, "Trotsky and Development Theory," 728.

${ }^{36}$ Leon Trotsky, "Dual Power," in History of the Russian Revolution, trans. Max Eastman, (London: Victor Gollancz Limited, 1965): 224.

${ }^{37}$ Blanco, Land or Death, 61 .
} 
the masses through strikes and work stoppages (tactics used frequently by Blanco and his followers) led to the creation of dual power. Blanco spends a considerable amount of time defining and describing how dual power applied to Peru. He claims that the decrees issued by himself and his followers: "were instruments for raising consciousness, ${ }^{38}$ and not violent strategies.

While Trotsky maintained that a socialist revolution could only occur through armed struggle, such tactics were only a phase, and in the case of Peru, Blanco insisted that the peasantry had alternative legal mechanisms that could be employed until violence was initiated by the state. He states: "In countries like Peru, the masses still have access to a wide range of activities other than military." ${ }^{39}$ The use of violence should exclusively occur when: "the government...[was] obliged to cast off its legalistic mask and openly employ violence in defense of the system of exploitation." ${ }^{.40}$ Only when violence was initiated against the peasantry does Blanco argue that there remained no option other than armed struggle. ${ }^{41}$ The insistence on employing tactics other than violent means reveals that Blanco was not a guerrilla fighter who led an armed rebellion, but rather a leader who was able to organize and implement a revolutionary movement.

Given Blanco's adherence to Trotsky's conception of revolution, socialism will be the predominant term used to refer to the movements undertaken in Peru in the 1960s and 1970s. In this thesis, I will closely examine the growth of socialist thought in Peru in order to establish and to contextualize the socialist nexus in the

\footnotetext{
${ }^{38}$ Ibid.

${ }^{39}$ Ibid., 63.

${ }^{40}$ Ibid.

${ }^{41}$ Ibid.
} 
country. Doing so demonstrates that the left in Peru was highly fluid and factionalized. Furthermore, by establishing the socialist nexus in Peru, it will become possible to locate Canadian organizations and unions within the nexus and establish the extent of their involvement. Subsequently, I will provide a case study on Hugo Blanco, as he was a significant actor within the 1960s and is still an active peasant and indigenous rights leader. He is remembered as both a hero and a criminal, depending on who is asked. It is important to consider the reasons for his arrest and the subsequent international movement to free him in order to establish why international organizations intervened to free him.

Finally, a review of the Canadian context during the period will be made to establish the evolving role of international development as viewed by Canadians in the Cold War. Once the Canadian context for development has been established, Oxfam Canada's projects and correspondence with the Canadian government will be considered, in addition to the advocacy of Canadian unions and organizations for freeing Blanco. By considering the role that Canadian NGOs and unions played in Peru by the 1960s, it is possible to place Canadian actors in the socialist nexus of Peru, thereby pointing to the complexity of Cold War relations beyond that of two Cold War blocs and nation-state relations. The Cold War narrative of East versus West should not only be understood as the inter-state global dynamic of the time. It should also be understood as a time where international relations were contradictory and highly complex, as Canadian NGOs and NSAs, from a Western allied country, were actively supporting socialist activities in Peru in the 1970s. 
Socialist movements and the Cold War in Peru, 1960-1975

There were strong socialist tendencies across Latin America throughout the Cold War, which were mainly manifested among intellectuals and political thinkers. While Cold War studies typically divide countries and individual actors as either communist or anticommunist, the leftist current in Peru demonstrates that these categorizations are simplistic. Rather, a closer examination of socialist movements illustrates that these factions were highly complex and fluid and did not consist of a single cohesive phenomenon. This chapter establishes the socialist context in Peru, in which Canadian NGOs participated. As will be discussed, the Peruvian socialist nexus was characterized by ideological differences and political swings from the left to the right and vice versa. The variations of these movements exemplify the complexity of leftist movements and Cold War relations, which points to the necessity of re-examining global interactions during the Cold War. Dividing international associations into two polar blocs fails to fully capture the nexus of interaction not only between actors, but also within political and social movements.

Socialist movements and a variety of left-leaning initiatives were launched in Peru beginning in the early twentieth century. These Peruvian socialist movements were neither linear nor cohesive; rather they were diverse and often fractured as their actors and participants were frequently at odds. Moreover, and as will be discussed, these actors have significantly shifted from the far-left to the right, or somewhere in between. The leftist movements have also been intellectual, political, and/or revolutionary in their form. The history of socialist movements in Peru demonstrates the heterogeneous nature of political movements on a larger scale. In addition, within 
the political climate of the period, the prevalence and scale of these movements indicates that, while Peru faced increasing international pressure, particularly from the United States, socialist and communist tendencies were still vibrant and very much part of the country's social fabric. In addition, while US influence was present in Peru with the Americans closely monitoring communist activities, for the most part the US maintained a policy of non-intervention in Peru- unlike in Guatemala in 1954, Cuba in the 1960s, or the Dominican Republic in 1965.

Two men were responsible for the initial dissemination of communist and socialist ideas in Peru: a Marxist-Leninist, José Carlos Mariátegui (1894-1930), and Víctor Raúl Haya de la Torre (1895-1979), who, within his lifetime, changed his political alliances from the far left to a more conservative position. In 1928, Mariátegui, the first Peruvian communist intellectual, published Seven Interpretive Essays on Peruvian Reality ${ }^{43}$, a book which has had significant influence on socialist movements in Peru, and is still widely read across Latin America. This text stresses the importance of the ayllu (a basic Andean social and political unit based on lineage or kin groups) in the future institutionalization of socialism. ${ }^{44}$

Mariátegui also founded the Peruvian Socialist Party in 1928, (which, after his death, in 1930, became the Communist Party of Peru), and the first national labour union, the Confederación General de Trabajadores del Perú (General Confederation of Peruvian Workers- GCTP). ${ }^{45} \mathrm{He}$ initially worked with the Alianza Popular Revolucionaria Americana (American Popular Revolutionary Alliance - APRA) that

\footnotetext{
${ }^{43}$ José Carlos Mariátegui, Seven Interpretive Essays on Peruvian Reality, trans. Marjory Urquidi (Austin Texas: University of Texas Press, 1974).

${ }^{44}$ Ibid.

45 Thomas Angotti, "The Contributions of José Carlos Mariátegui to Revolutionary Theory," Latin American Perspectives, 49.14 (1989): 33-57.
} 
Haya de la Torre founded in Mexico, although Mariátegui eventually left the party because of conflicting ideologies, which will be discussed below. Mariátegui died at the age of 35 due to illness, but worked for numerous journals and newspapers within his short life, and founded several newspapers, such as Labor in $1928 .^{46}$

Haya de la Torre was also a leading Communist thinker and revolutionary in Peru. Brought up in Trujillo, on the Northern coast of Peru, Haya de la Torre witnessed: "first-hand the severe social dislocations produced by the foreigncontrolled sugar interest." ${ }^{47}$ While in exile in Mexico, in 1924, he established the APRA (with the aid of Mariátegui), and in 1930 he founded the Aprista Party. ${ }^{48}$ In 1927, Haya de la Torre began to distance himself from the USSR and the Communist International (an international organization founded in 1919 in Moscow to unite Communist parties and organize revolutionary struggles). The APRA's break with the International strained Mariátegui's relationship with the APRA. ${ }^{49}$ Haya de la Torre sought to break away from the Communist International and create a Latin American "Kuomintang." ${ }^{50}$ What followed was a series of disagreements between Mariátegui and Haya de la Torre and Mariátegui's eventual break from the APRA. The differences between the two centered fundamentally upon their interpretation of Marxism and indigenismo, a movement that sought to assert indigenous rights. ${ }^{51}$ The

\footnotetext{
${ }^{46}$ Mariátegui, Seven Interpretive Essays on Pertvian Reality, XXIX.

${ }^{47}$ Pablo C., Contreras, "Struggles for Modernization: Peru and the United States, 1961-1968," (PhD dissertation, University of Connecticut, 2010), http://proxy.library.carleton.ca/login?url=http://search. proquest.com.proxy.library.carleton.ca/docview/896626324?accountid=9894.

${ }^{48}$ Christine Hunefeldt, A Brief History of Peru, (New York, NY: Facts on File 2004): 193.

${ }^{49}$ Harry E. Vanden, "Mariátegui: Marxismo, Comunismo, and Other Bibliographic Notes," Latin American Research Review, 14.3 (1979): 62.

${ }^{50}$ Ibid. Kuomintang is the Peoples National Party of China, founded in 1912. Haya de la Torre, beginning in 1927: "began to disassociate himself from what he thought was the bureaucratic determinism of the 'official revolutionaries,"' 62 .

${ }^{51}$ Contreras, "Struggles for Modernization: Peru and the United States, 1961-1968," 35.
} 
ideological differences that divided the Mariátegui and Haya de la Torre came to typify socialist movements in Peru and provide valuable insight into the complexity of Peruvian politics.

While indigenismo was a notion that both men incorporated into their conception of a socialist utopia, how they interpreted it and employed it varied significantly. Indigenismo was a movement not confined to Peru, but was a social, cultural, and political campaign across Latin America. ${ }^{52}$ It was a reaction to modernity - the arrival of democracy, typically in the $1820 \mathrm{~s}$, as countries gained independence, which created new space in which the peasantry could lay claim to rights within the nation..$^{53}$ Jorge Coronado states that, while there was a strong indigenista trend in the colonial and republican periods, its adherents more clearly defined the movement in the first decades in the twentieth century, as there was a heightened sense of urgency to define nations and create nationalist pride after Peru lost the War of the Pacific to Chile in $1883 .{ }^{54}$ The articulation of indigenismo varied between individuals and regions. To distinguish and delineate the vast variations of the movement is well beyond the scope of this thesis. Distinctions between Mariátegui and Haya de la Torre, however, are revealing of the differentiations of indigenismo and, more generally, of how ideologies of socialist actors came to divide them.

Mariátegui, while a mestizo (mixed race person) himself and part of the provincial mestizo middle class, did not envision this class as the model for the nation

\footnotetext{
52 Jorge Coronado, The Andes Imagined: Indignenismo, Society, and Modernity (Pittsburgh, PA: University of Pittsburgh Press, 2009): 1.

${ }^{53}$ Ibid., 2-5.

54 Ibid., 6.
} 
and refutes the possibility of the mestizage as agents of change. ${ }^{55}$ Rather, he likens criollo (locally born people of European descent, typically Spanish) and mestizo people to colonizers who abandoned their indigenous heritage to capitalize on material wealth. ${ }^{56}$ Moreover, he states that: "we protest against the instinctive attempt of the criollo or mestizo to reduce [the land problem] to an exclusively administrative, pedagogical, ethnic, or moral problem in order to avoid at all cost recognizing its economic aspect." ${ }^{, 57}$ Rather, he asserts that the issue is fundamentally a socioeconomic problem. ${ }^{58}$ His view of modernity was inherently Marxist as he envisioned a classless society that would arise out of the confrontation between the unstable capitalist market and the indigenous masses. ${ }^{59}$ This conceptualization of a classless society that was based on a strictly indigenous movement contrasted with Haya de la Torre's assertion of a middle-class revolution.

Haya de la Torre disagreed with the Communist International's insistence upon the struggle of one class against the rest. He sought to create APRA as an "alliance of many classes" and focused upon strong Nationalist sentiments. ${ }^{60}$ Moreover, by 1938, APRA stopped referring to itself as Marxist altogether. ${ }^{61}$ As Pablo C. Contreras points out, Haya de la Torre was not convinced that socialism was possible in Peru, and rather anticipated a cross alliance led by the middle class with

\footnotetext{
${ }^{55}$ Ibid., 30-32.

${ }^{56}$ Mariátegui, Seven Interpretive Essays on Peruvian Reality, 5-6.

${ }^{57}$ Ibid., 31.

${ }^{58}$ Ibid.

${ }^{59}$ Coronado, The Andes Imagined, 45. Mariátegui perceived the necessity of integrating European intellectual thought into the movement. This should not be mistaken as a total acceptance of the theories but rather he: "credited European social theories with allowing him to see the plight of Latin America, at the same time that he insisted those theories must undergo transformations in accordance to local reality," 36.

${ }^{60}$ Ibid.

${ }^{61}$ Amold Payne, The Peruvian Coup D'Etat of 1962: The Overthrow of Manuel Prado, Political Studies Series, no.5 (Washington, D.C.: Institute for the Comparative Study of Political Systems, 1968): 11.
} 
workers and peasants in the rise of an anti-imperialist state. ${ }^{62}$ While an antiimperialist, Haya de la Torre did value capitalist investment in Peru and viewed it as the only path to development. ${ }^{63}$ Mariátegui conversely viewed imperialism and capitalism as inseparable and argued that, as long as there were capitalist interests being pursued in Peru, imperialism would continue. ${ }^{64}$ The ideological differences between them created deep fractures not only with the Communist International but inevitably between Mariátegui and Haya de la Torre as well. What began as collaboration resulted in a decisive split in socialist ideology in Peru. Haya de la Torre went on to maintain a prominent position in Peruvian politics, although he continued to further move to the right.

Haya de la Torre was a prominent political actor until the 1970s. In 1930, Haya de la Torre returned from exile in Mexico to Peru to run for President representing the Aprista Party. A populist party, APRA pledged to undertake numerous reforms that would seize power from the aristocracy and transfer power to the masses, thereby creating a national revolution that would ensure socio-economic justice. ${ }^{65}$ Although the party had gained modest support- from the working and middle classes, women, students, and liberal hacendados (hacienda owners) — the party lost the campaign. ${ }^{66}$ Upon losing, Haya de la Torre was imprisoned by the winning candidate, Luis Miguel Sánchez Cerro, until 1933, when Sánchez Cerro was assassinated ${ }^{67}$ The ascendance of Sánchez Cerro to power marked the renewal of

\footnotetext{
${ }^{62}$ Contreras, "Struggles for Modernization," 35.

${ }^{63}$ Hunefeldt, A Brief History of Peru, 193.

${ }^{64}$ Ibid., 194.

${ }^{65}$ Jaymie P. Heilman, "We Will No Longer Be Servile: 'Aprismo' in 1930s Ayacucho, Journal of Latin American Studies, 38.3 (2006): 491-518. http://www.jstor.org/stable/3875869

${ }^{66}$ Ibid., 491-2.

${ }^{67}$ Ibid., 494. "The young man who shot President Sánchez Cerro was a partisan of APRA."
} 
militarism in Peru, which had begun in 1930 and continued sporadically into the $1980 \mathrm{~s}^{68}$ While these military dictators were far from uniform in their governance, often the Apristas and other socialist oriented parties were politically repressed. ${ }^{69}$ For example, in 1934, Óscar Raymundo Benavides Larrea replaced Sánchez Cerro and outlawed the APRA. ${ }^{70}$

The ability of the APRA to gain legitimacy in Peruvian politics depended significantly on the government in power. The party was able to gain political prominence under Manuel Prado Ugartache, who governed Peru from 1957 until $1962 .{ }^{71}$ In an attempt to secure his presidency, Prado made a pact with Haya de la Torre, which became known as the Pact of Monterrico. ${ }^{72}$ According to the pact, if the APRA supported Prado, he would in turn legalize the APRA. ${ }^{73}$ While the military still closely monitored APRA, the support that Prado received from APRA resulted in a break within the party as far left-leaning Apristas broke off and formed the APRA Rebelde (Rebel APRA) in 1959, which in 1962 became the Movimiento de Izquierda Revolucionaria (Movement of the Revolutionary Left- MIR). The reason for the split was that the splinter group argued that the alliance was la convivencia (a cohabitation) or super-convivencia, (super-cohabitation), implying that the

\footnotetext{
${ }^{68}$ Hunefeldt, $A$ Brief History of Peru. "A third era of military rule (called the 'third militarism' by historian Jorge Basadre) began in 1930 with Sánchez Cerro, continued with Benavides between 1933 and 1939, and reappeared between 1948 and 1956 with Manuel A. Odría as president and in the early 1960s with General Ricardo Pérez Godoy (1961-62) and Nicolás López Lindley (1962-63). With General Juan Velasco Alvarado (1968-75) and General Francisco Morales Bermúdez (1975-80) the military cycles came to an end, but the involvement of the military in national issues did not," 201 . ${ }^{69}$ lbid.

${ }^{70}$ Heilman, "We Will No Longer Be Servile," 494. .

${ }^{71}$ This was Prado's second term. He also served in 1939 until 1945.

${ }^{72}$ Leslie Bethell (ed.), The Cambridge History of Latin America: Latin America since 1930, (Cambridge: The University of Cambridge Press, 1991): 441.

${ }^{73}$ lbid.
} 
Prado/APRA coalition was illegal and immoral. ${ }^{74}$ The ideological differences that had previously divided Mariátegui and Haya de la Torre reappeared in 1959 with the creation of APRA Rebelde. While the Prado/APRA alliance generally represented the aspirations of the middle class, APRA Rebelde maintained a much more radically left platform that focused on the peasantry and indigenous peoples. ${ }^{75}$ Moreover, the Prado/APRA coalition signalled that the largest Leftist party in Peru had assumed a much more Conservative position. This transition created a vacuum out of which several new left parties were formed. ${ }^{76}$

Several parties were formed in response to the APRA/Prado coalition. Acción Popular (Popular Action- AP) was the leading party and was founded by Fernando Belaúnde Terry in $1956 .{ }^{77}$ Politically, while the party attempted to straddle a center position, in the 1962 and 1963 election, the party: "seemed to be moving toward left of center"78 and unofficially maintained alliances with the Communist party and other Social Progressive advisors and technicians. ${ }^{79}$ Given that the AP had been formed so recently, it was generally thought that, without APRA support, Belaúnde had little hope of winning the 1956 Presidential election. ${ }^{80}$ Yet, as discussed above, Prado won the election. But it was a close race-Prado received 45.1 percent of the votes while

\footnotetext{
${ }_{75}^{74}$ Hunefeldt, A Brief History of Peru, 218.

${ }^{75}$ Contreras, "Struggles for Modernization," 69.

${ }^{76}$ Payne, The Peruvian Coup D'Etat, 19.

${ }^{77}$ Belaúnde was a U.S.-trained architect and university professor.

${ }^{78}$ Jean Pierre Bernard, Silas Cerqueira, Pierre Gilhodès, Hélène Graillot, Leslie F. Manigat, Hugo Neira, Guide to the Political Parties of South America, Michael Perl [trans.], (Baltimore, MA: Penguin Books 1973), 431. This is further confirmed by Payne in The Peruvian Coup D'Etat, 27. He asserts that Belaúnde launched a Marxist Social Progressive Movement, which was comprised mainly of his former students. Also see: Barry Steven Levitt, "Continuity and Change in Peru's Political Parties, 1985-2000 (Paper presented at Congress of the Latin American Studies Association (LASA), Miami Florida, 2000), 8-9.

${ }^{79}$ Bernard et al., 439. It was not until the 1980 election that the party began to assume a right of center position.

${ }^{80}$ Payne, The Peruvian Coup D'Etat, 28-9.
} 
Belaúnde came in second with 36.3 percent. $^{81}$ While, in 1956, the AP was still a young party, by 1962, it had assumed the position of the most popular and well organized leftist party. ${ }^{82}$ In addition, it had garnered the support of prominent former APRA members, such as Ciro Alegria, a renowned Peruvian novelist. ${ }^{83}$ The rise in AP support positioned the party to contend in the upcoming election with the real possibility of winning. Furthermore, Belaúnde would later become the president of Peru twice, first in 1963 and again in 1980. The creation and success of the AP demonstrates the ability of the Left to contend consistently in elections, indicating the existence of a popular support base within the general population. The establishment of the AP was a direct result of the APRA moving from the left to a more conservative position. Moreover, while the APRA/Prado coalition created a political vacuum, it resulted in a wider proliferation of leftist parties. In addition, with the legalizing of a leftist party, APRA, more radically leftist parties also gained the ability to compete in national elections, such as the ones held in 1962.

By 1962, Peru had its first competitive elections, in which several presidential candidates ran, including parties from the Left. ${ }^{84}$ This was a significant moment in Peruvian history as, historically, power had resided in the armed forces, which used strong arm tactics to weaken any potential competition. ${ }^{85}$ In addition, the success of the Cuban Revolution in 1959 further galvanized the socialist cause in Peru and brought attention to the highly unequal distribution of wealth. The Cuban Revolution

\footnotetext{
${ }^{81}$ Ibid., 31 . Prado received 568,134 votes and Belaúnde 457,638 votes.

${ }^{82}$ Ibid., 33.

${ }^{83}$ Ibid., 34.

${ }^{84}$ Contreras, "Struggles for Modernization," 73. See also: Payne, The Peruvian Coup D'Etat.

${ }^{85}$ Payne, The Perwvian Coup D'Etat. This was legalized through Article 53 of the Constitution from 1933 which outlawed international parties. Moreover, the oligarch did not require parties as the military served their interests, 7 .
} 
precipitated a distinct change in Peruvian politics and in part led to a rise in the radical front in the 1962 election. ${ }^{86}$

One of the contending political parties in 1962 was represented by Haya de la Torre, who was able to garner the support of the various other parties. This alliance consisted of the Movimiento Democrático Peruano (MDP) and its president at the time, Manuel Cisneros Sánchez, who was supported by Nacional Independiente (National Independent) and its leader Pedro Gerardo Beltrán Espantoso (prime minister and finance minister under Prado).$^{87}$ In gaining this support, the Apristas: "bore the stigma of representing the official candidacy." 88 On the Left, there were several presidential candidates: Luciano Castillo of the Socialist Party; Alberto Ruiz of the Social Progressives (who supported Belaúnde in 1956); and César Pando Egúsquiza of the National Liberation Front (FLN). The two forerunners on the Left were former dictator Manuel Odría, under the party Unión Nacional Odriísta (Odriist National Union- UNO), and Belaúnde, who ran for the APs. While Odría is typically considered more conservative and a representative of the right, he positioned himself as left of right and would later attempt to form a coalition with parties on the left.

\footnotetext{
${ }^{86}$ Contreras, "Struggles for Modernization," 69.

${ }^{87}$ Ibid. Contreras states that: "The severe economic crisis that exacerbated the deep-rooted social unrest and political tension during the first half of his six-year second term had prompted Prado to appoint Pedro G. Beltrán, a strong critic of his administration, as prime minister and finance minister in mid-July 1959. Although his government became the last traditional oligarchic regime, Prado and Beltrán represented a more enlightened wing of Peruvian oligarchy who favoured moderate reforms as essential to maintain the status quo. A British-trained economist who advocated traditional liberal, free-market economic policies, Beltrán first set out to confront the economic crisis implementing a harsh austerity program that included a major reduction in government spending, the elimination of food subsidies, and to attract more foreign investment, the ICP was permitted to raise prices on petroleum products, prompting the price of gas to more than double From the outset, U.S. embassy officials in Lima believed that Beltrán's program represented the best opportunity since President Prado took office in 1956 to bring about economic and social stability to Peru and thus preclude social revolution," 92-93. Beltrán further encouraged U.S. intervention in Cuba specifically and against the Communist threat in Latin America more generally although the relationship soon deteriorated, and as is discussed, led to the U.S. to hope that Haya de la Torre would win the 1962 election, 93-106.

${ }^{88}$ Payne, The Peruvian Coup D'Etat, 37.
} 
This election was important because it demonstrates the fluidity of political parties. In attempts to consolidate their power, factions that were once dedicated to the left moved to the right and vice versa. This indicates that the socialist nexus in Peru was not a fixed or linear movement and was constantly in flux. While individuals such as Haya de la Torre abandoned their position on the left, new actors filled the vacuum and the Leftist current in Peru remained a political force that parties on the right were forced to reckon with.

From the beginning of the 1962 election, Belaúnde, Haya de la Torre, and Odría were the candidates who were favoured. Belaúnde's platform promised land reform and public works. In February 1962, the United States Assistant Secretary of State for Inter-American Affairs, Robert Woodward, lauded Haya de la Torre as: "the strongest anticommunist force in Peru." ${ }^{89}$ In the US, he was regarded as someone who would lead a middle-class revolution rather than a "worker/peasant" revolution. ${ }^{90}$ According to a Central Intelligence Agency study, the APRA: "as an initial 'radical and violent revolutionary organization' had changed its 'character' and its leaders had 'matured." 911 Conversely, both Odría and Belaúnde sought to retain Communist support during their campaign-even if only to break popular support for APRA. Belaúnde maintained a reformist line that focused on bringing social and economic change for the Andean people, in addition to seeking the support of the military. ${ }^{92}$ Odría, even though a candidate of the Right, promoted himself as: "a

\footnotetext{
${ }^{89}$ Ibid., 106-109.

${ }^{90}$ Ibid.

91 Ibid., 108.

${ }^{92}$ Contreras, "Struggles for Modernization," 109-110.
} 
'socialist of the Right,", ${ }^{, 93}$ and sought support from the beneficiaries of his former public works, including women, businessmen, and industrialists. ${ }^{94}$

Elections were held on June $10^{\text {th }}, 1962$. It was not until July $17^{\text {th }}$ that the tabulations were completed and published, at which point the National Election Jury, according to Arnold Payne, declared that Haya de la Torre (Alianza Democrátic) received 32.94 percent of the vote, Belaúnde (AP) 32.19 percent, and Odría (UNO) 28.44 percent. ${ }^{95}$ While Haya de la Torre had won by a small margin, the Peruvian constitution states that, to win the Presidential election, the candidate must receive a minimum of 33.33 percent of the votes, which meant that the decision of who would be President would have to go through a new Congress, which would be responsible for electing the new President. ${ }^{96}$ While there was no decisive victory, the results demonstrate that the Leftist parties had established a strong foothold in the political landscape.

While the Left was able to establish itself in the election, the military decisively moved to exclude the possibility of a Leftist government. Amid rumours of ballot fraud and increasing tension during the period between the casting of the ballots and the final tabulation, Haya de la Torre stepped out of the race on July $4^{\text {th }}$, 1962 to prevent a military overthrow. ${ }^{97}$ The resignation of Haya de la Torre from the presidential race was a consequence of ultimatums that the military presented to

\footnotetext{
${ }^{93}$ Ibid., 110. Also in Payne, The Peruvian Coup D'Etat, 38.

${ }^{94}$ Payne, The Peruvian Coup D'Etat. Women had been granted suffrage under Odría and his wife, María Delgado de Odria, campaigned in the barriadas (slum-like dwellings) in an effort to gain popular support. Several prominent businessmen and industrialists had profited under his regime and he also aimed to garner their vote.

${ }^{95}$ My calculations are based on the total numbers recoded in Payne, The Peruvian Coup D'Etat, 43. See Appendix II Final Election Results Released by the National Election Jury, July $17^{\text {th }} 1962$ for the numerical results.

${ }^{96}$ Contreras, "Struggles for Modernization," 122. Also see Payne, The Peruvian Coup D'Etat, 43-44.

${ }^{97}$ Ibid., 125.
} 
Prado. Contreras asserts that the military presented Prado with two possible courses of action. First, in late June, in an attempt to thwart conflict over the results, Prado attempted to remove the commander of the air force, General Prado Vargas Prada, who had refused to declare a Belaúnde Presidency. ${ }^{98}$ In response 100 military officers, including eleven generals, threatened to resign in protest and the General was reinstated. ${ }^{99}$ Secondly, the armed forces informed Prado that a Haya de la Torre presidency would not be acceptable and that he should withdraw. Prado relayed this message to Haya de la Torre, who subsequently resigned from the presidential race. ${ }^{100}$ On July $16^{\text {th }} 1962$, the military quickly stepped in and demanded that the entire election be cancelled. The National Election Jury ostensibly denied the legality of such a manoeuvre, a truly rare moment in Peruvian politics before the $1960 \mathrm{~s}^{101}$ In an attempt to resist a military coup, Prado fostered talks between Belaúnde and Odría to form a coalition. Talks also occurred between Odría and Haya de la Torre.

Ultimately, all of the attempts at combined action eventually failed and tensions continued to rise. Ten days before the end of Prado's term, tanks surrounded the presidential palace and the military occupied strategic locations in Lima. ${ }^{102}$ On July $18^{\text {th }}$, General Ricardo Pío Pérez Godoy assumed political power in Peru until the next scheduled (and promised) constitutional election of $1963 .{ }^{103}$ Generally speaking, the

\footnotetext{
${ }^{98}$ Ibid., 123.

${ }^{99}$ Ibid.

${ }^{100}$ Ibid., 125.

${ }^{101}$ Payne, The Peruvian Coup D'Etat, 47.

${ }^{102}$ Contreras, "Struggles for Modernization," 132.

${ }^{103}$ Ibid. It should be noted that this military coup was different from the many other coups that had occurred in Peruvian history. Both Contreras and Payne distinguish this from the other coups in that this was the first instance where the military had acted as a cohesive unit and was not based on one caudillo (a strong-man who rises to power through violence and charisma, often maintains patronclient relationship with the populace whereby he provides protection in return for support) assuming power, nor was it an extension of the power of the oligarchy, 125-150.
} 
Peruvian Communists backed the military golpe (coup d'état), which the Americans considered a "major and frightening development."104 While the Left had not been able to secure a presidential term, they continued to launch movements across Peru. However, a military junta again threatened the legality of the Left and ushered in another period of repression.

In the year leading up to the 1963 election, the junta undertook moderate reforms, including the development of the Instituto Nacional de Planificación (National Planning Institute- INP) and the Instituto de Reforma Agraria y Colonización (Institute of Agrarian Reform and Colonization - IRAC). ${ }^{105}$ It also committed to a limited agrarian reform program in La Convención in March 1963, the site of a peasant uprising led by Hugo Blanco in the early part of the 1960s (this will be discussed in greater detail in Chapter Two). While modest, the program was the first endeavour by any Peruvian government to systematically redistribute land. ${ }^{106}$ While the movement had been supressed for a time, the fact that the military implemented reforms in the region indicates that the Left was able to have some influence on the government, as strong arm tactics were not the only ones employed. Rather, in combination with force, the military was forced to recognize the inequitable land holding patterns that existed and implement reformist measures.

While the military golpe advanced a series of reforms, it is important to recognize that it was not sympathetic to the Leftist cause. Under military rule, masses of Communist labour organizers were arrested and repressive measures were enacted,

\footnotetext{
${ }^{104}$ Ibid., 140.

${ }^{105}$ Contreras, "Struggles for Modernization," 157.

${ }^{106}$ Ibid., 160.
} 
including the suspension of constitutional guarantees. ${ }^{107}$ For example, from January $4^{\text {th }}$ to $5^{\text {th }} 1963$, over eight hundred members of leftist groups and known Communists were arrested including the FLN's General César Pando Esgusquiza (presidential candidate in 1962), Luis Alvarado (head of the union for bank employees'), and Guillermo Sheen (chief of the commercial employees' union). ${ }^{108}$ The government justified the arrests by saying that it suspected the Communists had united and were conspiring to conduct a series of hit-and-run raids across the country between January $15^{\text {th }}$ and $20^{\text {th }} \cdot{ }^{109}$ Approximately 200 people were held for an extended period of time; 61 of them went to trial but none of them were convicted due to a lack of evidence. ${ }^{110}$ Moreover, with the majority of Communists in jail, the military swung sharply to the right and began to deemphasize reform. Beginning in January, it was also becoming apparent that the military was no longer united and dissension in the ranks began to occur. ${ }^{111}$

The swing to the right was further evident by early March. Three months before the upcoming election, Pérez Godoy was ousted by General Nicolás Lindley López, who assumed power and reversed some of the previous reforms Godoy had enacted. ${ }^{112}$ Although there were fears nationally and internationally that the military would outlaw the APRA and further cancel the 1963 elections and maintain power, this was not the case. ${ }^{113}$ As had occurred in the 1962 election, Haya de la Torre,

\footnotetext{
${ }^{107}$ Daniel M. Masterson, Militarism and Politics in Latin America: Peru from Sánchez Cerro to Sendero Luminoso (Westport, U.S.: Greenwood Press, 1991), 191.

${ }^{108}$ Ibid.

${ }^{109}$ Ibid., 191-2.

${ }^{110}$ Ibid., 192.

${ }^{111}$ Ibid., 192-4.

${ }^{112}$ Ibid., 195. The reforms mentioned earlier did, however, remain in tact. The most significant reversal was a raise in taxes that would inevitably benefit the wealthy.

${ }^{113}$ Contreras, "Struggles for Modernization," 179.
} 
Belaúnde and Odria were the popular candidates. The military did, however, back Belaúnde and it is probable that there would have been another military intervention to avert a Haya de la Torre presidency. ${ }^{114}$ Further, with many leading leftists still in jail, there were no hard-line Leftist candidates in the election (Partido Socialista, Partido Social Progresista, and FLN lacked any form of representation, in contrast to the 1962 election, in which they had collectively received nearly sixty thousand votes). ${ }^{115}$

With radically left representatives in jail, Belaúnde won the election with 39 percent of the vote. Haya de la Torre received 34.3 percent of the vote, and Odría received 25.5 percent of the vote. Since Belaúnde did not win with a majority, he was forced to form a minority government and as such faced an antagonistic congress. ${ }^{116}$ Although Belaúnde promised sweeping reforms and many developmentalist policies, the Peruvian government did not have enough revenue to enact the promised reforms. ${ }^{117}$ Land invasions, which had been occurring across the country, particularly in the North, continued to escalate and the opposition consistently blocked Belaúnde's efforts to bring about proposed reforms. Another issue that was inhibiting Belaúnde from instituting reform was a decline in US aid and a rapidly deteriorating

\footnotetext{
${ }^{114}$ Masterson, Militarism and Politics in Latin America, 196. Almost all sources that discuss this also allude to the fact that this is also reflected in the fact that that the military enacted new election laws and closely monitored the elections in an attempt to prevent fraudulous activity.

115 Ibid.

${ }^{116}$ Ibid., 197.

${ }^{117}$ Contreras, "Struggles for Modernization," 193.
} 
Peruvian economy. ${ }^{118}$ As Belaúnde was unable to enact the promised reforms, the left continued to gain momentum across Peru.

By 1964, there was growing tension across the country and the MIR was gaining strength. ${ }^{119}$ Belaúnde's inability to bring change to the countryside ignited a guerrilla campaign, launched by the MIR, that sought to eliminate US economic domination of Peru through revolutionary tactics ${ }^{120}$ The MIR also had the support of the Ejército de Liberación Nacional (National Liberation Army-ELN), and the Túpac Amarus - both of which represented an upsurge of Marxist/Communist sentiments. Héctor Béjar was a leading figure in the insurrection. He had been a member of the Communist party since adolescence and continued on as press secretary for the party. Further, in 1965 he founded and edited the party's newspaper, Unidad. ${ }^{121}$ He was ousted from the party in 1959 over ideological differences, but soon thereafter, in 1962, established the ELN. ${ }^{122}$ Béjar's influence and activity in the Left further exemplifies the fluidity and lack of unity within the Peruvian socialist nexus. As actors and parties became divided, new splinter groups were created.

The ability of some actors to unite under the MIR did, by 1965, make a Communist revolution appear plausible. ${ }^{123}$ In response, Belaúnde launched a counterinsurgency with the assistance of the CIA and within seven months crushed

\footnotetext{
${ }^{118}$ Ibid., 221. An economic example is that Peru was the world's leading supplier of fishmeal and this industry provided the country with a majority of its export earnings. In 1963, Peru's external debt was $\$ 235$ million, or 8 percent of GNP, but a significant fishmeal production loss in 1965 led to a striking increase in foreign debt, which, in 1968 , totalled $\$ 680$ million, or 18 percent of GNP.

${ }^{119}$ Ibid., 205. By 1964 the MIR had roughly 900 members and 3,500 sympathizers (according to a CIA report), and were actively training and securing support from Cuba, China, and North Korea.

${ }^{120}$ Ibid.

${ }^{121}$ Héctor Béjar, n.d., personal webpage. Accessed June 10, 2012 from: http://www.hectorbejar.com/

${ }^{122}$ Andrés Alsina, "Hector Bejar's long road," Social Watch, n.d. Accessed June 10, 2012 from: http://old.socialwatch.org/en/acercaDe/prensa7.htm.

${ }^{123}$ Contreras, "Struggles for Modernization," 208.
} 
the MIR movement. The social consequences were devastating; thousands of peasants were dispossessed, approximately 8,000 were left dead, and napalm and bombs demolished vast tracts of land. ${ }^{124}$ Béjar was imprisoned for five years in Lima's San Quintin prison following the uprising. While in prison he wrote The Guerrillas of 1965 in Peru and won the prestigious Casa de las Américas literary award in 1969. ${ }^{125}$ In an interview while in prison, conducted by Winston Orrillo in 1969, Béjar states that the insurrection failed because the new Left was not intellectually, politically, or militarily prepared. ${ }^{126}$ Moreover, he contends that it occurred too late and should have occurred in 1962 under Blanco, because by 1965: "much of the peasant social insurgency had been drowned in blood by the army." ${ }^{127}$ While the movement may have been unprepared and had suffered under the military, the failure of the insurrection is, as Masterson notes, also attributable to the failure of the guerrillas to gain support in urban centers, as had occurred in the Cuban Revolution. ${ }^{128}$

While the revolution had been supressed, Béjar remained optimistic about the possibility of future revolutionary movements. Béjar's confidence in the ability of the revolution to succeed in the future demonstrates the resilience of not only the individual leaders, but of the movements as well. He states:

\footnotetext{
124 Ibid., 211.

${ }^{125}$ The award is given by the Casa de las Américas, an organization that was founded in 1959 and promotes the work of writers, artists, musicians, playwrights, and scholars of literature and arts in Latin America and the Caribbean. For more information on the award see: http://www.casa.cult.cu/. Also see: Héctor Béjar, Peru 1965: Notes on a Guerrilla Experience, trans. William Rose (New York, N.Y.: Monthly Press Review, 1970), 9. "For the Latin American writer, especially a young writer, there are probably no literary prizes coveted as the annual Casa de las Américas awards...Aside from awarding $\$ 1000$ to each author, the books are published by Casa de las Américas and almost immediately translated abroad," 9.

${ }^{126}$ Ibid., 11.

${ }^{127}$ Ibid.

${ }^{128}$ Masterson, Militarism and Politics in Latin America, 217.
} 
In Peru, from 1965 onward, and even before, from the first armed actions of Hugo Blanco, Javier Heraud, and Lieutenant Vallejo, a new stage in revolutionary struggle began. At the moment we are still living through the consequences of the first failures, but the ferment continues[...]This is a stage for search in both action and thought. It is the only way to find the path toward liberation of all people. ${ }^{129}$

Indeed, while the insurrection was removed from the movements of the early 1960 s, there was nevertheless continuity with that past. This continuity is apparent in the fact that while socialist thought and campaigns were effectively suppressed for a while, they still had the capacity of remaining operational and relevant. In addition, as political parties, such as APRA, sought to gain popular support by forging alliances with former enemies, there were several leftist parties that sought to fill the void. The parties that filled this vacuum were often created as splinters from other leftist parties, such as the APRA Rebelde.

Béjar further exemplifies the continuity with past leftist parties. He states that the movement was comparable to the 1931 emergence of the Left, but it increasingly sought to incorporate the peasantry and indigenous peoples. ${ }^{130}$ By 1965 , the evolution in Leftist thought had emerged as the "new Left," which was equally, if not more, divided than the original founding parties. Béjar points to four defining features of the "New Left": first, there was the common idea that the peasantry had to be integrated into the revolution; second, the revolution could only occur through violent means; third, there was a denial of and break from the "traditional" Communist party and the APRA; and fourth, that a political party could only be created out of "action" and not

\footnotetext{
${ }^{129}$ Béjar, Peru 1965, 14-15.

${ }^{130}$ Ibid., 47.
} 
vice versa. ${ }^{131}$ The explicit denunciation of the APRA and the founding Communist party set the "new Left" apart from the original movements, yet many of the emerging leftist parties were created out of the original APRA and CP in combination with other parties from the Left. Ultimately, the new Left was incapable of moving beyond the traditional Left, insomuch that it: "was unable to rise to the great occasions that were awaiting it and it lost $[\ldots]$ several opportunities for uniting the masses." 132 While the revolution launched by Béjar and other leftist leaders may not have been successful in changing the political landscape to align with their ideology, it did, however, place increasing pressure on Belaúnde.

The rise of guerrilla activity coupled with the disintegration of Belaúnde's coalition changed the political landscape of Peru once again. The pressure peaked in 1968 over a petroleum company. The International Petroleum Company (IPC) was first established in 1920 , and had been a source of contention for every government since the signing of the IPC contract. ${ }^{133}$ More importantly, it sparked strong antiimperialist and nationalist sentiments. ${ }^{134}$ During the 1963 campaign, Belaúnde promised to resolve the IPC issue. However, finding consensus on how to solve the matter proved to be an impossible task for Belaúnde and his inability to resolve the issue culminated in a scandal for his administration. ${ }^{135}$ The IPC had a strong hold on the Peruvian economy as it extracted almost 85 percent of all petroleum and supplied

\footnotetext{
${ }^{131}$ Ibid., 48-53. Although he points to these features he does maintain that again there were many variations within the new Left.

132 lbid., 53.

${ }^{133}$ Masterson, Militarism and Politics in Latin America, 98.

${ }^{134}$ Ibid., 224. For example: "IPC's nationalization was continually raised as an issue during the last years of the second Prado administration."

135 Ibid., 205.
} 
all of Peru's aviation fuel. ${ }^{136}$ Belaúnde attempted to negotiate with IPC during his entire presidency. According to the 1922 contract, IPC was granted tax-free status. Belaúnde sought to obtain back taxes from the company and establish sub-soil rights, which angered the US. Between 1963 and 1969, the Americans attempted to control Peruvian governments and did so through the suspension of aid when Peruvian governmental policies did not conform to American expectations. ${ }^{137}$ International pressure applied by the US combined with a failing economy and his inability to settle the IPC issue led to Belaúnde being ousted by a Leftist military junta led by Juan Velasco Alvarado in 1968.

Velasco Alvarado, fondly referred to as El Chino, was very modern for his time and did not conform to either the Communist or Anticommunist blocs. In fact, he ruled by the motto: "ni con el capitalismo ni con el comunismo" (neither capitalism nor communism), although it has been argued that active opposition from the United States led to a stronger relationship with the Soviet Union. ${ }^{138}$ While maintaining a position of nonalignment, he nevertheless established alliances with the Soviet Union, Eastern Bloc countries, and Mao's China, in addition to sustaining amicable relations with Cuba. ${ }^{139}$ Additionally, in 1968 , he initiated a sweeping set of agrarian reforms and redistributed huge amounts of land to the peasants and indigenous peoples in the form of worker cooperatives. The reallocation of land included the expropriation of IPC land with no compensation, which brought the ire of the United States. ${ }^{140}$

\footnotetext{
${ }^{136}$ Ibid., 225.

${ }^{137}$ Ibid., 225.

${ }^{138}$ Enrique Mayer, Ugly Stories of the Peruvian Agrarian Reform, (Durham, NC: Duke University Press, 2009), 2

${ }^{139}$ Ibid.

${ }^{140}$ Masterson, Militarism and Politics, 243-4.
} 
Velasco Alvarado was both revered by the lower classes and despised by the elite. He expropriated foreign business and forbade criticism. ${ }^{141}$ However, while Velasco Alvarado did not tolerate criticism and banned political parties, some Peruvians have remembered him as dictablanda (soft dictator) rather than dictadura (hard dictator). ${ }^{142}$ Through his reforms and attempts at revolution, he did much to create a sense of Peruvian nationalism. For example, Inca and indigenous symbols and names became incorporated into government organizations. ${ }^{143}$ His inclusion of indigenous peoples and the poor into the nation was made explicit on June 29, 1969 in a speech in which he declared:

Today, on the day of the Indian, day of the peasant, the revolutionary government rendered the best of all tributes in giving the entire nation a law that will forever end an unjust social order that has perpetuated the poverty and inequality of those who always worked another's land, and which has always been denied to millions of peasants... From this auspicious $24^{\text {th }}$ of June, the Peruvian peasant will truthfully be a free citizen for whom the nation, at last, recognizes the rights to the fruits of the earth on which he works, and a place of justice within a society in which he will never be, as he was until today, a diminished citizen, a man to be exploited by another man. ${ }^{144}$

Velasco Alvarado's assertion of indigenous and peasant rights did not only extend to public speeches but also to a wider propaganda campaign that promoted the reforms

\footnotetext{
${ }^{141}$ Mayer, Ugly Stories, 5-6.

${ }^{142}$ Ibid., 6.

${ }^{143}$ Ibid. Other examples include: a rise in Peruvian folk performance; Santa Clause was banned and replaced by el niño Manué to make Christmas less American and more Peruvian; and velasquista youth sported ponchos and played the pan-pipes (traditional Andean musical instrument)—even in middleclass neighbourhoods.

${ }^{144}$ Velasco Alvarado Juan, "Mensaje a la Nación con motivo de la promulgación de la Ley de la Reforma Agraria," from Alvarado Velasco, Juan, Voz de la Revolución: Discursos del Presidente de la República, General de División Juan Velasco Alvarado, 1968-1970. Presidential speech issued October 9, 1968, transcribed by Juan Fajardo (2012). Accessed June 18, 2012 from:

http://www.marxists.org/espanol/velasco/1969/junio/24.htm. Original in Spanish, my translation.
} 
which Velasco Alvarado had initiated, which also included a wide range of posters. ${ }^{145}$ These posters were important for articulating the aim of the reforms and in explicitly identifying the intended beneficiaries. While the redistribution of land and the cooperative movements were intended to benefit the peasantry, as Enrique Mayer argues, the cooperatives were still imposed from the top down and were a form of reform that many left-leaning intellectuals applied in Latin America in the post-war era. ${ }^{146}$ Moreover, his speeches to the public were highly idealistic, and the practical issues associated with redistributing the land became increasingly problematic. His inability to ease the land issue stemmed from a lack of technical expertise, conflict over rights to the land and grazing rights, and limited cultivable land. ${ }^{147}$ While the policies and reforms that Velasco Alvarado implemented failed, the Left policies and incorporation of the disenfranchised into the nation demonstrates a significant ability of the Left to establish a foothold in the Peruvian political landscape. This exertion of power further indicates that, while Peru maintained a nonaligned position, it was highly influenced by Left thought.

This reflection of Leftist thought, however, did not always align with indigenous perceptions of nation. Linda J. Seligmann points out that often the elite and/or governmental aims to nationalize and create a sense of continuity with the indigenous past, in this case Incan, are often highly mythologized. ${ }^{148}$ She argues that national integration is defined for the purpose of exclusion as opposed to inclusion.

\footnotetext{
${ }^{145}$ For reproduced copies of the posters see: Anna Cant, "“The Land For Those Who Work It': A visual Analysis of Agrarian Reform Posters in Velasco's Peru," Journal of Latin American Studies, 44.1 (2012).

${ }^{146}$ Mayer, Ugly Stories, xxiii.

${ }^{147}$ Anna Cant, "'The Land For Those Who Work It': A visual Analysis of Agrarian Reform Posters in Velasco's Peru," Journal of Latin American Studies 44.1 (2012): 8.

${ }^{148}$ Linda J. Seligmann, Between Reform \& Revolution: Political Struggles in the Peruvian Andes, Stanford, California: Stanford University Press, (1995).
} 
For example, in her review of hundreds of statements made by state officials, there was never any mention of the possibility of multiple cultures, ethnicities, or religions; there was only one singular possibility for the national framework. ${ }^{149}$ Yet, the rhetoric that the state employed created a situation in which indigenous groups, it was hoped - "out of both moral conviction and strategic manipulation"-would invoke the appropriate national symbols. However, the nationalist rhetoric that Velasco Alvarado expressed was not how the indigenous peoples viewed or understood their incorporation to the nation. The dissonance between official and Andean perceptions created confusion at the official level as the arguments that peasants used to explain their rights to land defied and baffled reform and legal attorneys. ${ }^{150}$

While Velasco Alvarado sought to integrate the impoverished into a national plan, early critics of his reforms argued that they were applied top-down. In response, Velasco Alvarado created el Sistema Nacional de Apoyo a la Mobilización Social (the National System for the Support of Social Mobilization—SINAMOS), through which all government development was implemented. In addition to the various reforms, in 1970, Velasco Alvarado freed political prisoners who had been persecuted under previous governments, including Béjar, who was commissioned to assist with the establishment of SINAMOS and served as its director beginning in 1971, until its abolition in 1975 by Francisco Morales Bermúdez. Inevitably, the organization was unable to complete what it aimed to do. As Anna Cant notes, while the intention was to create a more balanced and integrative framework for development, the framework

\footnotetext{
${ }^{149}$ Ibid., 90.

${ }^{150}$ Ibid., 92.
} 
was too narrow to incorporate multiple perspectives and ended up creating an inordinate amount of bureaucracy. ${ }^{151}$

The anger and frustration that SINAMOS caused is best exemplified by the fact that its offices were purposely burnt down in Cuzco in 1973 and Lima in $1975 .{ }^{152}$ Oxfam Canada was similarly frustrated by SINAMOS. As demonstrated through a 1972 project description for Community development in Lima, there remained a reluctance within SINAMOS to: "let anything out of their direct control or indeed even to trust anyone outside the armed forces," which in turn slowed progress. ${ }^{153}$ Moreover, Oxfam noted that, while there appeared to be a genuine attempt to create a inclusive national framework, SINAMOS was generally ineffective as there was a: "military insensitivity to people's feelings and wishes. Arbitrary decisions [were] taken, bureaucratic procedures devised, criticism [was] resented." 154 In the end, the program never completely came to fruition, as there was strong opposition to it from within the Velasco Alvarado regime, the citizens, and political antagonists. By 1973, not only was there dissention among the citizens and within the military, but Velasco Alvarado's health was deteriorating rapidly which significantly affected his ability to carry out presidential duties. ${ }^{155}$

\footnotetext{
${ }^{151}$ Cant, "The Land For Those Who Work It," 32-3. Masterson, in Militarism and Politics in Latin America notes that during the Lima riot SINAMOS staff were targeted, 86 people died and 155 were wounded. He also states that these riots were organized by the APRA and that Haya de la Torre afterwards admitted to the APRA's involvement, 262.

${ }^{152}$ Ibid.

${ }^{153}$ Project description for community development, Lima, September 1972, box 8, file 10, Latin America: Sub-Committee - Minutes, Development Schedules, Financial Statements, 1972, Oxfam Canada, Library and Archives Canada, Ottawa, ON.

${ }^{154} \mathrm{Ibid}$,

${ }^{155}$ Masterson, Militarism and Politics in Latin America, 260. Velasco Alvarado suffered from an abdominal aneurism and early thereafter had a leg amputated.
} 
Velasco Alvarado's declining health was the impetus for Morales Bermúdez to devise and carry out a coup d'état. The Peruvian economy was declining; there was factionalism in the armed forces; and increasing opposition to Velasco Alvarado's government. By August 29, 1975, Morales Bermúdez removed Velasco Alvarado from power. When he came to power, he declared that he would continue the reforms that Velasco Alvarado had initiated, but before the end of 1975 most of the programs were decommissioned and he opted for more conservative economic policies. ${ }^{156} \mathrm{By}$ the end of 1975 , military personnel who were in favour of the reformist agenda left the government, asserting that the government of Morales Bermúdez was a "counterrevolution." 157 With the removal of Velasco Alvarado, there was much less influence by the left in Peruvian politics. Morales Bermúdez held a general election in 1980 , which Belaúnde again won. ${ }^{158}$

It is not surprising that at the beginning of the 1960 s Peru had a strong and resilient Leftist movement both intellectually and politically. What is exceptional, though, is that beyond monetary aid, Peru was never the object of overt political domination by the United States or any other Anticommunist bloc country. While in the 1960 s the United States deployed organizations that aimed to suppress Communist tendencies through the development of infrastructure, such as road building, health, and education programmes, ${ }^{159}$ there was never an overt plan of intervention such as occurred in Guatemala in 1954, Cuba in the 1960s, or the Dominican Republic in 1965. Rather, in Peru, it was through implicit means that

\footnotetext{
${ }^{156}$ Ibid., 263.

${ }^{157}$ Ibid.

${ }^{158}$ Morales Bermúdez held a general election in 1980, which Belaúnde again won.

${ }^{159}$ This is well documented by Contreras in "Struggles for Modemization."
} 
governments throughout the Cold War hoped to contain and conquer the Communist threat.

From the advent of socialism in Peru in the early 1920s to the rise of the "New Left" in the 1960s, there were commonalities that were prevalent throughout these years, as there was a continual difference between people who identified as being communist or socialist. The inability to create a cohesive movement significantly hampered their capacity to create change. Moreover, the influence of the Left depended considerably upon who was in power. For example, while Velasco Alvarado was sympathetic to the Leftist cause and attempted to create sweeping reforms that were aligned with leftist thought, governments such as Belaúnde's strove to suppress any sign of socialistic activities. The attempt to create a socialist utopia in Peru further demonstrates the heterogeneous nature of the movement and points to multiple actors and political ideologies. From the advent of the indigenismo movement in Peru in the twentieth century, it is clear that there was little consensus on who should lead and how they should launch the revolution. This exemplifies the nexus of political and social relations within the left factions in Peru, which, while connected, were distinct and multifarious. 


\section{Hugo Blanco and the events of 1961 in La Convención Valley, Peru}

As demonstrated in the previous Chapter on socialist movements in Peru from the 1960s until 1975, there was a strong and resilient leftist current that, while not united, placed pressure on successive governments. Although never credited as much as Mariátegui, Haya de la Torre or Béjar, Hugo Blanco launched a socialist movement in La Convención Valley in 1961. He continues to publish articles and speak about the socialist cause in Peru. Blanco's Leftist approach differs from both that of Mariátegui and Haya de la Torre. A self-proclaimed Trotskyist, Blanco, in his book Land or Death, refers to both Mariátegui and Haya de la Torre. While he is directly opposed to the APRA movement and Haya de la Torre, the influence and alignment with Mariátegui is explicit in Land or Death, albeit with certain caveats. Blanco agrees with Mariátegui insomuch as: "The Indian problem is the problem of land...But our oppression is not simply economic. As a sequel to economic oppression, they abuse the Indians of all our countries in many ways." ${ }^{p 160}$ It is clear from this quote that Blanco identifies his cause with a universal struggle and in this way he moves beyond the approach taken by Mariátegui as he identifies the problem of "the Indian" as not simply a Peruvian one. In addition, as will discussed below, the abuses that Blanco cites further demonstrate the inequality of land holding patterns.

In the 1960s mounting dissatisfaction over the disparity between wealthy hacienda owners and an increasingly indebted peasantry led to a revolutionary movement initiated by Hugo Blanco against the hacendados. ${ }^{161}$ Blanco and his peasant followers were largely successful and, in opposition to the government, set up

\footnotetext{
${ }^{160}$ Hugo Blanco. Land or Death: The Peasant Struggle in Peru, trans. Naomi Allen. (New York: Pathfinder Press, 1972):133.

${ }^{161}$ Ibid.
} 
grass-roots institutions to provide for their own system of governance, popular justice, defence and education, which in turn created what Blanco referred to as a pattern of dual power. ${ }^{162}$ This small-scale upheaval ignited various other successive socialist movements and inspired the rise of several revolutionary agitators. ${ }^{163}$ In 1962, in reaction to Blanco's movement, the Peruvian government, led at the time by a military junta headed by Ricardo Pérez Godoy, passed the first agrarian reform law of the country's history. It stated that some land could be maintained by the gamonales (hacienda owners). ${ }^{164}$

The relative success of Blanco's movement did not signify the abrupt end of the hacienda throughout much of Peru, but in the region where Blanco's movement was successful, the peasantry "didn't recognize even one square centimeter as belonging to the hacendado." ${ }^{165}$ The movement did, however, spread insomuch that other Peruvian peasants began to take notice of the upheavals and, upon realizing what was possible, there were land seizures throughout the country. ${ }^{166}$ The movement started by Hugo Blanco appears to be the first attempt to change the nature of land holding patterns in Peru from one dominated by haciendas into a cooperative system. Eric Hobsbawm, in 1969, deemed this uprising to be:

\footnotetext{
${ }^{162}$ Michael F. Brown \& Eduardo Fernández. War of Shadows: The Struggle for Utopia in The Peruvian Amazon. (LA: University of California Press, 1991): 86.

${ }^{163}$ Other movements include the Sendero Luminoso and the American Popular Revolutionary Alliance (ARPA). Specifically, Hector Bejar refers to Blacno's movement in La Convención.

${ }^{164}$ Hugo Blanco, interview by Bill Wienberg. "Peru: Veteran Guerrilla Fighter Hugo Blanco Speaks on Amazon Struggle," World War 4 Report (July 9, 2009). Accessed December 7, 2010 from: http://www.ww4report.com/node/7756 ${ }^{165}$ Ibid.

${ }^{166}$ Ibid.
} 
Map 1: Cuzco Region in Peru

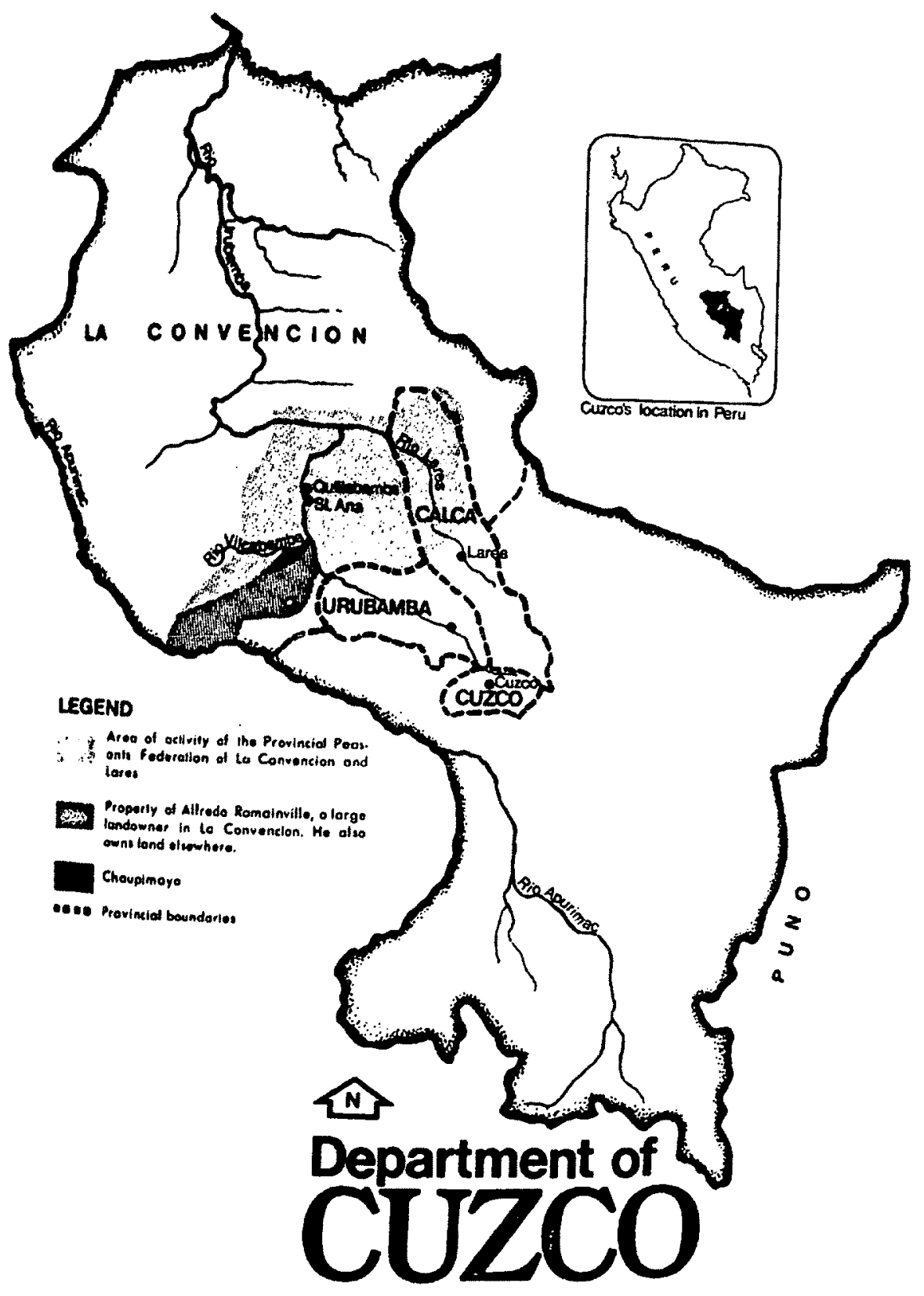

Source: Hugo Blanco. Land or Death: The Peasant Struggle in Peru, trans. Naomi Allen. (New York: Pathfinder Press, 1972): 23. 
Map Z: Geographic regioms im Perw

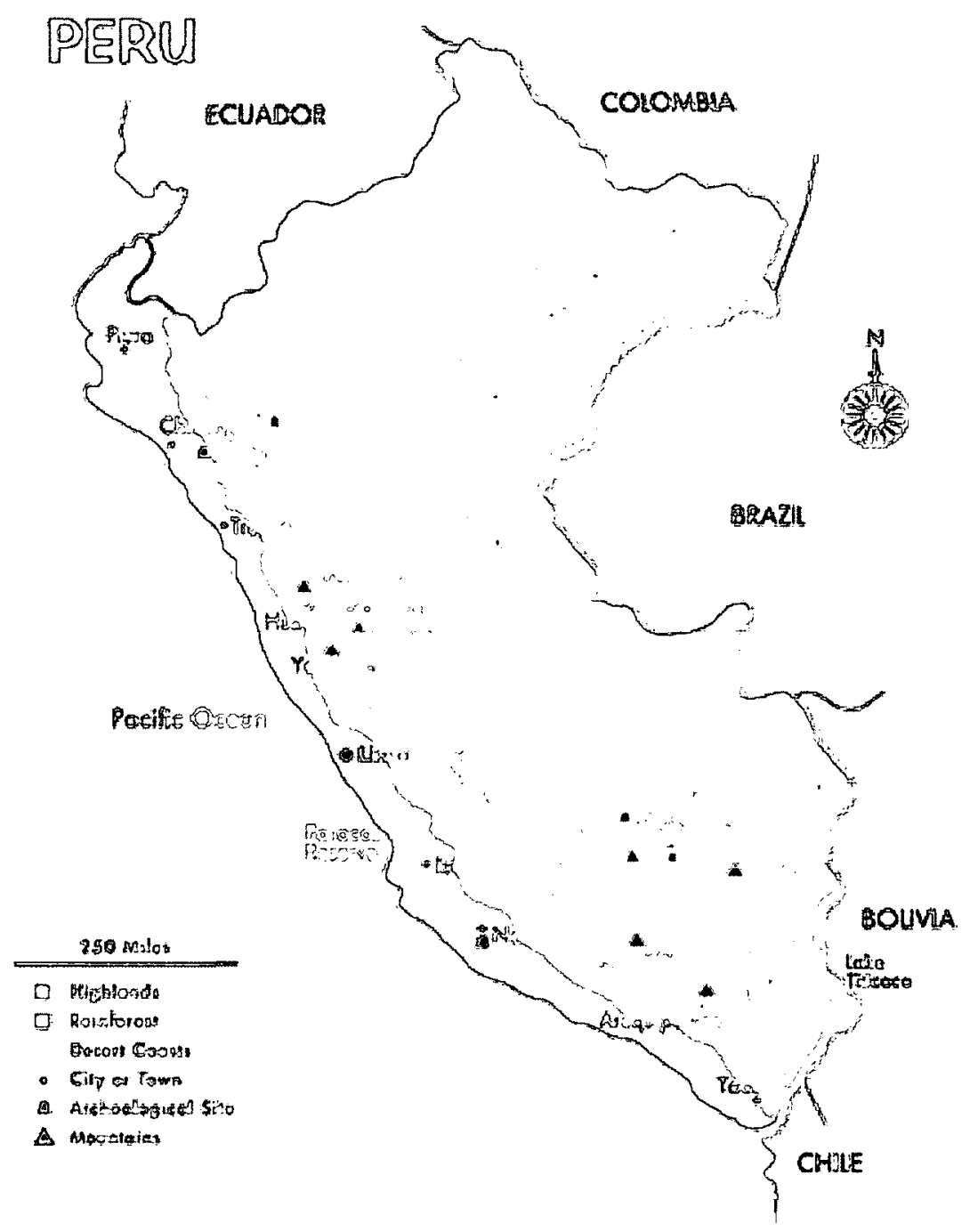

Peru is divided into 3 geographical zones: La costa (the coast), la sierra (the mountains), and la selva (lowlands, typically in the Amazon).

Source: Spanish Central, "Peru: Country Page", n.d., accessed May $18^{\text {th }} 2012$ from: http://spanishcentral.com/Main/Countries/Peru/Peru.html 
"the most important," not only in Peru, but: "probably in the whole of South America." 167 It is therefore important to consider this movement and the way it influenced successive cooperative movements that were launched from the 1960 s to 1975. In addition, it is necessary to examine the geographical and social context in La Convención Valley, Peru, where Hugo Blanco operated in the early part of the 1960s, in order to gain a better understanding of the rationale out of which the cooperative movement was established (see Map 1: Cuzco region in Peru). Geographically, La Convención is part of the Cuzco department, and is part of both the sierra (the mountains) and the selva, (lowlands, typically in the Amazon), and is mostly covered in sub-tropical forests. ${ }^{168}$ The various terrains make the agricultural products from the valley quite diverse (see Map 2: geographic regions in Peru). This region is isolated from the rest of Peru by high and steep mountains that peak at approximately 2,000 and 6,000 meters above sea level, which inhibited access into the valley. This isolation is further exacerbated by the fact that, by 1959 , access into the valley from the main centers was only really possible by a mule path. ${ }^{169}$

By the 1960 s, it is estimated that some 11,000 hectares of land were under cultivation. ${ }^{170}$ The puna (grass-covered windswept plains) is located below the peaks of the mountains and is characterized by a cold climate that receives little rain. ${ }^{171}$ The staple crop of the region is potatoes, but a variety of other root vegetables such as oca

\footnotetext{
${ }^{167}$ E. J. E. Hobsbawn, "A Case of Neo-Feudalism: La Convención, Peru," Journal of Latin American Studies, 1.1 (1969): 31. doi http://dx.doi.org/10.1017/S0022216X00000043.

${ }^{168}$ Blanco, Land or Death, 33. According to Blanco some are as high as 6,000 meters and are perpetually covered in snow (Land or Death, 25).

${ }_{169}$ Ibid., 33. The mule path was constructed in 1890 by the Peruvian government under pressure from the hacendados.

${ }^{170}$ Ibid.

${ }^{171}$ Ibid., 25.
} 
and olluco are grown in addition to quinoa (a cereal from pigweed) ${ }^{172}$ The Andean people in the region also raise chickens, and depend upon pack animals such as alpacas. Descending from the puna, the temperatures become more moderate and rainfall more plentiful. In these lower regions, maize, coffee, cocoa, tea, cacao and some other fruits (bananas, mangos, oranges, and papaya) are grown. ${ }^{173}$ The residents below the puna use pack animals to a lesser extent than those residing in the puna; and pigs, guinea pigs, ducks, and chickens are more common. While initially the main crop that haciendas produced in La Convención was sugar cane, by the 1920s, it was in decline and, by the 1940s and1950s, gamonales switched in large numbers to coffee, tea, and cocoa production. ${ }^{174}$ In 1960 , there were approximately 100 haciendas in total -46 had been established over a century earlier, while 87 were founded throughout the 1950s, indicating that lucrative opportunities were on the rise as the economy of La Convención diversified and entered the global market. ${ }^{175}$

A mode of production in the sierra haciendas or what are also referred to as latifundias (large landed estates), were established during the colonial period and relied upon servile labour. Gamonales tied peasants to the land in a semi-feudal relationship by obtaining the title to an extensive tract of land and "granting" peasants a plot of it in return for their labour. Rent, or canon, was paid in money, labour and other services such as road construction and the transportation of produce. ${ }^{176}$ Other obligations included the use of the peasant's animals. For example, if the tenants owned livestock they were required to forfeit some of the fattened animals to the

\footnotetext{
${ }^{172}$ Ibid., 25.

${ }^{173}$ Ibid., 26.

${ }^{174}$ Hobsbawm, "A Case of Neo-Feudalism," 36.

${ }^{175}$ Ibid., 37.

${ }^{176}$ Blanco, Land or Death, 29.
} 
gamonal and if they owned pack animals, the landlord could use them without payment as well. ${ }^{177}$ This early establishment of unequal relations persisted into the 1960s and contributed to the rationale for the movement led by Blanco.

The disparate relations that came to typify the region were further exacerbated by a shortage of labour. This was especially true in the 1930 s when a malaria epidemic devastated the local population. Hobsbawm notes that the epidemic: "reduced large areas of the province to a human desert." ${ }^{178}$ Fundamentally, the region, Hobsbawm continues, was characterized by having: "abundant land, poor communications and an acute shortage of labour. ${ }^{, 179}$ Increasing labour demands were placed upon the arrendires (labour tenants) by gamonales as they sought to increase their potential for economic growth. In response, the tenants were forced to sublet part of their plot to allegados (sub-tenants), who assumed at least a third of the arrendires' duties. ${ }^{180}$ This system became even more complex when allegados further subcontracted their plot to sub-allegados. ${ }^{181}$ This system of land-holding patterns was highly exploitive and created serious divisions between the wealthy and poor, which contributed to the rise of social actors such as Blanco.

A 1966 study published by the Comité Interamericano de Desarrollo Agricola (ICAD) - (The Interamerican Committee for Agricultural Development) is provided

\footnotetext{
${ }^{177}$ Ibid.

${ }^{178}$ Ibid., 34.

${ }^{179}$ Ibid., 34.

${ }^{180}$ Ibid. "subtenancies are still technically prohibited in most contracts, though the system of allegados is accepted in practice, if only because they increased the number of 'his' workers which the tenant was obliged to put at the disposal of the landlord on the required occasions. Conversely, the official labour services of the arrendires and their dependants became increasingly inadequate for the growing estate economy, and consequently arrangements intermediate between labour services and wage-labour seem to have developed. Such is the maquipura or extra, the obligation to work a certain number of days (up to 20) with all the tenant's dependants, but not for a customary or fixed wage, but for a wage agreed before each duty-period," 41.

${ }^{181}$ Che Guevara, "Case Studies: Peru" in Guerrilla Warfare, $3^{\text {rd }}$ ed. revised by Brian Loveman, and Thomas Jr. Davies, trans. J.P. Morray, (Lincoln, Nebraska: University of Nebraska Press): 281.
} 
in Table 1: The Highlands. It depicts the various types of tenure, the number of units, and the amount of land, on average, that each unit possessed. Table 1 illustrates the inequitable land holding patterns that were evident in Peru by 1961, and gives a general picture of the prevalence of haciendas. ${ }^{182}$ By the 1960 s, large multifamily estates, which included haciendas, accounted for one percent of all production units, yet managed 75 percent of the total available land. The nearly landless families, of which there were 590,000 , had access to only 4.7 percent of the land. Indigenous communities that were officially recognized only accounted for 0.1 percent of the legal units; however, each community was counted only once and not each of the individual members or families. ${ }^{183} \mathrm{Had}$ the total populations of the communities been included, this would have significantly raised the number of family holdings. In total, ICAD records that ayllus had access to 10.5 percent of the land in the highlands. The findings of ICAD indicate that statistically there was an imbalance in land holding patterns in La Convención.

A subsequent land holding study was conducted by José María Caballero in 1972. He argues that hacienda owners had generally exaggerated the extent of their holdings. This assertion brings into question the validity of ICAD's findings. For example, as Mayer points out, ICAD's definition of a hectare was flawed, as the complex ecology of the highlands led to different measurements depending on

\footnotetext{
${ }^{182}$ This study was conducted by the Comité Interamericano de Desrrollo Agricola (CIDA- The Interamerican Committee for Agricultural Development) in the early 1960s and a 500 page report was published in 1966. The study had been widely accepted as accurate until 1972 . The results of this study provided here have been reproduced from Enrique Mayer's Ugly Stories of the Peruvian Agrarian Reform, 2009, Duke University Press, 14. Mayer also includes a second table that pertains to the coast. These two tables demonstrate that a few haciendas across Peru had control over the majority of all available land.

${ }^{183}$ Ibid., 15.
} 
climatic conditions. ${ }^{184}$ Caballero found that the majority of the units were small and unevenly distributed and that massive haciendas were not as numerous as ICAD's findings indicated. While the notion that there was a shortage of land combined

Table 1: Highlands

Peru: Estimated Values by Number and Surface of Agricultural Units by Economic Category for the Highlands, 1961

Agricultural Units

TENURE SYSTEM NUMBER OF UNITS SURFACE

\begin{tabular}{lccccc}
\hline & & & $\begin{array}{c}\text { Total in } \\
1,000 \mathrm{Ha} .\end{array}$ & $\begin{array}{r}\text { Percentage } \\
\text { Total Units }\end{array}$ & $\begin{array}{c}\text { Per Type of } \\
\text { Unit }\end{array}$ \\
\hline $\begin{array}{l}\text { Large Multifamily } \\
\text { Medium }\end{array}$ & 8,912 & 1.3 & 11,450 & 75 & $1,284.80$ \\
$\begin{array}{l}\text { Multifamily } \\
\text { Family Units }\end{array}$ & 19,100 & 2.7 & 760 & 5.0 & 39.8 \\
$\begin{array}{l}\text { Subfamily or Nearly } \\
\text { Landless }\end{array}$ & 88,500 & 12.5 & 724 & 4.8 & 8.2 \\
Communities & 590,730 & 83.4 & 722 & 4.7 & 1.2 \\
\hline Totals & 808 & 0.1 & 1,604 & 10.5 & 1985.1 \\
\hline
\end{tabular}

Definitions

\begin{tabular}{lccc} 
& $\begin{array}{c}\text { Irrigated } \\
(\mathrm{Ha})\end{array}$ & $\begin{array}{c}\text { Rain-Fed } \\
\text { Land }(\mathrm{Ha})\end{array}$ & $\begin{array}{c}\text { Pasturage } \\
(\mathrm{Ha})\end{array}$ \\
\hline Large Multifamily & $>100$ & $>100$ & $>2,500$ \\
Medium & $10-100$ & $50-100$ & $500-2,500$ \\
Multifamily & $3-10$ & $10-50$ & $100-500$ \\
Family Units & $<3$ & $<10$ & $<100$ \\
Subfamily & &
\end{tabular}

Note: $\mathrm{Ha}=$ Hectare

Source: Prepared by the Inter-American Committee for International Development based on data of the First National Agricultural Census and documents of CRAV, CIDA, and CIDA/IRAC case studies and some regional reports. Tenencia de al tierra y desarrllo socio-económico del sector agricola - Perú, p. 107. Translated and reproduced from Enrique Mayer, Ugly Stories of the Perwvian Agrarian Reform, (Durham, NC: Duke University Press, 2009): 14.

\footnotetext{
${ }^{184}$ Mayer, Ugly Stories, "one hectare of irrigated land in favourable climatic conditions below 3,000 meters above sea level is equivalent to 51.6 hectares of puna grasslands above 4,000 meters": 15 .
} 
with ever-expanding haciendas guided reform policies until well into the $1970 \mathrm{~s}$, Mayer argues that such conceptions about land tenure were a myth. ${ }^{185}$

Caballero's study is given much weight in Mayer's text, and he agrees that the miscalculations from ICAD are the reason why reforms that aimed at land distribution ultimately failed. It is important to note, however, that despite errors in ICAD's study, there nevertheless was a growing sense of inequality that the peasants felt, because of the imbalance in land holding patterns. Furthermore, this disparity was not simply located in land distribution but also extended to legal and political power. The majority of the population (the peasantry) was marginalized from the legal and political system and therefore had little recourse to challenge the inequitable land holding patterns. ${ }^{186}$ By the late 1950 s, not only was there an increasing demand for land by people looking to capitalize on the economic boom, but also an increase in the local ayllu population, which was rapidly growing. In 1940, Peru's total population was just under seven million, but by 1961 it had grown to nearly ten million. ${ }^{187}$ As the population expanded, there were increasing demands being placed on access to cultivatable land.

Inequality, and a growing population, contributed to an increasingly antagonistic situation. Tensions heightened as peasants contested the extent of hacienda control over the land, particularly as hacendados owned extensive tracts of

\footnotetext{
${ }^{185}$ Ibid., 16. While there were some titled haciendas, the actual amount of land that they controlled was far less than had been depicted.

${ }^{186}$ Seligmann, Between Reform \& Revolution: "Despite their numbers, Quechua-speaking peasants had been marginalized socially, politically, and economically. Their buying and selling power had been debilitated by unequal terms of exchange on the market. They had been subjected to an extraordinary degree of exploitation by a handful of dominate landowners," 2 .

${ }^{187}$ Contreras, "Struggles for Modernization," 66. This migration resulted in a massive influx of rural people to the urban centers. These migrants came to occupy the barriadas (shantytowns) on the outskirts of the cities.
} 
land, most of which was never cultivated. A 1962 New York Times article demonstrates this point by discussing a dispute on a hacienda in La Convención. The author opens by pointing out the magnitude of the situation in the valley, arguing that it was "potentially a big story." $188 \mathrm{He}$ or she discusses a protest launched by 8,000 indigenous peasants, arguing that while the precise motivation behind the disagreement was unimportant, there was a pervasive discontent across the Southern part of the Peruvian Highlands. ${ }^{189}$ The events at the hacienda began with an administrator who brought a civil suit against some of the tenants for violence and theft, which sparked a revolt. Aside from the civil suit, the peasants protested that a majority of the land that the hacendado owned was not being used. In fact, the article states, only 1,750 acres of the estate's 350,000 acres were under cultivation. ${ }^{190}$ This article from the New York Times confirms that large haciendas often owned more land than they cultivated, which escalated the already tense relations with the peasantry.

Blanco similarly lists abuses against the peasantry in his book Land or Death. He names several gamonales who committed atrocities against the peasants whom they "possessed. " He writes: "The landlord Márquez took the children borne by the women he had raped and drowned them in the river. With a hot cattle-branding iron, the landlord Bartolomé Paz seared into the buttocks of a peasant the emblem of his hacienda." ${ }^{\prime 191}$ While there is certainly room for exaggeration in these narratives, which are often guided by political biases, they are nevertheless significant and relevant to this analysis. These narratives serve to indicate that, while massive

\footnotetext{
188 "The Peruvian Peasant," New York Times, (Nov. 15, 1962): 36. Accessed June 25, 2012 from: ProQuest Historical Newspapers: The New York Times (1851-2008).

${ }^{189}$ Ibid.

${ }^{190}$ Ibid.

${ }^{191}$ Ibid., 94.
} 
haciendas that required numerous workers might not have been as statistically significant as ICAD indicated, such arbitrary use of power was enough to create a situation that was politically and socially unstable.

A burgeoning population combined with the shortage of land and hacienda abuses created a volatile situation that the government simply could not ignore. ${ }^{192}$ President Manuel Prado enlisted Pedro Beltrán, his finance minister, to conduct a study on possible agrarian reforms. Under Beltrán stringent austerity measures were enacted that highly restricted government spending. ${ }^{193}$ While Manuel Prado and Beltrán were able to achieve some economic stability, it came at the expense of the impoverished. ${ }^{194}$ In an attempt to balance the cuts, Beltrán intended to launch a colonizing mission into the selva, to the East of the Andes. In 1961, another New York Times article hailed this initiative to colonize to the East as the solution to the political unrest. The author argues that the issues the indigenous population faced were crop failures, drought, and a land shortage, as well as workers affected by the rising living costs. ${ }^{195}$ However, the previous New York Times article, published a year after 1961, asserts that the issues in the region stemmed from inequitable land holding patterns indicating that Beltrán's colonizing mission was not successful in relieving the tension.

\footnotetext{
${ }^{192}$ Seligmann, Between Reform \& Revolution, 16.

${ }^{193}$ Contreras, "Struggles for Modernization,, 93. These cuts included: the elimination of food stuffs, attempts to attract foreign investment (including allowing the IPC to raise prices, which doubled the price of gasoline).

${ }^{194}$ Ibid., 94-5.

${ }^{195}$ Donald I. Griffis, "PERU'S AUSTERITY PAYING DIVIDEND: Improved Financial Position Is Credited to Premier," Special to The New York Times (Jan 11, 1961): 49. Accessed June 25, 2012 from: ProQuest Historical Newspapers: The New York Times (1851-2008).
} 
It was in this context that Hugo Blanco started his movement in the La Convención valley. He entered the struggle by acquiring a position as an allegado after which he worked to unify several unions in the valley. These unions included the Federación de Trabajadores del Cuzco (Cuzco Federation of Workers- FTC), established in 1950s by sharecroppers with the aid of the CP, and the Federación Provincial de Campesinos de la Convención y Lares (Provincial Peasant Federation of La Convención and Lares- FPCC), which was established by a group of peasants in 1958 and was comprised of several hacienda unions. ${ }^{196}$ The FTC provided the movement with lawyers and labour organizers, and, as will be discussed, was an organization with which Blanco was in constant disagreement ${ }^{197}$ Blanco's initial participation with the unions was rather precarious. He states that the bureaucrats of the unions rejected his nomination as the union delegate to the FTC, and systematically sought to exclude Blanco from participating in the federation or organizing the FPCC in La Convención. ${ }^{198}$ It was not until after having been jailed for organizing a strike in Lima in 1960 that Blanco was able to become directly active with the unions. The FTC was pressured by the peasantry to push for his release by threatening a work stoppage. The tactic worked, thereby making it nearly impossible for the bureaucrats to prevent Blanco's direct participation in the FPCC and FTC from then on. ${ }^{199}$ Ultimately, Blanco was instrumental in uniting the local unions and leading the "tierra o muerta" (land or death) uprising.

\footnotetext{
${ }^{196}$ Contreras, "Struggles for Modernization," 166.

${ }^{197}$ Guevara, "Case Studies: Peru," 281.

${ }^{198}$ Blanco, Land or Death, 21.

${ }^{199}$ Ibid.
} 
The initial exclusion of Blanco from the unions is indicative of the extent to which the Left was fractured in Peru. He cites his exclusion as symptomatic of the FTC's delegates because they were not a union of peasants, but rather a group of "artisans" who "represented" the masses. ${ }^{200}$ Despite the lack of peasant leadership, Blanco maintained that it was fundamental to unite the unions across the Andes to produce a massive movement that would consistently bring about the desired changes. ${ }^{201}$ Essentially, the unions were a means to an end. In order to locate and differentiate between the various forms of self-proclaimed communists and/or socialists in La Convención and to understand the unions' hesitation in allowing Blanco to participate, it is important to understand Blanco's position and opposition to the groups and people that he refers to as "opportunists."

Blanco's antagonism to the APRA is clear from the outset of Land or Death. To understand his opposition to the Aprista movement, I will provide a brief outline of the rise of the Trotskyist party in Peru. The Partido Obrero Revolucionario (Revolutionary Workers Party- POR) was established in 1946. It was the first Trotskyist party in Peru and belonged to the Peruvian section of the Fourth International. ${ }^{202}$ As discussed in the previous chapter, under General Manuel Odría, there was a general suppression of Leftist parties, and the same applied to the POR. Many of its members were exiled or jailed. ${ }^{203}$ Blanco identifies this particular time of repression as the moment when ideological divisions within the party began to become clear. He states that: "The great crisis in the world Trotskyist movement

\footnotetext{
${ }^{200}$ Ibid.

${ }^{201}$ Contreras, "Struggles for Modernization," 166.

${ }^{202}$ Blanco, Land or Death, 19.

${ }^{203}$ Ibid.
} 
during that period had an impact on the exiles, and when they returned to Peru after eight oppressive years, two PORs emerged."204 One faction of the POR sought to establish a "true" leftist workers' revolutionary party that would follow a revolutionary path, given that the APRA and the CP were deemed as corrupt and beyond reform. ${ }^{205}$ Eventually, however, Blanco claims that the leader, Ismael Frías, began to retreat from this concept and lose confidence in the ability as well as the potential of the Peruvian revolution to directly form its own party, and therefore sought to join forces with the APRA. ${ }^{206}$ The other faction, the one with which Blanco preserved ties, sought to maintain independence from other parties and create a system of workers' unions. It did not form a party, but rather anticipated that the party would develop out of the revolutionary struggle. ${ }^{207}$ Not creating a platform from which to operate, however, led to serious issues with organization and difficulties in creating a united front from which to lead the revolutionary movement.

Another significant party in the movement in La Convención was the Frente de la Izquierda Revolucionaria (Revolutionary Left Front- FIR). This was a grouping of the POR faction with which Blanco maintained ties, and the Leninist $\mathrm{CP}-\mathrm{a}$ splinter of the CP. ${ }^{208}$ The FIR was important because it disseminated propaganda to generate urban support for the movement, mobilized recruits, and conducted robberies to generate resources to fund the movement. ${ }^{209}$ It established an urban link to the rural struggle that created a wider base of social as well as monetary support.

\footnotetext{
204 Ibid.

205 Ibid.

206 Ibid.

207 Ibid.

${ }^{208}$ Zapata Bordeo headed the Leninist CP and had been affiliated with the FTC and the MIR (initially the APRA Rebelde- see previous chapter) and had been an active communist since his youth.

${ }^{209}$ Guevara, "Case Studies: Peru," 285.
} 
The FIR opposed the APRA's position in that it maintained a radical stance by disavowing the legitimacy and capacity of reform.

Blanco clearly reveals his animosity toward the APRA party and Haya de la Torre in arguing that it had: "degenerated into a liberal, anticommunist, procapitalist reform party. ${ }^{, 210}$ Despite this assertion, Blanco fails to explicitly identify when the APRA lost its revolutionary fervour, though it may have occurred sometime between 1938, when the APRA stopped referring to itself as Marxist, and 1946, when the POR was first formed in response to the perceived need for a workers' revolutionary party. Blanco and the FIR did not seek reform but rather to completely dismantle and restructure class relations not only in La Convención, but also throughout much of Peru. Within the party, however, there was also factionalism and disagreement over the means employed as well as over the desired outcomes of the revolution. The inability to create a cohesive ideological framework further demonstrates the fractured nature of the Left.

The factionalism of the movement resulted in what Blanco identifies as two streams of thought within the Leftist front: the Trotskyists with whom Blanco was affiliated, and the CP, who maintained a Stalinist perspective. The CP was highly critical and suspicious of Trotskyists and defined them as "agents of imperialism."211 According to Blanco, the CP program for change entailed the following: rental fees would not exceed 20 percent of the crop yield; a colonization plan similar to Beltrán's agrarian reform plan would be undertaken; land would be collectively purchased from landlords; and a reform program would be implemented that would expropriate lands

\footnotetext{
${ }^{210}$ Blanco., Land or Death, 159, n. 3.

211 Ibid., 43.
} 
based on pre-set purchase prices. ${ }^{212}$ This platform was in contrast to the Trotskyists, who deemed these measures as insufficient to create a balanced system that would be equitable to the indigenous peasant population.

The program that the Trotskyist party recommended was one that created a universal list of demands for the haciendas that would not function on a case-by-case basis, whereas the CP argued that each hacienda was different and therefore required distinct individual assessments. ${ }^{213}$ Secondly, the Trotskyist party sought to focus primarily on mass mobilization and only secondarily upon the legal system. While there was some consensus between the parties on this matter, they disagreed on issues regarding the election of candidates, as the $\mathrm{CP}$ recommended individuals who were highly literate, while the Trotskyists endorsed peasants who: "had demonstrated the most courage, the most interest in common problems, the most dynamism, regardless of whether they knew how to read." ${ }^{214}$ While there were differences between the CP and the Trotskyist bloc, the two were nevertheless able to coordinate, meet regularly, and apply pressure on both the government and the haciendas through the use of mass demonstrations. Understanding the tensions within the movement illuminates why Blanco was opposed to other socialist actors. Ideologically there were serious divisions between individual members and participatory groups.

Regardless of the dichotomies within the organization, by 1961 Blanco had helped establish 148 peasant unions and had launched a series of land seizures and strikes. ${ }^{215}$ Blanco argued that organizing the masses through unions was integral in

\footnotetext{
${ }^{212}$ Ibid., 45.

${ }^{213}$ Ibid.

${ }^{214}$ Ibid., 46.

${ }^{215}$ Contreras, "Struggles for Modernization," 166.
} 
leading a successful mass movement. He was strongly against the foco theory, which is a form of guerrilla warfare in which a small group of insurgents act in the mountains alone, with the aim of motivating the disgruntled masses to action. ${ }^{216}$ Foco theory was based primarily on Ernesto (Che) Guevara's experiences in Cuba in 1959. It was highly popular in Peru and many left-leaning intellectuals and agitators, such as Héctor Béjar, who conducted guerrilla activities based on foco theory, asserted the necessity of incorporating foco theory in the Peruvian movement in light of its "success" in Cuba. ${ }^{217}$ Blanco denied the plausibility of such activity, even in the face of criticism of other actors like Béjar who wanted to join efforts with Blanco. ${ }^{218}$ In a recent interview, Blanco reflects on the form that the movement took, stating that it was not a foco strategy, but rather: "In our case, the fight evolved as a collective imperative that had to be fulfilled. We didn't call ourselves a guerrilla force or an army, we called ourselves a 'syndicated brigade for agricultural defence' [sic]." ${ }^{219} \mathrm{He}$ argues that defining methodology in ideological terms is of little use, citing the fundamental difference as being the actions and tactics employed. Blanco's campaign was one based on collective action that sought consent to act and did not adhere to the

\footnotetext{
${ }^{216}$ Joshua Johnson, "From Cuba to Bolivia," Innovations: A Journal of Politics, Vol. 6, (2006): 26-32. Accessed June 27, 2012, from: https://afe.ucalgary.ca/innovations/files/innovations/Johnson\%20Cuba\%20to\%20Bolivia.pdf ${ }^{217}$ Hugo Blanco, "An Interview with Hugo Blanco Glados," interview by Alan Ramón Ward, International Journal of Postcolonial Studies, 13.4 (2011): 651-663. http://dx.doi.org/10.1080/1369801X.2011.628153

It is debated whether foco theory was the reason that the Cuban Revolution was successful therefore calling into question the applicability of foco theory and its success. For example, Joshua Johnson argues that it was not the method that Guevara conducted guerrilla warfare that caused the Cuban Revolution to be successful, but rather that: "the economic, social, and nationalistic forces combined to the benefit of Guevara and Castro." Johnson, "From Cuba to Bolivia," 26.

${ }^{218}$ Blanco, "An Interview with Hugo Blanco Glados," 652. "Béjar, like Régis Debray, would later realize that he had underestimated the importance of mass work."

${ }^{219}$ Ibid., 660.
} 
principals of foco theory. His ability to unify the majority of the peasants inevitably led to the relative success of the insurrection in La Convención. ${ }^{220}$

In 1961, the FIR also became integral to the movement in La Convención when it coordinated militants under the motto: tierra o muerta (land or death). ${ }^{221}$ The recruitment process undertaken by the FIR was, however, too hasty and resulted in poorly trained recruits. He argues that: "Tasks of this nature can be successfully carried out only by comrades of iron, of a fully tested moral fiber. ${ }^{222}$ In addition, the hesitation of the POR faction in forming a party platform inevitably led to its demise. Blanco thinks that, because of the lack of a consolidated party framework, there was no guarantee that the movement would work, as there was no guiding ideology or platform that informed action in a united manner. ${ }^{223}$ Significantly, by March 1962 , disagreements within the movement and how it should be carried out reached new heights.

Blanco demanded that a national congress of the FIR be called in Cuzco to coordinate action. The response from other actors was lackluster and Blanco responded by threatening to assume total command over the movement. Hugo Bressano, also known as Nahuel Moreno, who was head of the Argentinean

\footnotetext{
${ }^{220}$ Blanco does not view this uprising as a success, however, as mentioned, Hobsbawm has deemed this the most important not only Peru, but in all of South America. Other scholars, such as Leon G. Campbell in "The Historiography of the Peruvian Guerrilla Movement, 1960-1965" also points to the success of the movement.

${ }^{221}$ Tom Brass, "Trotskyism, Hugo Blanco and the ideology of a Peruvian peasant movement," Journal of Peasant Studies 16.2 (1989):177. http://dx.doi.org/10.1080/03066158908438389

${ }^{222}$ Ibid.

${ }^{223}$ Blanco, Land or Death, 39.
} 
Trotskyist party, dismissed Blanco from all of his leadership positions. ${ }^{224}$ With

dwindling support from within the parties (SLATO, FIR, FTC), Blanco returned to La

Convención and ran for secretary general of the FPCC. While he had almost

unanimous support from the allegados and sub-allegados, the arrendires, in an attempt

to thwart Blanco's win, withdrew from the federation. ${ }^{225}$ Despite waning support,

Blanco called for a redistribution of uncultivated land to be allocated to the poorest

peasants: the arrendires and allegados. ${ }^{226}$ This rallying call resulted in a violent clash

in La Convención, to which the Guardia Civil (Peruvian National Police) responded

with force. ${ }^{227}$ With few political allies, Blanco was only able to evade the Guardia

Civil for a limited time and was captured in May $1963 .^{228}$ Both the Guardia Civil and

the Intelligence Police (PIP) had been sent to capture Blanco. ${ }^{229}$ The Guardia Civil

had orders to kill Blanco upon sight and the PIP had been ordered to capture him

alive. He states that: "The ones who discovered, bound, and imprisoned me were PIP

soldiers; the Civil Guard official who came up to me after[...]had to content himself

with hitting me on the head with his rifle butt."230 Had the Guardia Civil found him, it

${ }^{224}$ Guevara, "Case Studies Peru," 285. Blanco records that after the POR returned from exile, it was the faction that: "belonged to the tendency which at that time called itself orthodox, and was strongly influenced by the Argentinian Trotsky party. It was in that party, among whose leaders Naheul Moreno particularly stood out, that I acquired my Marxist education," Blanco, Land or Death, 19. Moreno was named the secretary general of the Latin American Orthodox Trotskyism (SLATO) in 1957. In 1961 SLATO moved its head quarters to Lima, and by 1962 Moreno moved permanently to Lima in an attempt to prevent a guerrilla campaign from consuming the party.

${ }^{225}$ Guevara, "Case Studies: Peru,", 285.

${ }^{226}$ Ibid., 86.

${ }^{227}$ In one encounter Blanco shot and killed a police officer, which only intensified the manhunt for Blanco.

${ }^{228}$ Ibid.

${ }^{229}$ Blanco, Land or Death, Blanco records his capture as occurring when he met a boy, Mario Huamán, "who showed great solidarity" and travelled to Cuzco to get in contact with the FIR. The FIR was reorganizing and had been infiltrated, leading to the capture and torture of Mario, who eventually informed the police where Blanco was hiding and was forced, under the threat of death, to guide them to him, Reprisals were planned against Huamán, which Blanco condemned and called off, 90.

${ }^{230}$ Ibid. He further states that often: "to kill us legally presents certain difficulties, and so [they] prefer direct assassination." 
is highly likely that he would have been assassinated on the spot. The inability to create a cohesive party in addition to the impulsive nature of the movement resulted in his capture.

Blanco was subsequently tried by a military tribunal, sentenced to death and transferred to El Frontón prison. Trotskyists in Peru, and labour unions around the world, petitioned for the release of Blanco and began to take measures to have the sentence reversed. This international effort will be discussed in greater detail in the subsequent chapter. It is important to note, however, that the context in which the international community participated was inherently socialist. The socialist nexus was not linear or cohesive but rather fractured and ideologically divided. The nature of the movement that Blanco led demonstrates the extent of this factionalism. By analyzing the rationale out of which the movement arose, it becomes clear that there was an imbalance in land holding patterns that created a situation in which the government of Peru, while employing coercive measures, was forced to enact reforms.

The unionization of the peasantry and the subsequent actions they took led to the first agrarian reform law, passed by Ricardo Pérez Godoy. While the reform was highly limited and did not extend to all of Peru, the change in La Convención became the model that would be applied by various governments throughout the next decade. As will be discussed in Chapter Three, the cooperative framework that was institutionalized by Velasco Alvarado in 1968 was also applied by NGOs as well. Yet the restricted nature of the reforms, continued US influence, and the general maintenance of the existing power relationships throughout the 1960s gave rise to guerrilla movements. These movements, however, varied significantly from the initial 
campaign led by Blanco. For example the MIR, in tandem with the ELN, conducted a foco operation in 1965 on the Mesa Pelada plateau in the Andes close to La Convención. As previously discussed, Fernando Belaúnde Terry crushed this insurrection. However, by the 1980 s, the Sendero had established a strong guerrilla campaign that continues to have influence in Peru, which, although dwindling in support, indicates that Leftist movements in Peru were resilient.

While Blanco and other leftist agitators were exiled, jailed, and at times murdered throughout the Cold War, they were able to maintain a foundation in Peru. The attempts to subdue them did, however, create fractures within the parties, as was evident with the POR, which rendered many of the movements weak and factionalized. While the division of the parties affected the relative success of the leftist campaign, it also created situations forcing the government to act, not only through the use of military force, but also through the establishment of reforms aimed at easing tensions. As Tanya Korovkin demonstrates, the resulting cooperatives were part of a more general process of social, economic, and political change occurring in Peru since the end of World War II. ${ }^{231}$ However, she contends that the cooperative movement began under Velasco Alvarado and not with the movement led by Blanco in La Convención in the early 1960s. While under Velasco Alvarado's rule the government managed to institutionalize cooperatives, the initial movement directed by Blanco presents a more accurate time frame for the beginning of the cooperative movement as it was in response to this struggle that, for the first time, the government

\footnotetext{
${ }^{231}$ Tanya, Korovkin, "The Politics of Agricultural Cooperativism: Peru, 1969-1983," (PhD dissertation York University, Toronto, ON 1986), http://search.proquest.com/docview/250094723?accountid=9894.
} 
was forced to take action and recognize the inequitable conditions between the impoverished and the elite.

The reforms that Velasco Alvarado legislated are an important epoch in Peruvian history, as the formation of cooperatives across Peru has typically been deemed one of the most "radical" in all of Latin America. ${ }^{232}$ He enacted rules limiting the extent of land an individual could own, and by July 1976, had seized roughly one fifth of all domestic farmland, which he redistributed to new owners. ${ }^{233}$ This land was typically reorganized into production cooperatives that were centrally managed by the government, thereby reshaping capitalist enterprises into collective production units. ${ }^{234}$ While the reforms that Velasco Alvarado sanctioned were intended to restructure land holding patterns, many of the same disparities persisted, which eventually led to the demise of the cooperative movement. ${ }^{235}$ While the cooperative movement under Velasco Alvarado was different from the demands of Blanco and the successive socialist movements, Blanco and the left movements created the context in which Velasco Alvarado was able to act.

\footnotetext{
232 Ibid., 56.

233 Ibid.

${ }^{234}$ Ibid., 59-60.

${ }^{235}$ The reasons for this are will beyond the scope of this paper, but for a further explanation see Korovkin, "The Politics of Agricultural Cooperativism.” Also see: François Praline Coupal, "Contradictions of the Peruvian Experiment: Through the Optic of Agrarian Reform and Agricultural Cooperatives" (Master of Arts in International Affairs thesis, Carleton University, Ottawa, ON 1984).
} 


\section{Changes to the Canadian Political Landscape: The Pearson and Trudeau Years}

In Peru, as in much of Latin America, there was a strong socialist current that, even though at times was suppressed, maintained a foothold in the political and intellectual landscape. The nature of these movements and ideologies was not, however, a cohesive linear development but rather a nexus of interactions and associations. The socialist connections and affiliations did not only apply to the local Peruvian context but were connected to the international realm as well. As will be demonstrated, Canadian NGOs (and NSAs) participated in the Peruvian socialist milieu through international development projects that coincided with the socialist agenda, which was promoted by Velasco Alvarado, and his leftist military junta. In addition, Canada was also part of the nexus through advocacy by various unions and institutions with the aim of freeing Hugo Blanco. A consideration of Canadian nonstate involvement in the Peruvian socialist sphere of influence contributes to the study of Cold War relations as it moves beyond traditional inter-state relations as characterized in the literature. Moreover, given the increasing role of development of the period, this type of approach provides important insight beyond governmental bodies and inter-state relations by connecting states through NGOs and NSAs, which inevitably are representatives of their home nation.

The influence and presence of NGOs was significant during the Cold War in Latin America, indeed even globally. As Suri argues, beginning in the 1960s, NGOs, along with other NSAs, assumed a prominent role in international relations as governments and populations became disillusioned with traditional Cold War 
ideologies and institutions. ${ }^{236}$ The growing relevance of NGOs is further depicted in the Pearson Report, Partners in Development, published in 1969 and a White Paper, Foreign Policy for Canadians, published in $1970 .^{237}$ While these two reports cannot singlehandedly demonstrate the course that Canadian and international development policies and thinking followed, they do confirm the premise that, beginning in the 1960s, development acquired a more important role in the Cold War context. They both call for a dramatic increase in developmental assistance. While both of these reports focus on the role of nations, they provide a gauge for understanding the increase in attention being given to development, not only nationally but beyond states, as citizens and NGOs assumed a significant role on the international stage. A review of the evolving role of development, in conjunction with a consideration of the Canadian political landscape, will demonstrate the significance of development institutions during the Cold War. By establishing the Canadian context, it will become possible to place Canadian development and advocacy practitioners into the Peruvian socialist nexus.

Lester B. Pearson was Canada's Prime Minister (PM) between 1963 and 1968. He is remembered for numerous achievements including, but not limited to, his participation in the founding of the 1950 Colombo Plan, and his successful negotiation of the Suez Crisis, for which he was awarded the Nobel Peace Prize. ${ }^{238}$ Further, upon his retirement as PM, he was commissioned by the World Bank to lead an investigation on global development, which culminated in the Pearson Report.

\footnotetext{
${ }^{236}$ Jeremi Suri, "Non-governmental organizations and non-state actors," in Palgraves Advances in International History ed. Patrick Finney, (New York, NY: Palgrave Macmillan 2005): 239.

${ }^{237}$ Pearson et al., Partners in Development.

${ }^{238}$ For more information on Pearson's life and achievements see: Robert Bothwell, Pearson: His Life and World, (Toronto ON: McGraw-Hill Ryerson Limited 1978).
} 
Nationally, while the External Aid Office (EAO) was established in 1960, it was not until Pearson came to power in 1963 that "official demeanour changed" and the aid program was fully launched. ${ }^{239}$ With respect to Latin America specifically, the EAO also created a regional aid program. ${ }^{240}$ This was significant, as Morrison notes, because little more could have been achieved in the early 1960s as: "Foreign aid was still a novel, relatively marginal government activity. ${ }^{.241}$ Under Pearson, and Herbert Moran (Director of the EAO), there were significant attempts to expand governmental development assistance.

The increase of assistance at this time must be considered in the Cold War context. The increase of loans and grants made through the EAO occurred as a response to security concerns that derived from the perceived threat of communism. ${ }^{242}$ Policy was created not only with development in mind, but also included security dimensions. Balancing development and security was seen as a model that would limit the influence of Moscow. ${ }^{243}$ Moreover, assistance was marginal and faced significant organizational issues in the early years, which inhibited the extent and success of the assistance that was distributed. ${ }^{244}$ Despite these contradictions and issues that Canadian foreign aid faced, the increase in aid, in particular to Latin America, points to a changing perception of international development.

\footnotetext{
${ }^{239}$ Ibid., 44 \& 46.

${ }^{240}$ Morrison, 51.

241 Ibid., 56.

242 Ibid., 27.

${ }^{243}$ Rochlin, 33-7. He argues that it was not socialism per se that was a perceived threat in Latin America, but rather that socialism: "was not a problem if it avoided alignment with Moscow and if it did not threaten Canadian capital. Thus, for example, Canada supported Peru's APRA movement and its founder Haya de la Torre," 36.

${ }^{244}$ Morrison, 51.
} 
In August 1968 Lester B. Pearson accepted a commission from the World Bank President, Robert S. McNamara. Pearson was tasked with reviewing the history of development over the past twenty years, analyzing the results, consequences, and limitations of development assistance, and recommending policies for improving the distribution and application of aid in the future. ${ }^{245}$ On September 15, 1969 Pearson and his colleagues submitted the report, Partners in Development. This report was based not only on documentation from development organizations, but included viewpoints from both donor and recipient countries. ${ }^{246}$ While there was an attempt by Pearson and the committee to conduct a comprehensive review of all countries, it seems significant that information from communist countries is missing. The report acknowledges this omission but concludes that: "IIt would, of course, be most helpful to the cause of international development if Communist and non-Communist countries could work together more closely in this field. The Commission ventures to hope, therefore, that this will increasingly be the case." 247

The exclusion of communist countries, but stated aspiration to work with them, is indicative of changing perceptions and attitudes in the Cold War context. Rather than maintaining a position of total opposition, the commission concedes the necessity of working with, rather than against, communist countries. Generally, this report evokes a sense of a global community and the need for international cooperation that attempts to at least rhetorically move beyond the notion of two hostile Cold War blocs. In addition, the report asserts that there was a need for an increase in aid internationally, and suggested that official aid (distributed from

\footnotetext{
${ }^{245}$ Ibid., vii.

${ }^{246}$ Ibid.

${ }^{247}$ Ibid., ix.
} 
governmental bodies) granted by countries should amount to 0.70 percent of GNP and total aid (including aid from the private sector) 1 percent of GNP by $1975 .^{248}$ This justification for an increase in aid demonstrates that, while governments did not necessarily agree with, or implement the targets, there was increasing attention being given to the expansion of international aid.

While led by a former Canadian Prime Minister, the commission's findings were not necessarily reflective of Canadian views of development or action throughout the 1960 s and into the 1970 s. Yet, a review of governmental attempts and responses to expand development for this period is useful in establishing the Canadian context out of which NGOs, such as Oxfam, and other organizations extended support to foreign states, such as Peru, and how development practices were being reconfigured. A review of the trajectory of the Canadian International Development Agency (CIDA) will also provide insight into the increasing importance of development during this period. As will be demonstrated, Latin America by the 1970s was becoming an important region with respect to Canadian foreign interests and foreign policy was becoming rhetorically sympathetic toward key Latin American countries. ${ }^{249}$

The increase in developmental aid established under Pearson was further continued under Trudeau, Canada's PM from 1968-1979 and 1980-1984. Upon coming to office he conducted a review of foreign policy, which was published in

\footnotetext{
248 Ibid.

${ }^{249}$ This will be discussed in greater detail shortly. The majority of this argument derives from James Rochlin, Discovering the Americas: The Evolution of Canadian Foreign Policy Toward Latin America, (Vancouver BC: UBC Press 1994); Morrison's Aid and Ebb Tide.
} 
1970 in a White Paper, Foreign Policy for Canadians. ${ }^{250}$ Further, the EAO was restructured and became CIDA in 1968. Additionally, while still under the EAO a NGO division was created to provide funding in the form of grants to NGOs that aligned with government priorities. ${ }^{251}$ Typically, these concerns related to food, education, community development, and water aid/projects. ${ }^{252}$ While this division connected the government to private NGOs, little attention will be given to the loans distributed here, as these projects are not explored in this thesis. ${ }^{253}$ The significant expansion of CIDA and the White Paper, which will subsequently be considered, point to the increasing role of development during this period, government issued or otherwise.

Mitchell Sharp, the Secretary of State for External Affairs, headed the review of foreign policy that culminated in the White Paper Foreign Policy for Canadians. The paper asserts that foreign policy should be an extension of national policy, foreign pursuits should conform to Canadian ideals, and policy should be implemented for the enhancement of economic growth in Canada. ${ }^{254}$ The White Paper was subsequently followed by an additional report in 1972: "Canada/U.S. Relations: Options for the Future," also under the auspices of Sharp. It is typically referred to as the 'Third Option. ${ }^{, 255}$ The policy paper from 1972 asserted that there were three options that Canada could pursue on the international stage. First, Canada could

\footnotetext{
${ }^{250}$ Department of External Affairs, "Foreign Policy for Canadians" in Foreign Policy for Canadians by Mitchell Sharp, (Ottawa, ON: Queens Printer,1970).

${ }^{251}$ Morrison, 68-69.

252 Ibid.

${ }^{253}$ For further information on this division see Morrison. For specific reference to Latin America see Rochlin. ${ }^{254}$ Ibid.

${ }^{255}$ Department of External Affairs, Canada/U.S. Relations: Options for the Future," International Perspectives, by Mitchell Sharp, (Ottawa, ON: Queens Printer, special issue,1972).
} 
maintain its relationship with the United States as it was; second, Canada could attempt to create a more integrated relationship with the United States; or third, Canada could: "pursue a comprehensive long-term strategy to develop and strengthen the Canadian economy and other aspects of its national life and in the process reduce the present Canadian vulnerability. ${ }^{, 256}$ The pursuit of a more diversified international presence was the route that Canadian policy generally followed. ${ }^{257}$ Specifically, the 1972 paper states that, as the world situation evolved, there would be more opportunities for Canada and the US to foster relations with Communist and developing countries. ${ }^{258}$ This explicit aim to develop international relations with Communist states had been implemented in the establishment of diplomatic relations with Communist China in 1969.

Throughout the White Paper, there is a constant assertion that Canada is distinct from the United States. For instance, the paper states that a policy review was required as increasing criticism over the Vietnam War stemmed from the continuous alignment of Canadian policy with the foreign interests of the United States. ${ }^{259}$ The paper maintains this stance and argues for greater autonomy in Canadian policy, even if in opposition to the way in which the American Government conducted inter-state

\footnotetext{
${ }^{256}$ Ibid., 1.

${ }^{257}$ Jeremy Kinsman, "Who is My Neighbour? Trudeau and Foreign Policy," International Journal 57.1 (2001/2001): 55-77. Accessed July 11, 2012 from: http://www.jstor.org/stable/40203633. See also: David Malone, “Foreign Policy Reviews Reconsidered," International Journal 56.4 (2001): 555-578. Accessed July 7, 2012 from: http://www.jstor.org/stable/40203604.

${ }^{258}$ Department of External Affairs, "Canada/U.S. Relations: Options for the Future," 1.

${ }^{259}$ Department of External Affairs,, "Foreign Policy for Canadians," 7.
} 
relations. ${ }^{260}$ In regards to Latin America specifically, the paper argues that the United States had always maintained a close relationship of its own with Latin American countries, one in which Canada had limited involvement. The limits of Canadian involvement were partially a consequence of the geographical reality that the US divided Canada and Latin America, which inhibited Canada from establishing closer ties of its own with Latin American countries. ${ }^{261}$ The report affirms that Canada usually acts as the mediator between the United States and Latin America, which poses a challenge for Canadians when trying to maintain their own cultural and entrepreneurial identity as distinct from the United States. ${ }^{262}$ The constant assertion that Canada is separate from the United States demonstrates that the Canadian government sought to distance itself from the policies of the United States. The authors' views on Latin America further demonstrate the desire to create stronger relations with Latin American states.

The White Paper, in addition to insisting on distancing Canadian from American foreign policy, also maintains the need for international cooperation and development. The main themes pursued throughout the document are: economic growth, sovereignty and independence, international peace and security, social justice, betterment of quality of life, and protection of the natural environment. ${ }^{263}$ These themes, the paper argues, should be applied to both the national and

\footnotetext{
${ }^{260}$ The rationale and background on Canadian/American relations are highly complex and are beyond the scope of this paper. For a review of Canadian/American relations at this time see: J.L. Granatstein and Robert Bothwell, Pirouette: Pierre Trudeau and Canadian Foreign Policy (Toronto, ON: University of Toronto Press). In particular see "PART TWO: Errand in the Wilderness: Canada and the United States," 39-76.

${ }^{261}$ Department of External Affairs, "Latin America," in Foreign Policy for Canadians by Mitchell Sharp, (Ottawa, ON: Queens Printer, 1970): 5.

${ }^{262}$ Ibid., 6.

${ }^{263}$ Department of External Affairs, "Foreign Policy for Canadians", 14-16.
} 
international realms. Moreover, the paper contends that: "there is likely to be a slow evolution toward a more liberal communism,"264 indicating that Canada recognized that the threat of communism was diminishing. ${ }^{265}$ Given these general premises, the authors do not foresee the necessity to create a foreign policy either in tandem with the United States or as a force to counteract communism. Rather, the policy recommendations focus on creating international cooperation that respects Canadian and foreign sovereignty.

While the White Paper's policy recommendations were not necessarily followed to the letter, there was a clear attempt to create foreign policy that was respectful of foreign governments, yet one that protected and conformed to Canadian standards. On Latin America, the paper's authors assert that closer relations that were premised on the mutual respect would be ideal, and would inevitably enhance Canadian sovereignty and independence. ${ }^{266}$ Significantly, the report argues that: "the form of government and the kind of social organization existing within a national state is the prerogative of that state. $" 267$ That the Canadian government was explicitly stating (even if not fully implementing the policy) that it was willing to conduct relations with states, regardless of the form of their national government (communist, non-communist, and so on), further exemplifies a shift in Cold War ideology.

There is an attempt in the White Paper to explicitly link Canadian and Latin American history that informs the conducting of reciprocal relations. The paper argues that Canada and Latin America share a similar history, particularly pertaining

\footnotetext{
${ }^{264}$ Ibid., 21.

${ }^{265}$ Ibid., 22.

${ }^{266}$ Department of External Affairs, "Latin America", 6.

${ }^{267}$ Ibid., 11.
} 
to their indigenous populations. It is suggested that, as Canadians address national issues and become aware of social and economic issues in Latin America, there would be an exchange of knowledge that would benefit both Canada and the respective Latin American country. ${ }^{268}$ It was thought that this would occur through shared cultural and economic exchanges. ${ }^{269}$ Rather than attempting to impose specific styles of governance upon the recipient nation, the paper is oriented toward increasing economic potential between Canada and Latin America.

Development policies were the intended framework that would create economically beneficial relationships between Canada and Latin America. The intent to create closer international relations did not mean that Canada would support regimes that promoted. On peace and security in Latin America, the paper suggests that two main threats existed and outlined how Canada should respond. ${ }^{270}$ The first threat was identified as the possibility of inter-state conflict, while the second threat was the potential of intra-state conflict emerging from revolutionary factions across Latin America. The report suggests that: "Canada's basic role in this regard would appear to be to do what it can to assist those who are striving to remove the potential causes of violent revolution in the hemisphere."271 Absent from this statement is the threat of communism, further indicating that there was a shift in Cold War attitudes. Morrison attributes the omission of "communism" to Cold War sensibilities, and points out that the term was present in a discussion paper that preceded the White

\footnotetext{
${ }^{268}$ Ibid.

${ }^{269}$ Ibid., 6-7 and 11-13.

${ }^{270}$ Ibid., 19.

${ }^{271}$ Ibid.
} 
Paper. ${ }^{272}$ Yet the paper is primarily focused on aid, and security is give only cursory mention. ${ }^{273}$ The focus on aid rather than security, by 1967 , led to what Rochlin asserts was a position in Latin America that was distinct from the US. ${ }^{274}$ While the impact of the White Paper was highly limited, and did not necessarily reflect action, there was a growth of interest in and connections with Latin America.

The increase in interest and presence in Latin America is also evident in the debate over joining the Organization of American States (OAS) ${ }^{275}$ and the creation of stronger trading relationships with Latin American countries. The White Paper suggests that there were various advantages for Canada to join the OAS; for instance, it would strengthen Canadian/Latin American relations, while increasing Canada's economic advantage. Moreover, it would allow Canada to have a greater input in questions relating to the security and defense of the southern hemisphere. Despite these advantages, the White Paper goes on to list numerous disadvantages as well. First, the OAS would absorb any development aid that Canada sought to distribute to Latin America, as the OAS had its own development organizations and objectives. Second, cultural, scientific and technological exchanges would similarly be directed

\footnotetext{
${ }^{272}$ Morrison, 93.

${ }^{273}$ Ibid.

${ }^{274}$ Rochlin, 33.

${ }^{275}$ For more information on the OAS see: Foreign Affairs and International Trade Canada, "The Organization of American States (OAS)", last modified June 1, 2012, accessed July 10, 2012 from: http://www.oas.org/en/ The OAS held its first official conference between 1889 and 1890 in Washington, and implemented its Charter in 1951. Article 1 of the Charter outlines the objectives of the OAS. The organization is intended to foster peace and justice, to promote solidarity, to strengthen collaboration, and to defend their sovereignty, territorial integrity, and independence. "The Organization uses a four-pronged approach to effectively implement its essential purposes, based on its main pillars: democracy, human rights, security, and development." Moreover: "Although some scholars trace the antecedents of the inter-American system back to the Congress of Panama convened by Simón Bolivar in 1826, the fact is that it was only in 1889 that the American States decided to meet periodically and to forge a shared system of norms and institutions. There were, in the meantime, conferences and meetings that attempted to give birth to the system, but it was only at the invitation of the Government of the United States that the process began that was to continue uninterruptedly until this day."
} 
through the OAS, as it had established agreements through academic and other training institutions. And, finally, while there might have been security and defense advantages, the paper states that in joining the OAS there were political and economic obligations that would inhibit Canada from acting in its own interests. For example, had Canada been a member in 1964, it would have been obliged to sever relations with Cuba. ${ }^{276}$ Despite the potential security benefits to be gained by joining the OAS, the Canadian government would be forced to act in tandem with other foreign policy interests and would therefore be greatly limited by being a member. The paper concludes by arguing that, rather than joining the OAS, Canada should work toward fostering stronger Latin American relationships on a country-by-country basis. ${ }^{277}$ This conclusion further demonstrates that the Canadian government sought to create a foreign policy that allowed Canada to pursue its own interests. ${ }^{278}$

There was also a focus on both aid and trade within the paper. The policy paper asserts that aid programs for Latin America should not only be continued, but also expanded both bilaterally - aid given directly to a country - as well as multilaterally - aid given to an organization that distributes it. A stronger trading relationship between Canada and Latin America was also recommended in the report. To foster stronger trading relationships, the report advised that alternate shipping routes to Canada be considered, either via the sea or air, to create a more direct link between Canada and Latin America, thereby allowing greater freedom of trade by

\footnotetext{
${ }^{276}$ Department of External Affairs, "Latin America"., 23. Canada maintained relations with Cuba, during the Cuban Revolution (1953-1959) and even after Cuba joined the Soviet Bloc.

${ }^{277}$ Foreign Affairs and International Trade Canada, "The Organization of American States (OAS)": Canada became a "permanent observer" in 1972, and a full member in 1990.

${ }^{278}$ While Canada did not become a full member until 1990, there was much debate over whether to join or not. While some opposed, many supported the idea of becoming a member. For more information on this debate, see Rochlin, 59-62.
} 
avoiding transportation through the United States. ${ }^{279}$ Moreover, the report asserts that, while international agreements had been established for the trade of coffee, sugar, tin and wheat, all of which were produced by Latin American countries, the Canadian Government intended to expand the agreements to various other commodities not included in existing agreements, but produced in Latin America. ${ }^{280}$ The intent was to foster closer economic relations between Canada and Latin America by expanding trade agreements on certain commodities of interest to both regions. An increase in trade would also give rise to the development of closer diplomatic relationships on a bilateral basis between Canada and respective Latin American countries. Given the potential to foster closer economic and diplomatic relations through trade, it is not surprising that it was the programme given the most attention in the report.

While the White Paper was intended to be a comprehensive review of foreign policy, it was ultimately unable to influence aid programs or elicit a response from the Canadian public. ${ }^{281}$ Overall, the report was vague, toned-down, and had little effect. $^{282}$ It also received criticism from Pearson, who was outraged by the White Paper and the narrow focus of national self-interest in the pursuit of international relations. ${ }^{283}$ Beyond these criticisms, generally, under Trudeau there were significant attempts to break the antagonisms between the two Cold War blocs. ${ }^{284}$ International development assumed further relevancy and grew, even if concentrated and

\footnotetext{
${ }^{279}$ Ibid., 31 .

280 Ibid.

${ }^{281}$ Morrison, 96. Also see: J.L. Granatstein and Robert Bothwell, Pirouette: Pierre Trudeau and Canadian Foreign Policy (Toronto, ON: University of Toronto Press, 1990), 39.

${ }^{282}$ Ibid., 95-6.

${ }^{283}$ Granatstein and Bothwell, 34.

${ }^{284}$ Ibid.
} 
limited. ${ }^{285}$ While there were certainly shortcomings in Canadian development abroad, there was undoubtedly a shift and increasing focus on the necessity and legitimacy of international aid. This shift in Cold War mentality is important for understanding the context out of which private organizations, such as Oxfam and labour unions, participated in foreign countries. Moreover, the increased attention on government aid was paralleled by an increase of nongovernmental aid, and by 1975, fifty-four NGOs were operating in Latin America. ${ }^{286}$ While these organizations were not officially affiliated with the Canadian government, they were part of a Canadian public outreach that participated in international relations.

${ }^{285}$ Ibid., 262. Also see Morrison and Rochlin.

${ }^{286}$ Rochlin, 96. 
Canadian NGOs and NSAs in the Peruvian Socialist Nexus

Under Pearson and Trudeau, Canadian foreign policy and views of

development assumed new meaning. Particularly under Trudeau, aid packages

expanded and there was a cooling of international relations. These attempts were not

always successful and at times he was much criticized by parliamentary members, particularly in reference to Foreign Policy for Canadians. Criticism of the White Paper is also evident in an exchange of letters between Trudeau and Oxfam Canada's Committee on Government Aid. ${ }^{287}$ Oxfam suggests that, as Canada was reviewing development assistance policies, the government should revise the policies based on the Pearson report, stating that Canada: "should increase its official net disbursements for aid to $0.70 \%$ of its GNP $[\ldots]$ the tying provisions relating to Canadian procurement should be greatly loosened or removed without delay" and that Canada should adopt all of the Pearson Reports findings on trade policy. ${ }^{288}$ These recommendations included making concessions to "developing" countries and the creation of a trading model that would serve as a global template so that Canada

\footnotetext{
287 "Background Paper on the History of the Development of the Government Aid Committee, Oxfam of Canada," box 7, file 5, "Papers: History of the Government Aid Committee, n.d.," Oxfam Canada, Library and Archives Canada, Ottawa, ON. This committee was only in existence for a short number of years, 1969-1971. The committee was formed to conduct individual analysis on the Pearson Report, "Partners in Development" and to advise possible avenues of action by Oxfam in light of the report; research policies being implemented by the Canadian International Development Agency (CIDA) and determine where CIDA and Oxfam could cooperate; and to investigate Canadian tariff laws in the Caribbean (this final point was to be given the least priority and the first two aims were given priority. By June 1970 the committee had essentially dissolved. The final meeting was held June $23^{\text {rd }}$, during which the committee, under advice of the Executive Committee, reexamined its "purposes and functions" and decided that the committee should become a "strategy group;" but the committee would remain intact until the strategy group had became established. In September 1970 the Information Officer of the committee, Miss Freeman, resigned from Oxfam, and "it appears that after her departure the committee became totally inactive" (10-11). There were a series of attempt to resurrect the committee, however, due to circumstances in South-East Asia, all resources were directed to raising funds (14).

288 "A Letter From Oxfam of Canada's Committee On Government Aid to Prime Minister Trudeau Concerning Canada's External Aid \& Trade Policies And His Reply," box 7, file 1, "Papers: Committee on Government Aid, 1969-1971," Oxfam Canada, Library and Archives Canada, Ottawa, ON.
} 
would assume a leadership role by pushing for broader and more equitable agreements between countries than had been previously established. ${ }^{289}$

Prime Minister Trudeau replied to Oxfam's letter, and while the development assistance policies were still under review, he provided some assurances that their suggestions would be taken into consideration. He stated that, while an increase in development aid was pertinent, the quality of the aid being granted was equally important. ${ }^{290}$ The establishment of the International Development Research Center (IDRC) in 1970 was intended to ensure that more effective aid programs were being developed through knowledge sharing. ${ }^{291}$ Moreover, Canada was participating in negotiations with the United Nations Conference on Trade and Development, which sought to coordinate domestic and international development. ${ }^{292}$ The establishment of the IDRC and participation in conferences on trade were intended to indicate that Canada was working toward the goals set out in the Pearson Report and that Canada was assuming a leadership role. While no concrete promises were made in the letter, Trudeau states that: "In my opinion the present trends of the Canadian aid programme and the recommendations of the Commission for International Development show a remarkable degree of harmony." 293 The generally positive outlook of the Prime Minister and the absence of any mention of communism by either Oxfam or Trudeau

\footnotetext{
${ }^{289}$ Ibid.

${ }^{290}$ Ibid.

${ }^{291}$ International Development Research Centre, “About Us," accessed July 28, 2012 from: http://www.idrc.ca/EN/AboutUs/Pages/default.aspx ${ }^{292}$ United Nations Conference on Trade and Development, "A Brief History of UNCTAD." (Last modified 2012). Accessed July 11, 2012, from: http://unctad.org/en/Pages/About\%20UNCTAD/ABrief-History-of-UNCTAD.aspx. "In the early 1960s, growing concerns about the place of developing countries in international trade led many of these countries to call for the convening of a full-fledged conference specifically devoted to tackling these problems and identifying appropriate international actions."

${ }^{293}$ "A Letter From Oxfam of Canada's Committee On Government Aid to Prime Minister Trudeau."
} 
further demonstrates that, while the Cold War was ongoing, there was nevertheless a concerted effort by the Canadian government and NGOs to move beyond the traditional bipolar rhetoric and instead focus on international issues beyond the threat of communism.

The Oxfam report is critical of the White Paper and asserts that Foreign Policy for Canadians maintains a laissez-faire attitude toward global development. Oxfam argued that: "The Government appears to recognize that most Canadians would favour a foreign policy which actively seeks to promote greater international harmony, but the White Paper has deliberately retreated from such a policy into a more isolationist stance. ${ }^{294}$ Oxfam contends that the emphasis on sovereignty is misguided and that the concept of a nation state engaged in activities solely in its own interest is anachronistic. ${ }^{295}$ Rather, as the report states, nations are part of a global community that pursue a variety of interests beyond the interests of a single nation. In addition, Oxfam accurately points out that: "the emphasis on sovereignty in the White Paper has been conceived too much in the narrow context of the domination of Canada economically and politically by the United States."296 This constant assertion of Canadian sovereignty is perhaps overstated in the White Paper, but is evidence of a changing perception of the US and perceived need to create a distinctly Canadian image.

Oxfam further argues that the White Paper overemphasizes Canadian economic development, which would further widen the gap between the rich and the

\footnotetext{
294 "A Submission to the Parliamentary Committee on External Affairs re: The White Paper on Foreign Policy," Prepared by Oxfam Canada, January 28, 1971, box 7, file 4, "Papers: White Paper on Foreign Policy, 1970-1972," Oxfam Canada, Library and Archives Canada, Ottawa, ON., 5.

${ }^{295}$ Ibid., 6.

${ }^{296}$ Ibid., 8.
} 
poor globally as the trading policies it envisioned were short-sighted. ${ }^{297}$ However, the White Paper did pay particular attention to the creation of trading relationships that were intended to be mutually beneficial. In the period 1968-73, Rochlin records that Canadian exports to Latin America rose eighty-three percent, and imports from Latin America were up one-hundred-and-five percent. ${ }^{298}$ Moreover, while there was an emphasis on international development in the White Paper, it maintains that development could only be attained through the establishment of trade policies that would seek to limit tariffs and create a more balanced system of trade. Oxfam views the trade policies outlined in Foreign Policy for Canadians as unbalanced, as the emphasis placed on Canadian economic growth reveals distorted considerations of human development and social justice. ${ }^{299}$ Oxfam argues instead that aid should be increased to the level recommended by the Pearson Report. Development aid was slated by the White Paper to increase, although not to the extent that Oxfam deemed appropriate. Indeed, while bilateral aid had quadrupled between 1970-6, it only represented six percent of all aid that was disbursed. ${ }^{300}$

Ultimately, Oxfam concludes by stating that the priorities of the White Paper required adjusting, and that social justice and quality of life should be paramount and given greater attention than sovereignty and Canadian economic prosperity. Moreover, it should: "place at least as much emphasis on equitable trading arrangements internationally as on giving aid." ${ }^{301}$ To do so, it is argued by Oxfam,

\footnotetext{
${ }^{297}$ Ibid., 7.

${ }^{298}$ Rochlin, 92 . It should be noted that while there was an increase internationally, Canada only supplied three percent on Latin America's imports, well behind the American's thirty-seven percent share, and behind even Germany and Japan, 93.

${ }^{299}$ Ibid., 10.

${ }^{300}$ Rochlin, 96-7.

${ }^{301}$ Ibid., 15 .
} 
would eliminate the contradictions that were inherent in the White Paper. ${ }^{302}$ The changes proposed by Oxfam in response to the White Paper on foreign affairs are indicative of Oxfam's position and views of international development and Canadian international policy. Similarly, the policy recommendations made in the White paper reflect a changing perception of the value and necessity of a distinctive foreign policy and development. While there are certainly tensions between the two perspectives, together they demonstrate shifting notions of the world order and Canadian priorities.

The tensions between the White Paper and Oxfam Canada reveal that the Canadian government and NGOs often do not advance perfectly compatible international visions. However, NSAs and NGOs, while not representative of the Canadian federal government, participate in international reiations and are representatives of the state insomuch that they respond to state policies, and influence behaviours, and perceptions across society. ${ }^{303}$ Furthermore, they do not operate beyond state interests but rather parallel national motivations. They indicate that states are not exclusive agents of change, and, as Suri points out, NGOs have the capacity to "reframe the accepted applications of state power." 304 Therefore, while NGOs often assert an autonomous position, in fact they reflect national ideologies and have the capacity to influence national perspectives. ${ }^{305}$ For example, the constant assertion that Canada was distinct from the US in the White Paper is similarly reflected in Oxfam Canada's outlook. In a letter from Charles Skinner, the Field

\footnotetext{
${ }^{302}$ Ibid.

${ }^{303}$ Suri, "Non-Governmental Organizations," 224.

${ }^{304}$ Ibid., 224-6.

${ }^{305}$ Suri further states: "They influence how individuals define their allegiances. Most significantly, they socialize citizens to think of themselves as more than just members of a state. Identification with an international human rights community, for example, need not run against one's national patriotism," 226.
} 
Director for the Andes, to Bruna Smith, the Projects Officer, he states, in regards to a family planning project being implemented in Peru, that a series of conferences was not necessary and that it was important to ensure that projects did not have: "that lush American financed appearance." ${ }^{306}$ Oxfam Canada, while critical of the Canadian White Paper, also maintained that it was important to remain distinct from the Americans in order make progress on development projects. ${ }^{307}$

Some common assumptions and ideological outlooks between the Canadian government and Oxfam are evident through their attempts to appear non-American. Additional support indicating that Canada sought to move beyond American interests is demonstrated by the influx of Canadian aid to Latin America and Peru specifically. As discussed in the Introduction, Contreras demonstrates that the American government's distribution of aid to countries greatly depended upon the adherence of the recipient country to national frameworks that the US deemed acceptable. Canadian development attempted to move beyond contingencies such as those pursued by the United States. This is reflected in the White Paper through the assertion that: "the kind of social organization existing within a national state is the prerogative of that state. ${ }^{308}$ Indeed as Rochlin points out, Canada came to occupy a position in Latin America that was distinct from the US. ${ }^{309}$ That the social organization of a nation would not inhibit Canada from developing relations a state indicates that a country being governed by a Leftist military junta, such as that of

\footnotetext{
${ }^{306}$ Letter: Charles Skinner to Bruna Smith, 8 May, 1972, box 2, file 25: "South America: ApplicationsPeru 1971-1972," Oxfam Canada, Library and Archives of Canada, Ottawa, ON.

${ }^{307}$ Ibid.

${ }^{308}$ Department of External Affairs, "Latin America", 11.

${ }^{309}$ Rochlin, 33.
} 
Velasco Alvarado, would not affect development assistance, especially from nongovernmental sources.

Not only can Oxfam be viewed as an organization that reflected Canadian ideals and represented Canada internationally, but as Jennings argues, projects and interactions with governments, citizens, and partners were significantly influenced by what he terms the 'periphery'. ${ }^{310}$ The concept of peripheral influence further contradicts the premise that NGOs operate independently and outside of state interests. Specifically, Jennings argues that: "voluntary agencies willingly became surrogates of the state: acting for it and assisting it in its plans not only to develop the nation, but in the massive reorganisation of social and economic systems and structures, and political power, that accompanied that effort."3111 While Jennings focuses on Oxfam in Tanzania, a similar conclusion can be derived from the experiences in Latin America, and more specifically, in Peru. By combining Suri's and Jennings's theses, it becomes possible to comprehend how Oxfam was an actor that reflected the Canadian nation, but was also influenced by the country in which it operated. By being aware of the multiple levels of interaction the importance of NGOs and NSAs becomes apparent. Moreover, by the 1970s there was an influx of aid to Latin America, and Peru specifically.

In comparison to the rest of Latin America, Peru is an ideal country to analyze in terms of development for numerous reasons. To begin with, the extent of aid going to Peru from Canada was fairly substantial. A report published in 1972 by the Canadian Council for International Co-operation (CCIC) documents all NGO grants

\footnotetext{
${ }^{310}$ Jennings, "Surrogates of the State," 3.

${ }^{311}$ Ibid.
} 
given in the fiscal year $1970 .{ }^{312}$ Table 2, "Aid Given to Latin America by Country and Category, 1970", demonstrates the extent to which aid was distributed to each Latin American country by sector, namely agriculture, community development, education, health, relief and other general aid. It also provides information on the number of agencies, the number of projects, the monetary value of aid, and number of Canadians working on projects in each country. The data provided by the CCIC excludes national grants, and as such gives a glimpse of Canadian NGO initiatives globally. While the report is not entirely complete, and in some instances the aid documented extends into 1971, it does demonstrate the importance of Peru in comparison to the rest of Latin America. ${ }^{313}$ In almost all of the aid categories, Peru is the country with the most agencies, projects and money. Of all Latin American nations, Peru received the most aid in 1970 , totalling $\$ 1,055,838.00$. The next closest recipient was Brazil, which received $\$ 976,999.00 .{ }^{314}$ The extent of aid that Peru received from all Canadian NGOs makes it an important country to consider in the development context.

\footnotetext{
${ }^{312}$ Canadian Council for International Co-operation, Listing of International Development Projects and Activities Supported by Canadian Non-Governmental Organizations, Canadian Council for International Co-operation, (1972).

${ }^{313}$ Ibid., "The data in this publication pertains to the private, voluntary organizations in Canada. It does not include projects or programmes of the Canadian Government or the provincial governments, nor does it include any investment or development activities of Canadian corporations. The information was compiled during the summer and fall of 1971 and is based on the calendar year 1970 . Obviously it was difficult for many agencies to give us financial and personnel information corresponding exactly to a precise calendar year-and for many of them the information runs over into the fiscal year 1971 ... In any compilation of data... we must point out the fairly wide margin of error. Our statistics come from a wide variety of agencies many of whom find it difficult to do more than estimate their financial contribution to a project in a given time period, or to calculate the real value of material or personnel contributions. Similarly, while we think that we have covered almost all agencies, there are bound to be a few-particularly the smaller regional ones-that we haven't reached or didn't hear from," i-ii.

${ }^{314}$ Ibid., see Table 1.
} 
Table 2: Aid to Latin America by Country and Category, 1970

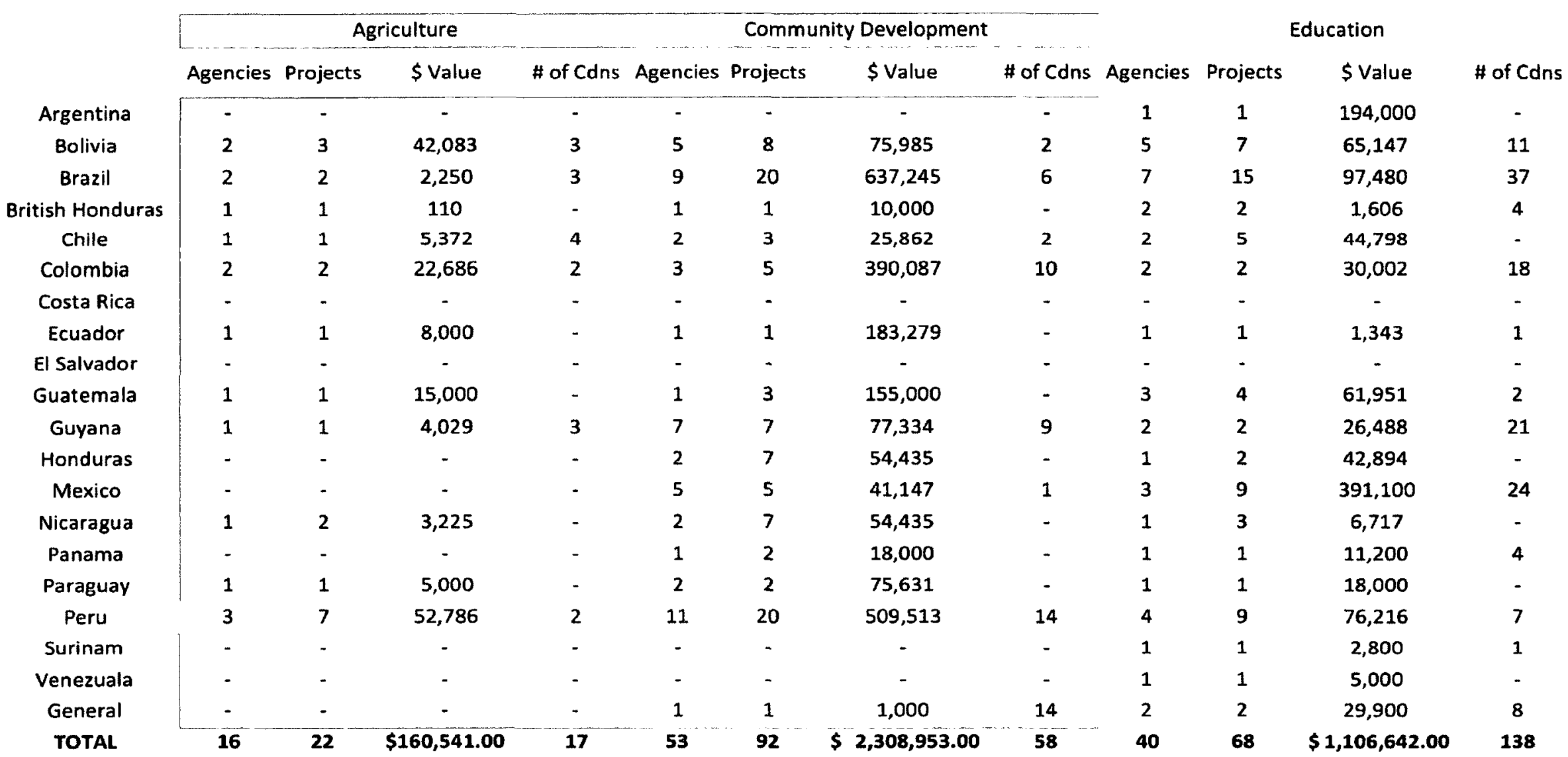

Source: Created using data from, Canadian Council for International Co-operation, Listing of International Development Projects and Activities Supported by Canadian Non-Governmental Organizations, Canadian Council for International Co-operation, (1972). Note: Agriculture includes farming, forestry, fisheries, and construction of agricultural buildings. Community Development includes community and social development, including cooperatives, technical assistance, tools, day care centers, child sponsorship, orphanages, social welfare programs, rural leadership training, youth services and construction of community centers. Education includes primary, secondary and post-secondary schools, school buildings and supplies, teacher support, scholarships and bursaries. Health includes medical services, support to hospitals and clinics, family planning, rehabilitation, and nutrition programs, and school feeding. Relief includes emergency disaster aid, relief food, clothing and other material, sponsorship of disaster victims. General includes anything that does not fit naturally into any of the above categories, such as multi-purpose projects, planning operations, and administrative. From CCIC listing, v-vi. 
Table 2: Aid to Latin America by Country and Category, 1970 (continued)

\begin{tabular}{|c|c|c|c|c|c|c|c|c|c|c|c|c|c|c|}
\hline & & & Health & & & & Relief & & & & General & & & \\
\hline & Agencles & Projects & \$ Value & $\#$ of Cdns & Agencies & Projects & \$ Value & \# of Cdns & Agencies & Projects & $\$$ Value & \# of Cons & & TOTAL AID \\
\hline Argentina & - & - & - & - & - & - & . & - & 1 & 1 & 8,690 & - & $\$$ & $202,690.00$ \\
\hline Bolivia & 6 & 7 & 43,713 & 5 & - & - & - & - & 1 & 1 & 1,230 & - & $\$$ & $228,158.00$ \\
\hline Brazll & 3 & 5 & 112,492 & - & 2 & 3 & 5,600 & - & 4 & 4 & 121,932 & 3 & $\$$ & $976,999.00$ \\
\hline British Honduras & 1 & 1 & 146 & - & - & - & * & - & 1 & 1 & 78,932 & & $\$$ & $90,794.00$ \\
\hline Chile & 1 & 1 & 10,744 & 8 & 1 & 1 & 5,400 & - & - & - & - & - & $\$$ & $92,176.00$ \\
\hline Colombia & 4 & 5 & 139,229 & - & 1 & 1 & 14,600 & - & 1 & 1 & 36,550 & - & $\$$ & $633,154.00$ \\
\hline Costa Rica & 2 & 2 & 31,873 & - & 1 & 1 & 9,000 & - & - & - & - & - & $\$$ & $40,873.00$ \\
\hline Ecuador & 1 & 1 & 16,555 & - & 1 & 1 & 10,300 & - & 1 & 1 & 18,100 & - & $\$$ & $237,577.00$ \\
\hline El Salvador & 1 & 1 & 5,000 & - & - & - & - & - & - & - & - & - & $\$$ & $5,000.00$ \\
\hline Guatemala & 1 & 1 & 10,000 & - & 1 & 1 & 11,500 & - & - & - & - & . & $\$$ & $253,451.00$ \\
\hline Guyana & 2 & 2 & 4,104 & 3 & 1 & 1 & 7,200 & - & - & - & - & - & $\$$ & $119,155.00$ \\
\hline Honduras & 1 & 1 & 21,740 & - & - & - & - & - & - & - & - & - & $\$$ & $119,069.00$ \\
\hline Mexico & 2 & 4 & 7,300 & 1 & - & - & - & - & - & - & - & - & $\$$ & $439,547.00$ \\
\hline Nicaragua & 1 & 1 & 600 & - & 1 & 1 & 9,500 & - & - & - & . & - & $\$$ & $74,477.00$ \\
\hline Panama & - & - & - & - & . & - & - & - & - & - & - & - & $\$$ & $29,200.00$ \\
\hline Paraguay & - & - & - & - & - & - & - & - & - & - & - & - & $\$$ & $98,631.00$ \\
\hline Peru & 6 & 12 & 108,128 & 14 & 6 & 9 & 190,945 & - & 5 & 5 & 118,250 & 2 & $\$$ & $1,055,838,00$ \\
\hline Surinam & - & - & - & - & - & - & - & - & - & - & - & - & $\$$ & $2,800.00$ \\
\hline Venezuala & - & - & - & - & - & - & - & - & - & - & $\cdot$ & - & $\$$ & $5,000.00$ \\
\hline General & - & - & - & - & - & - & - & - & - & - & - & - & $\$$ & $30,900.00$ \\
\hline TOTAL & 32 & 44 & $\$ 511,624.00$ & 31 & 15 & 19 & $\$ 264,045.00$ & 0 & 14 & 14 & $\$ 383,684.00$ & 5 & $\$$ & $4,735,489.00$ \\
\hline
\end{tabular}

Source: Created using data from, Canadian Council for International Co-operation, Listing of International Development Projects and Activities Supported by Canadian Non-Governmental Organizations, Canadian Council for International Co-operation, (1972). Note: Agriculture includes farming, forestry, fisheries, and construction of agricultural buildings. Community Development includes community and social development, including cooperatives, technical assistance, tools, day care centers, child sponsorship, orphanages, social welfare programs, rural leadership training, youth services and construction of community centers. Education includes primary, secondary and post-secondary schools, school buildings and supplies, teacher support, scholarships and bursaries. Health includes medical services, support to hospitals and clinics, family planning, rehabilitation, and nutrition programs, and school feeding. Relief includes emergency disaster aid, relief food, clothing and other material, sponsorship of disaster victims. General includes anything that does not fit naturally into any of the above categories, such as multipurpose projects, planning operations, and administrative. From CCIC listing, v-vi. 
While a comprehensive review of all development agencies in Peru throughout the 1970s is well beyond the scope of this thesis, Oxfam Canada did undertake numerous projects in Peru that are worth considering. Between 1970 and 1972, Oxfam Canada made grants to the Compagnie Internationale de Développement Rural (CIDR) for the support and expansion of coffee cooperatives. Oxfam Canada and CIDR officials viewed the migrations of Quechua and Aymara men, who often migrated at the time of the coffee harvest to aid in processing the crop, as an area that required reform. In 1970, a report from Oxfam Canada regarding CIDR cooperatives recorded that: "the project is helping the development of a newly colonized area which can offer the people of the bleak and infertile Andean plateau an alternative to migration to city slums." ${ }^{317}$ The redirection of people is reiterated throughout the various reports and letters concerning the CIDR coffee cooperatives, which makes it clear that these migrants were one of the intended beneficiaries of the initiatives undertaken by these institutions.

The people that the project being implemented by Oxfam and CIDR aimed to assist were also part of the national colonization project that Velasco Alvarado was implementing as described in Chapter One. While Oxfam did not maintain a socialist organizational mandate, they were very much a part of the Peruvian socialist nexus, particularly as their projects mirrored those being implemented by Velasco Alvarado, a leftist government that was undertaking socialist reforms. While the projects conducted by Oxfam and various other NGOs were not intended as socialist

\footnotetext{
${ }^{317}$ Letter: Charles Skinner to David Carter, 20 May, 1970, box 49, file 24, "Peru-CIDR Coffee CoopHelp to support its work- correspondence, reports and other related material 1970-1972," Oxfam Canada, Library and Archives of Canada, Ottawa, ON.
} 
experiments, they were taking part within the ambit of the national cooperative experiment, which was explicitly a socialist venture.

The Peruvian state, under Velasco Alvarado, initiated the transition from haciendas to cooperatives in 1968 . This form of agricultural organization was quickly implemented by the CIDR, which received sponsorships from Oxfam Canada. Surprisingly, Oxfam's documents make no mention of the agrarian reform programs Velasco Alvarado had implemented. Rather, Pierre Thiran, the project manager for CIDR in Peru, asserts that the spread and apparent success of the cooperative movement was the result of international aid from organizations such as CIDR and Oxfam. The exclusion of this information is revealing of CIDR and/or Oxfam's self view of being autonomous and beyond state influence. While it is highly likely that Thiran would have been aware of these reforms, and while there is no explicit link made between the CIDR cooperatives and the national cooperative movement, the rural reforms and the cooperative movement that Velasco Alvarado implemented were mirrored in NGO projects in Peru at this time ${ }^{318}$ While the cooperative movement is the most obvious influence from the periphery, several other influences are also evident. These can be seen in the use of Peruvian national institutions, such as the Peruvian Rural Development Bank, and SINAMOS. The use of Peruvian state initiatives and institutions reflect influence within Oxfam and CIDR by the 'periphery.'

In a "Progress Report" from 1969, Thiran makes explicit the use of the Peruvian Rural Development Bank. On page three of the report, Thiran writes that

\footnotetext{
${ }^{318}$ Another NGO in Peru at this time that set-up coffee cooperatives was Equal Exchange, who still currently operates and funds cooperatives.
} 
credit for three cooperatives was coming from the Rural Development Bank. These cooperatives received more than 14 million Peruvian Soles. After the sale of the coffee the bank would be guaranteed to recover the initial investment plus 10 percent in interest, with an ensured price of 750 soles per sack of coffee. The remaining profit would go to the co-operator, although costs would be deducted and each co-operator was required to invest a set amount into an investment fund. ${ }^{319}$ Based on the return of 10 percent interest, the bank was "guaranteed" to make a return of 1.4 million soles. The series of costs mentioned above include transport costs ( $20-25$ soles), fire insurance ( 1.75 soles/ quintal of $100 \mathrm{lbs})$, and a voluntary investment toward the coffee factory of 15 soles per quintal, and finally 10 soles per quintal for handling costs. ${ }^{320}$ There is no indication as to the average quintals produced; therefore, it is difficult to calculate the total costs taken out of the cooperative's profit. Additionally, the salaries listed in the expenditure report only account for the secretary at the central cooperative, three administrative staff, one cooperative secretary, and one receptionist. ${ }^{321}$ The salaries were not coming out of the profits from the sale of coffee, but rather from international support. ${ }^{322}$ While it would appear that the payment of salaries by development organizations would minimize the expenditure of profits, in fact, it brings into question the ability of the cooperative to support itself. Based on the loans acquired from the bank, it seems then, that the individual farmer was not directly receiving the profit. Rather, as the expenditure reports indicate, much of the

\footnotetext{
${ }^{319}$ First Progress Report, 3.

${ }^{320}$ Ibid.

${ }^{321}$ Breakdown of Expenditure, September 11, 1969, box 49, file 25 "Peru - CIDR Coffee co-op - Help to support its work -Correspondence, reports and other related material (3 of 4), 1970-1972" Oxfam Canada, Library and Archives of Canada, Ottawa, ON: 4.

${ }^{322}$ Ibid.
} 
income was reinvested into the cooperative structure and went to paying administrative staff.

There is no mention of the actual or projected income of the farmers anywhere in the report. Thiran writes that, as a result of the cooperatives: "the head of the family will be receiving two and a half times more money." ${ }^{323}$ However, nowhere in the report is it revealed how this figure is calculated. The lack of information regarding the actual amount that the individual farmer made makes it difficult to assess the success of the CIDR cooperatives beyond the general statements that Thiran makes. However, it is widely believed that cooperatives in Latin America have generally been unsuccessful in alleviating poverty as, contrary to expectations, the initiative was most unlikely to provide a broad, equitable distribution of the benefits of co-operation among the rural population or to increase rural political participation. ${ }^{324}$ The missing information further leads to questions about the Rural Development Bank, as it appears that it was making a greater (and guaranteed) profit, quite different from what the individual farmer was getting. Through the use of state run institutions, such as the Rural Development Bank, CIDR and Oxfam Canada reinforced national institutions.

Secondly, while Oxfam was highly critical of SINAMOS, they did deem it necessary to direct aid through the organization. For example, in a discussion about what projects should be undertaken in Peru, Bruna Smith writes that community development projects should: "be a priority because it fall [sic] within an area to

\footnotetext{
${ }^{323}$ First Progress Report, 1-2.

${ }^{324}$ Tanya Korovkin, "Politics of Agricultural Co-Operativism: Peru, 1969-1983." (University of British Columbia Press: Vancouver, B.C., 1990): 5, accessed January 29, 2011, from: http://www.questia.com/PM.qst?a=o\&d=29330151\#.
} 
which the Government of Peru is giving increasing emphasis; namely the protection and development of the Indians." 325 The explicit intention to conduct projects that aligned with Peruvian governmental reforms indicates that there was at least some degree of harmony between Oxfam's projects and the Leftist Peruvian government reforms. Significantly, she further argues that to ensure that the project would be successful, it would be important to integrate the project with SINAMOS and other existing government programmes. ${ }^{326}$ The perception that Oxfam thought that it was necessary to implement projects that coincided with Peruvian state reforms demonstrates that they willingly worked with a government that was Leftist and encouraged this national framework. The programmes and initiatives that Oxfam undertook in Peru in the 1970s further indicate influence from the periphery. Oxfam, for example, did not seek to focus on health or water projects at this time, but rather on community and agricultural development, which was the same focus of the Peruvian government.

The goals and observations that are expressed in the progress reports and various letters from the CIDR to Oxfam Canada, and within Oxfam, are revealing of how NGOs were influenced by what Jennings refers to as the 'periphery.' In addition, and also more indicative of this argument, is the fact that the aim for many NGOs was not to undermine state hegemony, but rather to support it, and to encourage regimes to accept their responsibilities where they were seen to be failing. ${ }^{327}$ Moreover, this influence and adherence to state initiatives further places Canadian NGOs within the

\footnotetext{
${ }^{325}$ Letter: Bruna Smith to Michael McCormick, 26 November, 1972, box 2, file 25: "South America: Applications- Peru 1971-1972," Oxfam Canada, Library and Archives of Canada, Ottawa, ON. 326 Ibid., 3.

${ }^{327}$ Jennings, "Surrogates of the State," 19.
} 
socialist nexus of Peru. The cooperatives that Velasco Alvarado promoted were socialist organizations, which required a reform of economic, social, and political structures. This reorientation was mirrored by NGOs like CIDR and Oxfam Canada. It is also interesting to note that, in the First Progress Report, CIDR and Oxfam appear to assume the credit for spreading the cooperatives, thereby reinforcing the notion that NGOs perceived their initiatives to be autonomous from state operations. However, a closer reading reveals that Oxfam and CIDR were in fact influenced by the aims of the Peruvian state. Their influence from the periphery is illustrated by Oxfam and CIDR's utilization of state institutions, such as the Rural Development Bank and SINAMOS.

Canadian attempts to redefine foreign policy, as is reflected in Foreign Policy for Canadians and the "Third Option", reveal that by the 1970s Canada was pursuing a policy that attempted to move beyond the traditional Cold War rhetoric and was willing to develop diplomatic and trade relations with states that were influenced by communist and socialist ideals. These choices and actions, and the activities of Oxfam, place Canada within the socialist milieu of countries such as Peru. In addition, Canadian labour unions were prominent actors in the international petition to have Hugo Blanco's death sentence reversed. The letters and correspondence between these unions and their subsequent appeal to the Peruvian government are revealing of Canadian attitudes toward the social inequalities that Blanco was agitating against and the Canadian support of socialist activists in Peru.

Numerous labour unions and universities across Canada appealed for the release of Hugo Blanco. Considering that there are a large number of documents that 
are still restricted by law, ${ }^{328}$ the following discussion will unfortunately be rather cursory. Some documents, however, such as the proceedings from the conference "Free Hugo Blanco," provide insight into the actions taken to appeal Blanco's sentence. Further, in Blanco's book, Land or Death, his letter to those who petitioned for his release illustrates the universality of the movement to free Blanco and connects these international actors to the Peruvian socialist movement. These and other available documents highlight the involvement of Canadian institutions in the socialist nexus of Peru.

Petitions from around the world flooded into Peru to push for the reversal of the death sentence that Blanco received after being captured in 1963 for leading a peasant rebellion (as discussed in Chapter Two). Prominent intellectuals such as JeanPaul Sartre and Simone de Beauvoir from France, forty-three members of Belgium's House of Representatives, numerous British Labour MPs, historians such as Isaac Deutscher, architects such as Oscar Niemeyer, and numerous international organizations such as Amnesty International and the International League for Human Rights, to name a few, all participated in the effort to advocate for Blanco's release. ${ }^{329}$ Many Canadian individuals and organizations participated in the movement as well. Labour unions, such as Quebec Labour Union, ${ }^{330}$ and university professors such as Crawford Brough Macpherson, an influential political scientist

\footnotetext{
${ }^{328}$ These are located in the "Canadian Trotskyist Movement" collection at Library and Archives Canada, Ottawa ON. There is a wide selection of documents in this collection pertaining to Hugo Blanco and the Canadian effort to appeal his imprisonment and death sentence. This would prove an interesting study in the future as these documents become available.

${ }^{329}$ André Gunder Frank \& Kenneth Golby, "Free Hugo Blanco," (conference proceedings, Toronto, ON: University of Toronto, January 27, 1969): 3-4.

${ }^{330}$ This union is used as an example as it appears that it was this union that initiated discussion between the various unions. There was correspondence between multiple labour unions across Canada. To review these letters see: International Affairs Department, "Blanco, Hugo (Peru). Imprisonment. Pamphlets, correspondence," Library and Archives of Canada, Ottawa, ON.
} 
from the political economy department of the University of Toronto, as well as Kenneth McNaught from the history department, of the University of Toronto, are but two examples of prominent Canadians who advocated for Blanco's release.

André Gunder Frank (born in Berlin and educated in Chicago), an economic historian and sociologist was influential in the movement to free Blanco. In the speech that he gave at the University of Toronto in 1969 , he poses the question to the audience: "what is to be done?"331 This question goes beyond attempting to secure Blanco's freedom, and encompasses the larger issues in Cuzco and more generally all revolutionary movements in Latin America- movements like Blanco's that sought to change the unequal land system. Frank explicitly connects the revolutionary struggles in Latin America to Canada stating that: "What is important [...] is the connection between revolutionary activity there and revolutionary and progressive political activity here." 332 Moreover, he attempts to demonstrate that the persecution of rebels, such as Hugo Blanco, was connected to the global imperialist system, which in turn was reflected by the Peruvian bourgeoisie. The imperialist system and the bourgeoisie exploited the peasantry in the interest of maximizing profits. ${ }^{333}$ This exploitation, he argues, would continue under the maintenance of the capitalist system and would inevitably create a perpetual pattern of revolutionary struggles. To overcome such exploitation, Gunder Frank concludes by arguing that the Canadian people first needed to overturn the imperialist system at home. He argues: "the more we can attack this system here, the more we will be helping the peasants led by Hugo Blanco[...] those who will necessarily follow him, and who will in his words gain

\footnotetext{
${ }^{331}$ Ibid., 10.

${ }^{332}$ Ibid.

${ }^{333}$ Ibid., 13.
} 
'Tierra o Muerte. ${ }^{, 334}$ Gunder Frank attempts to explicitly link the Peruvian cause, and indeed the global revolutionary struggle, to the local context of Canada. The language that he employs is socialist and the necessity to struggle against the imperialist system is radical. The explicit link to the international level, and the subsequent action taken to free Blanco, indicates that this type of thinking transcended national borders, which places NSAs in the international realm. By considering these types of actors, it is possible to transcend the actions of nation states, and probe the extent of socialist activity at the international level, even from states traditionally deemed to be anticommunist.

Gunder Frank's insistence on creating a national movement that would subvert the imperialist order and have global effects is similarly reflected in a letter Blanco wrote to the global associations and individuals that petitioned for his release. In Land or Death, Blanco includes numerous documents and letters that pertain to the movement he led in La Convención Valley beginning in 1961. In 1967 Blanco wrote a letter to: "Those Who Protested the Death Sentence." ${ }^{335}$ He states: "Your voice of solidarity resounds throughout the world... People of all languages, your protest has risen in a chorus of the universal language of human solidarity. ${ }^{.336}$ The language that Frank and Blanco employ moves beyond nation states and attests to a global connection and a wider socialist nexus. Blanco further argues that, even if the international effort to free him was unsuccessful, the actors petitioning on his behalf

\footnotetext{
${ }^{334}$ Ibid., 16.

${ }^{335}$ Blanco, Land or Death, 100-101.

${ }^{336}$ Ibid., 100.
} 
led by example and strengthened international solidarity. ${ }^{337}$ This evocation of a global solidarity attests to the connections of various nations to the socialist nexus that was manifested in Peru throughout the 1960s.

Blanco was freed in December of 1970 under an amnesty law passed by Velasco Alvarado. ${ }^{338}$ While the international attempt to free Blanco did not necessarily lead to his freedom, the participation of international actors in the movement highlights the presence of Canadian and numerous other countries in the socialist milieu of Peru. Further evidence of Canadian participation in the Peruvian socialist nexus was the influx of Canadian development aid that conformed to the Peruvian national initiatives that were implemented by Velasco Alvarado. The ability of NGOs to undertake such projects was significantly reinforced by changing perceptions of development aid. As has been discussed, Canada maintained a stance that development projects and aid packages should be pursued despite the social organization of states. The increase in official development aid occurred as nongovernmental aid increased as well. The actions of NGOs and NSAs reveal that Canada was part of the Peruvian socialist nexus in that they participated, both explicitly and implicitly, in projects that were inherently socialist in nature. While Oxfam did not maintain a socialist position or propagate socialist ideals in Canada, the projects that they undertook in Peru conformed to the socialist experiment that Velasco Alverado implemented. Conversely, the various unions and NSAs that petitioned for Blanco's release unequivocally maintained a socialist position and

\footnotetext{
${ }^{337}$ Ibid., 101. Blanco goes on to assert that this would further extend to: "the victims of repression in Latin America, and in all the countries fighting to liberate themselves; to the people who fight to maintain their independence, as in Cuba. Solidarity with the Vietnamese people, to whom the human race owes so much, will increase beyond measure."

${ }^{338}$ Hugo Blanco, "Peru: veteran guerrilla fighter."
} 
gathered to attempt to free a socialist prisoner. Moreover, in petitioning for his release, they called for a wider application of socialist ideals to be applied in Canada. While these actions were neither undertaken nor endorsed by the Canadian government, they are reflective of Canada's international presence. 


\section{Conclusion}

The placement of Canadian actors and organizations in the socialist nexus of Peru is an important contribution to Cold War studies as it demonstrates the complexity of international relations and significantly moves beyond the rhetoric of dividing the world of inter-state relations into two blocs- communist and anticommunist. While there certainly were countries that clearly identified with either bloc, it is necessary to identify and examine the places where these categorizations cannot so easily be applied. Cold War studies that aim to identify and delineate deviation from these two blocs expose the superficial nature of these categorizations and reveal the complexity of international relations at this time, moving beyond the realist assumptions of a bipolar worid.

To fully capture the extent of Canadian involvement in the socialist nexus, it was first necessary to outline and specify the Peruvian context in which Canada was active. Tracing the growth of the Left in Peru demonstrates that socialist movements were not linear or cohesive, as their actors were often at odds ideologically. The inability of the Left to unite under a common goal significantly inhibited them from launching successful revolutions or gaining political power. While there were limitations on the power that the Left was able to harness, the presence of socialist actors and their ability to participate actively in elections placed pressure on governments. The issue of legitimacy further resulted in some parties, such as the APRA, moving from the far Left to a more conservative position. This occurred as leaders of parties sought to obtain power by creating coalitions. However, the transition from the left resulted in a political vacuum, out of which new left parties, 
such as the AP, were created. While there were brief moments where there was little representation of far Left parties, these were not usual and the Left maintained a prominent foothold in the Peruvian political landscape.

The identification of Canadian actors within the socialist landscape of Peru is significant since few scholars have considered the extent to which Canada participated in socialist activities abroad, particularly from a nongovernmental position. In examining Canadian/Peruvian relations during the Cold War and the projects that NGOs, such as Oxfam, conducted in Peru, as well as the advocacy of Canadian unions for the release of Hugo Blanco, it is demonstrated that actors from Western aligned countries participated in socialist activities, even on the international stage. While the review of Canadian NGO projects and union activities internationally does not provide a comprehensive picture of Canadian foreign relations during the Cold War, it nevertheless begins to illuminate the necessity of revisiting traditional Cold War understandings and analyzing actors other than nation states. The analysis of NGOs and NSAs is a feasible method for examining the Canadian presence in international relations as the federal government is not the only international actor in the global context. Further, as Suri points out, while NGOs and NSAs maintain that they operate outside of state authority, in fact they reflect and incorporate national ideologies into their initiatives. Future studies that examine government documents, when they become available, as well as other NGOs and their projects, will provide deeper insight into the Canadian position at this time.

A broader awareness of how Canada positions itself in the international realm is important as global connections between states continue to proliferate. Further, it is 
important to consider the extent that NGOs and NSAs represent Canada internationally. While these types of organizations are not necessarily reflective of official state initiatives, there are a growing number of these types of organizations and they have become legitimate actors on the international stage. Understanding how Canada has conducted relations outside of the government in the past is important in framing how we conduct international relations now and in the future. Moreover, gaining an understanding of how NGOs and NSAs conform and contribute to state initiatives and being conscious of how multiple state and non-state actors disseminate and/or reflect ideologies beyond their own national ideologies will contribute to a better understanding of interstate dynamics.

As this thesis has demonstrated, Canadian NGOs and other NSAs participated in a variety of activities internationally that did not necessarily conform to the perceived national position of a Western ally. This apparent contradiction reveals that there were, and are, a multiplicity of actors that operate on the international stage. Therefore, asserting that a nation maintains a single ideological position becomes problematic as ideologies do not exist in isolation, but rather are contested and in constant flux. This is similarly reflected in the Peruvian context as various and multiple actors that identified as being socialist contested and negotiated what being socialist meant and how that ideology should be applied. Defining a nation as communist or anticommunist has little value in understanding inter-state relations as these labels fail to capture the plurality of voices competing and negotiating for state power. By examining the process and context in which these negotiations occur, 
superficial categorizations are rendered obsolete and meaningless as diverse and varied ideological persuasions are made apparent.

Understanding how movements, such as socialist ones, form and are perpetuated within a national discourse reveals not only a multiplicity of voices but also makes clear that numerous attempts have been made to alleviate the inequitable land holding patterns in Peru. In my recent trip to Peru to interview Hugo Blanco, it became evident that many of the same issues that he had agitated against remained. The interview was cancelled at the last minute as Blanco was called to the North to negotiate between mining companies and the local population, which is mainly indigenous. Blanco, in a recent article, states that: "Before, in my time, we struggled for the land, therefore our cry was 'Land or Death'; but now the struggle is for water. ${ }^{1339}$ Increasingly across the Andes environmental debates and concerns are being brought into focus.

Rights and access to natural resources are being contested as local populations are excluded and affected by the actions being taken by both national and foreign companies. In the case of Cajamarca, in the North of Peru where Blanco and other social activists are challenging mining operations, numerous violent clashes have occurred, and yet, multi-billion-dollar water-intensive gold mining has continued. ${ }^{340}$ These debates are increasingly being framed in environmental terms and NGOs and NSAs from around the world are participating within the movement. Understanding the form of movements from the 1960s, in addition to how interaction between states,

339 "Cajamarca quiere agua, no oro," Público, July $8^{\text {th }}, 2012$, accessed July 27,2012 from: http://www.publico.es/internacional/439388/cajamarca-quiere-agua-no-oro My translation. ${ }^{340}$ Mattia Cabizta, "Peru Mine Disputes mar President Humala's First Year," BBC News: Latin America and Caribbean, July $27^{\text {th }}, 2012$, accessed July 27, 2012 from:

http://www.bbc.co.uk/news/world-latin-america-18980109 
political actors, and NGOs both facilitated and limited rights and access to natural resources, such as land, is helpful to understanding and resolving the current situation. The past movements allow for important lessons to be applied to the current situation. Many of the same issues that led to Blanco initiating a movement in the 1960s are still relevant to the social and political landscape of Peru, and much of the Andes, as disputes continue to heighten over access and rights to natural resources such as land and/or water. Future studies should explore the linkages between former social movements in the Andes to contemporary issues, and consider the historical trajectory of rights and access to natural resources. Such a study would further trace international connections and contribute to a broader understanding of the contemporary issues that Peru currently faces.

As citizens, political entities, NGOs, and NSAs engage in debates and issues such as those that are currently occurring in Peru, it is important to consider the historical context out of which these controversies have arisen. There is little to no literature on Canadian/Peruvian relations. Furthermore, NGOs and NSAs have also received little scholarly attention. Given that NGOs were important actors in the Cold War context, and continue to be integral actors on the world stage, more attention needs to be given to their activities in a historical context. This analysis has demonstrated that, by exploring inter-state relations through the activities of NGOs and NSAs, a more nuanced approach to Cold War studies is possible. This type of survey reveals complex inter-state relations and a multiplicity of international actors that, while outside of the official state apparatus, both influenced and were influenced by state initiatives. This type of investigation further demonstrates that movements 
that have been traditionally deemed as local, such as the one that Blanco initiated, extend beyond borders and connect states in ways that are obscured by analyses that center on state actors as the only agents of inter-state relations. 
List of Abbreviations

AP-Acción Popular (Popular Action Party)

APRA- Alianza Popular Revolucionaria Americana (American Popular

Revolutionary Alliance)

APRA Rebelde-Rebel American Popular Revolutionary Alliance

CCIC- Canadian Council for International Co-operation

CIDA- Canadian International Development Agency

CIDR- Compagnie Internationale de Développement Rural (International Rural Development Company)

CP- Communist Party of Peru

EAO- External Aid Office

ELN- Ejército de Liberación Nacional (National Liberation Army)

FLN- National Liberation Front

FIR- Frente de la Izquierda Revolucionaria (Revolutionary Left Front)

FPCC- Federación Provincial de Campesinos de la Convención y Lares (Provincial Peasant Federation of La Convención and Lares)

FTC- Federación de Trabajadores del Cuzco (Cuzco Federation of Workers)

GCTP- Confederación General de Trabajadores del Perú (General Confederation of Peruvian Workers)

ICAD- Comité Interamericano de Desarrollo Agrícola (The Interamerican Committee for Agricultural Development)

INP- Instituto Nacional de Planificación (National Planning Institute)

IPC- International Petroleum Company

IRAC- Instituto de Reforma Agraria y Colonización (Institute of Agrarian Reform and Colonization)

MDP - Movimiento Democrático Peruano (Peruvian Democratic Movement) 
MIR-Movimiento de Izquierda Revolucionaria (Movement of the Revolutionary Left)

NGO- Non-governmental organization

NSA- Non-state actor

OAS- Organization of American States

PIP- Peruvian Intelligence Police

PM- Prime Minister

POR-Partido Obrero Revolucionario (Revolutionary Workers Party)

SINAMOS- el Sistema Nacional de Apoyo a la Mobilización Social (the National System for the Support of Social Mobilization)

UNO- Unión Nacional Odriísta (National Odriist Union) 


\section{Appendix I: Final Election Results Released by the National Election Jury, July $17^{\text {th }} 1962$.}

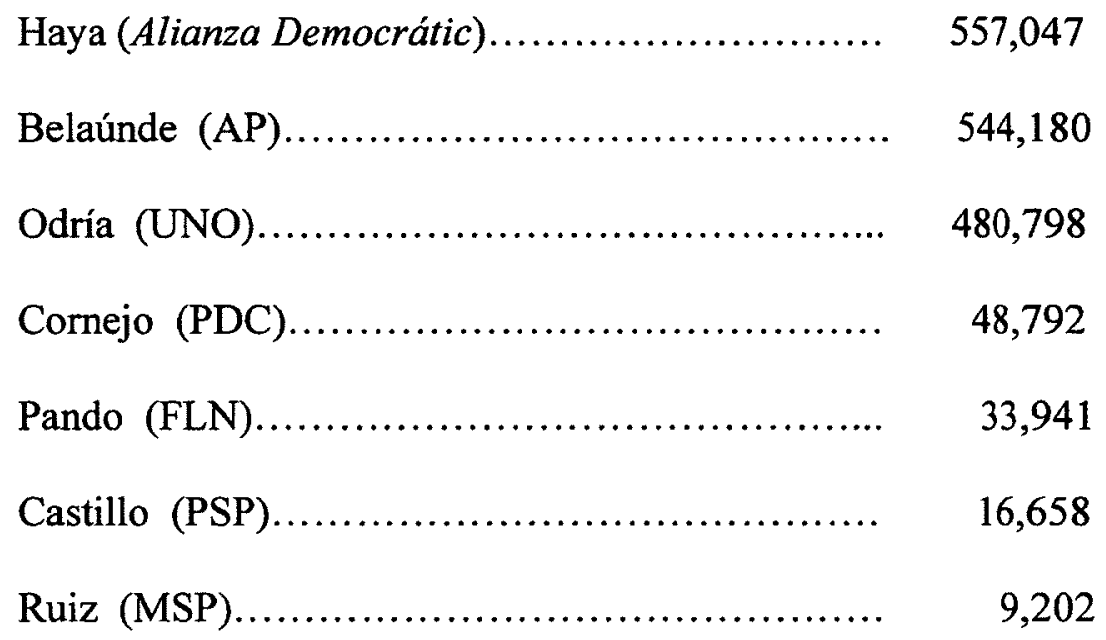

Source: Arnold Payne, The Peruvian Coup D'Etat of 1962: The Overthrow of Manuel Prado, Political Studies Series, no.5 (Washington, D.C.: Institute for the Comparative Study of Political Systems, 1968): 43. 


\section{Bibliography}

Archival

International Affairs Department. "Blanco, Hugo (Peru). Imprisonment. Pamphlets, correspondence." Library and Archives Canada. Ottawa, ON

Oxfam Canada fonds. Library and Archives Canada. Ottawa, ON. Prepared in 2003 by Arthur Grenke, of the Social and Cultural Archives.

Frank, G. Andre \& Golby, Kenneth. "Free Hugo Blanco." Conference proceedings, Toronto, ON: University of Toronto, (January 27, 1969). Library and Archives Canada, Ottawa, ON. Part of: International Affairs Department. "Blanco, Hugo (Peru). Imprisonment. Pamphlets, correspondence." Library and Archives Canada. Ottawa, ON

\section{$\underline{\text { Primary }}$}

Alvarado Velasco, Juan. "Mensaje a la Nación con motivo de la promulgación de la Ley de la Reforma Agraria." From Juan Alvarado Velasco, Voz de la Revolución: Discursos del Presidente de la República, General de División Juan Velasco Alvarado, 1968-1970. Issued October 9, 1968. Transcribed by Juan Fajardo (2012). Accessed June 18, 2012 from: http://www.marxists.org/espanol/velasco/1969/junio/24.htm.

Béjar, Héctor. Peru 1965: Notes on a Guerilla Experience. Translated by William Rose. New York, N.Y.: Monthly Press Review, 1970).

Blanco, Hugo. "An Interview with Hugo Blanco Glados." Interview by Alan Ramón Ward. International Journal of Postcolonial Studies, 13.4 (2011): 651-663. http://dx.doi.org/10.1080/1369801X.2011.628153

Blanco, Hugo. Land or Death: The Peasant Struggle in Peru. Translated by Naomi Allen. New York, NY: Pathfinder Press, 1972.

Blanco, Hugo. "Peru: veteran guerilla fighter Hugo Blanco speaks on Amazon struggle." Interview by Bill Weinberg. War 4 Report. August 28, 2009, Arequipa, Peru. Accessed July 13, 2012 from: http://www.chiapassupport.org/Blanco-interview-10-09.pdf

Blanco, Hugo. "The Epic Struggle Indigenous Andean-Amazonian Culture." Translated by Phil Cournoyer. International Viewpoint. IV Online Magazine, IV392, September 2007. Accessed May $15^{\text {th }}, 2012$ from: http://www.internationalviewpoint.org/spip.php?article1310 
Canada. Department of External Affairs. "Canada/U.S. Relations: Options for the Future." Special issue, International Perspectives, by Mitchell Sharp. Ottawa, ON: Secretary of State for External Affairs, 1972.

Canada. Department of External Affairs. Foreign Policy for Canadians by Mitchell Sharp. Ottawa, ON: Queens Printer,1970.

Griffis, Donald I. "PERU'S AUSTERITY PAYING DIVIDEND: Improved Financial Position Is Credited to Premier," Special to The New York Times January 11, 1961. Accessed June 25, 2012 from: ProQuest Historical Newspapers: The New York Times (1851-2008).

Mariátegui Carlos, José. Seven Interpretive Essays on Peruvian Reality. Translated by Marjory Urquidi. Austin Texas: University of Texas Press, 1988.

New York Times. "The Peruvian Peasant." November 15, 1962. Accessed June 25, 2012 from: ProQuest Historical Newspapers: The New York Times (18512008).

Pearson, Lester B.; Boyle, Edward; Campos, Roberto; Dillon, Douglas C.; Guth, Wilfred; Lewis, Arthur W.; Marjolin, Robert E.; Okita; Saburo. Partners in Development: Report of the Commission on International Development. New York, NY: Praeger Publishers, 1969.

$\underline{\text { Secondary }}$

Agnus, Ian. "How to make an Ecosocialist Revolution." Paper prepared for a Conference Climate Change, Social Change, Melbourne Australia, Victorian Trades Hall, October 2011. Accessed May 15, 2012 from: http://climateandcapitalism.com/201 1/10/07/how-to-make-an-ecosocialistrevolution/

Alexander, Robert Jackson. "Peruvian Trotskyism." In International Trotskyism, 1929-1985: A Documented Analysis of the Movement. Durham, NC: Duke University Press, 1991

Alsina, Andrés. "Hector Bejar's long road." Social Watch, (n.d.). Accessed June 10, 2012 from: http://old.socialwatch.org/en/acercaDe/prensa7.htm.

Angotti, Thomas. "The Contributions of José Carlos Mariátegui to Revolutionary Theory." Latin American Perspectives 49.14 (1989): 33-57. http://www.jstor.org/stable/2633646 .

Béjar, Héctor. Personal webpage (n.d.). Accessed June 10, 2012 from: http://www.hectorbejar.com/ 
Bernard, Jean Pierre; Cerqueira, Silas; Gilhodès, Pierre; Graillot, Hélène; Manigat, Leslie F.; Neira, Hugo. Guide to the Political Parties of South America. Translated by Michael Perl. Baltimore, MA: Penguin Books 1973.

Bethell, Leslie ed. The Cambridge History of Latin America: Latin America since 1930. Cambridge: The University of Cambridge Press, 1991.

Black, Maggie. A Cause for Our Times Oxfam the First 50 Years. Toronto, ON: Oxford University Press, 1992.

Brass, Tom. "How agrarian cooperatives fail: Lessons from 1970s Peru." Journal of Peasant Studies 34.2 (2007): 240-287. doi 10.1080/03066150701516690

Brass, Tom. "Trotskyism, Hugo Blanco and the ideology of a Peruvian peasant movement." Journal of Peasant Studies 16.2 (1989):173-197. http://dx.doi.org/10.1080/03066158908438389

Brown, Michael F. \& Fernández, Eduardo. War of Shadows: The Struggle for Utopia in The Peruvian Amazon. Los Angeles, CA: University of California Press, 1991.

Bothwell, Robert. The Big Chill: Canada and the Cold War. Toronto, ON: Irwin Publishing, 1998.

Bothwell, Robert. Pearson: His Life and World. Toronto ON: McGraw-Hill Ryerson Limited, 1978.

Cabizta, Mattia. "Peru Mine Disputes mar President Humala's First Year." BBC News: Latin America and Caribbean, July $27^{\text {th }}, 2012$. Accessed July 27, 2012 from: http://www.bbc.co.uk/news/world-latin-america-18980109

Campbell, Leon G. "The Historiography of the Peruvian Guerrilla Movement, 19601965." Latin American Research Review 8.1 (1973): 45-70. http://www.jstor.org/stable/2502695

Canada. International Development Research Centre. "About Us." Accessed July 28, 2012 from: http://www.idrc.ca/EN/AboutUs/Pages/default.aspx

Canadian Council for International Co-operation. Listing of International Development Projects and Activities Supported by Canadian NonGovernmental Organizations. Canadian Council for International Cooperation, no place, no publisher, (1972).

Cant, Anna. “"The Land For Those Who Work It': A visual Analysis of Agrarian Reform Posters in Velasco's Peru." Journal of Latin American Studies 44.1 (2012): 1-37. doi: 10.1017/S002216X11001106. 
Contreras C., Pablo. "Struggles for Modernization: Peru and the United States, 19611968." PhD. Diss., University of Connecticut, 2010. ProQuest, Dissertations and Theses.

http://proxy.library.carleton.ca/login?url=http://search.proquest.com. proxy.library.carleton.ca/docview/896626324?accountid $=9894$

Cooper, Frederick and Packard, Randall (eds.). International Development and the Social Sciences: Essays on the History and Politics of Knowledge. Los Angeles, CA: University of California Press, 1997.

Coronado, Jorge. The Andes Imagined: Indigenismo, Society, and Modernity. Pittsburgh, PA: University of Pittsburgh Press, 2009.

Coupal, François Praline. "Contradictions of the Peruvian Experiment: Through the Optic of Agrarian Reform and Agricultural Cooperatives." Master of Arts Thesis, Carleton University, Ottawa, ON 1984.

Eye on the UN. "Political Alliances within the UN: Inter-governmental groups and alliances operating within the UN system." Accessed May 14, 2012, from: http://www.eyeontheun.org/view.asp?p=55\&l=11

Foreign Affairs and International Trade Canada. "1945-1957 A Divided World," Canada and the World: A History of Canadian Foreign Policy. Last modified September 9, 2011. Accessed July 9, 2012 from: http://www.international.gc.ca/history-histoire/world-monde/19451957.aspx?lang $=$ eng \& view $=\mathrm{d}$

Foreign Affairs and International Trade Canada. "The Organization of American States (OAS)." Last modified June 1, 2012. Accessed July 10, 2012 from: http://www.oas.org/en/

Granatstein, J.L. and Bothwell, Robert. Pirouette: Pierre Trudeau and Canadian Foreign Policy. Toronto, ON: University of Toronto Press, 1990.

Gorriti Ellenbogen, Gustavo. The Shining Path: a history of the millenarian war in Peru. Chapel Hill, N.C.: University of North Carolina Press, 1999.

Guevara, Che. "Case Studies: Peru." In Guerrilla Warfare. $3^{\text {rd }}$ ed. Revised by Brian Loveman, and Thomas Jr. Davies. Translated by J.P. Morray. Lincoln, Nebraska: University of Nebraska Press. 
Heilman P., Jaymie. "We Will No Longer Be Servile: 'Aprismo' in 1930s Ayacucho." Journal of Latin American Studies 38.3 (2006): 491-518. http://www.jstor.org/stable/3875869Jennings, Michael. "Surrogates of the State? Non-Governmental Organisations and Development in Tanzania in the 1960s and 1970." African Studies Seminar. Centre for Development Studies, Swansea University, (2006). Accessed January 25, 2011, from: http://www.ascleiden.nl/Pdf/paper-jennings.pdf.

Hobsbawn, E. J. E. “A Case of Neo-Feudalism: La Convención, Peru." Journal of Latin American Studies. 1.1 (1969): 31-50. doi http://dx.doi.org/10.1017/S0022216X00000043

Human Rights Watch: Peru. "Country Summary." January 2012. Accessed September 21, 2012 from: http://www.hrw.org/world-report-2012/peru.

Johnson, Joshua. "From Cuba to Bolivia." Innovations: A Journal of Politics vol. 6, (2006): 26-32. Accessed June 27, 2012, from:

https://afe.ucalgary.ca/innovations/files/innovations/Johnson\%20Cuba\%20to $\% 20$ Bolivia.pdf

Kinsman, Jeremy. "Who is My Neighbour? Trudeau and Foreign Policy." International Journal 57.1 (2001/2001): 55-77. Accessed July 11, 2012 from: http://www.jstor.org/stable/40203633

Koc-Menard, Sergio. "Fragmented sovereignty: Why Sendero Luminoso consolidated in some regions of Peru but not in others." Studies in Conflict and Terrorism 30.2 (2007). doi 10.1080/10576100600695770

Korovkin, Tanya. "The Politics of Agricultural Cooperativism: Peru, 1969-1983." PhD. Diss., York University, 1986, Toronto, ON. ProQuest, Dissertations and Theses. http://search.proquest.com/docview/250094723?accountid=9894

Korovkin, Tanya. "Politics of Agricultural Co-Operativism: Peru, 1969-1983." Vancouver, B.C.: University of British Columbia Press, (1990). Accessed January 29, 2011, from: http://www.questia.com/PM.qst?a=o\&d=29330151\#.

Levitt, Barry Steven. "Continuity and Change in Peru's Political Parties, 1985-2000." Paper presented at Congress of the Latin American Studies Association (LASA). Miami Florida, 2000.

Malone, David. "Foreign Policy Reviews Reconsidered." International Journal 56.4 (2001): 555-578. Accessed July 7, 2012 from: http://www.jstor.org/stable/40203604.

Marxist Internet Archive. Juan Velasco Alvarado, n.d. Accessed June 10, 2012 from: http://www.marxists.org/espanol/velasco/index.htm 
Masterson M., Daniel. Militarism and Politics in Latin America: Peru from Sánchez Cerro to Sendero Luminoso. Westport, U.S.: Greenwood Press, 1991.

Mayer, Enrique. "Democracy in the workplace: Agrarian Cooperatives in the Peruvian Agrarian Reform (Ugly Stories remembered)." Paper prepared for a Conference on The Roots and Future of the Democratic Tradition in Latin America, Yale University, December 2011. Accessed July 15, 2012 from: http://www.yale.edu/macmillan/lais/democratictradition/papers/MayerDemocracyinworkplace.PDF

Mayer, Enrique. Ugly Stories of the Peruvian Agrarian Reform. Durham, N.C.: Duke University Press, 2009.

Morrison, David R. Aid and Ebb Tide, A History of CIDA and Canadian Development Assistance. Waterloo, ON: Wilfrid Laurier University Press in association with The North-South Institute, 1998.

Munck, Rolando. Revolutionary Trends in Latin America. Centre for Developing Area Studies, Occasional Monograph Series 17. Montreal, QC: McGill University, 1984.

Navarro, Paul. "A Maoist Counterpoint: Peruvian Maoism Beyond Sendero Luminoso." Latin American Perspectives 37.1 (2010): 152-171. doi: $10.1177 / 0094582 \times 09351716$.

Palmer, Bryan D. Canada's 1960s: The Ironies of Identity in a Rebellious Era. Toronto, ON: University of Toronto Press Incorporated 2009.

Payne, Arnold. The Peruvian Coup D'Etat of 1962: The Overthrow of Manuel Prado. Political Studies Series, no. 5. Washington, D.C.: Institute for the Comparative Study of Political Systems, 1968.

Pribilsky, Jason. "Development and the 'Indian Problem' in the Cold War Andes: Indigenismo, Science, and Modernization in the Making of the Cornell-Peru Project at Vicos." The Journal of the Society for Historians of American Foreign Relations, 33.3, (2009): 405-426.

Público. "Cajamarca quiere agua, no oro." July $8^{\text {th }}, 2012$. Accessed July 27, 2012 from: http://www.publico.es/internacional/439388/cajamarca-quiere-agua-nooro My translation.

Rochlin, James. Discovering the Americas: The Evolution of Canadian Foreign Policy Toward Latin America. Vancouver BC: UBC Press, 1994. 
Seligmann J., Linda. Between Reform \& Revolution: Political Struggles in the Peruvian Andes. Stanford, California: Stanford University Press, 1995.

Suri, Jeremi. "Non-Governmental Organizations and Non-State Actors." In Palgrave Advances in International History, edited by Patrick Finney. New York: Palgrave MacMillan, 2005.

The Avalon Project. Manifesto of the Communist Party : III. Socialist and Communist Literature. Yale Law School, Lillian Goldman Law Library. Accessed July 8, 2012 from: http://avalon.law.yale.edu/19th_century/manthree.asp

Spanish Central. "Peru: Country Page," (n.d.). Accessed May $18^{\text {th }} 2012$ from: http://spanish-central.com/Main/Countries/Peru/Peru.html

Trotsky, Leon. "Dual Power," in History of the Russian Revolution. Translated by Max Eastman. London: Victor Gollancz Limited, 1965.

Trotsky, Leon. "The Theory of Permanent Revolution." Ed. Isaac Deutscher in The Age of Permanent Revolution. New York, NY: Dell, 1964.

United Nations Conference on Trade and Development. "A Brief History of UNCTAD." Last modified 2012. Accessed July 11, 2012, from: http://unctad.org/en/Pages/About\%20UNCTAD/A-Brief-History-ofUNCTAD.aspx.

Vanden E., Harry E. "Mariátegui: Marxismo, Comunismo, and Other Bibliographic Notes." Latin American Research Review 14.3 (1979): 61-86. http://proxy.library.carleton.ca/login?url=http://search.proquest.com.proxy.lib rary.carleton.ca/docview/748473682?accountid $=9894$

Whitaker, Reg and Hewitt, Steve. Canada and the Cold War. Toronto, ON: James Lorimer \& Company Ltd., 2003. 